\title{
TRANSPIRATION BY OIL PALM AND RUBBER PLANTATIONS: REFINING METHODS AND DELINEATING DIFFERENCES
}

\author{
Dissertation \\ zur Erlangung des akademischen Grades Doctor of Philosophy (PhD) \\ der Fakultät für Forstwissenschaften und Waldökologie \\ der Georg-August-Universität Göttingen
}

\author{
vorgelegt von \\ Furong Niu \\ geboren in Gansu, China
}

Göttingen, 2016 
PhD advisor: Prof. Dr. Dirk Hölscher

1. Gutachter: Prof. Dr. Dirk Hölscher

2. Gutachter: Prof. Dr. Alexander Knohl

3. Gutachter: Prof. Dr. Holger Kreft

Tag der mündlichen Prüfung: 09. September 2016 


\section{TABLE OF CONTENTS}

ABSTRACT ........................................................................................................................................ V

ZUSAMMENFASSUNG......................................................................................................................... VII

OVERVIEW PUBLICATIONS............................................................................................................XI

CHAPTER 1. GENERAL INTRODUCTION ........................................................................................ 1

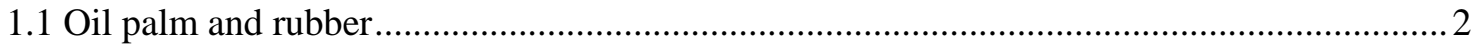

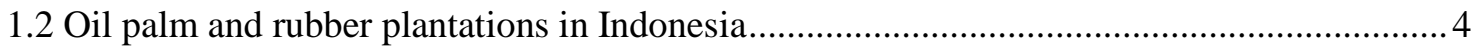

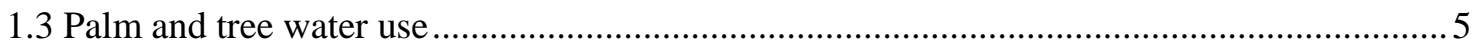

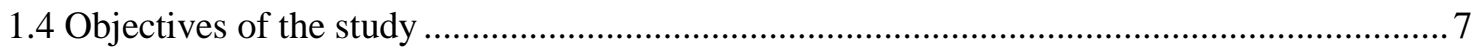

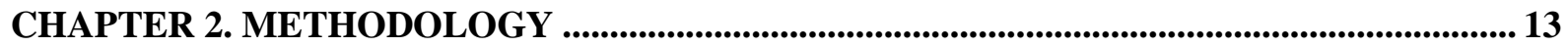

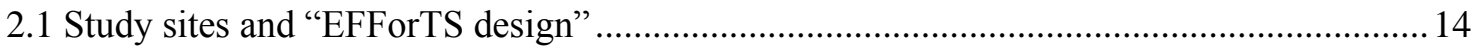

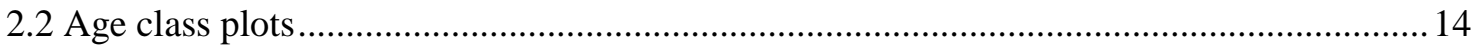

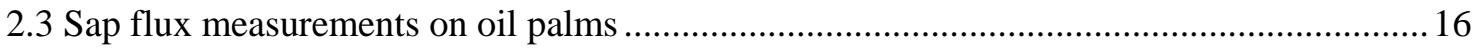

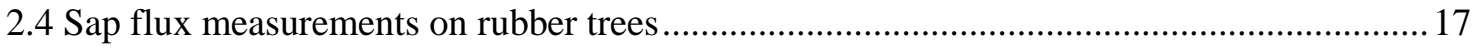

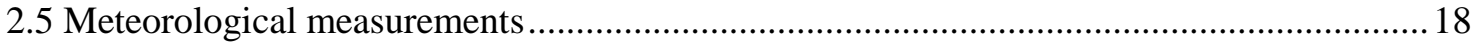

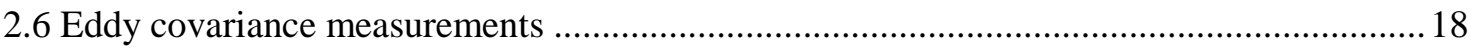

CHAPTER 3. OIL PALM WATER USE: CALIBRATION OF A SAP FLUX METHOD AND A FIELD MEASUREMENT SCHEME

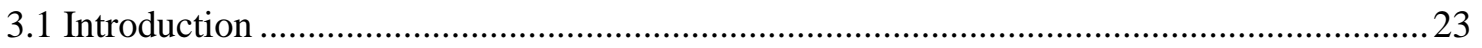

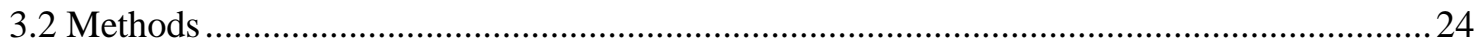

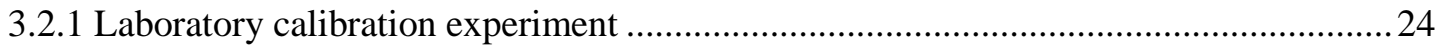

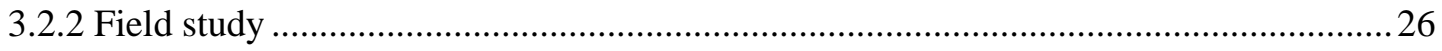

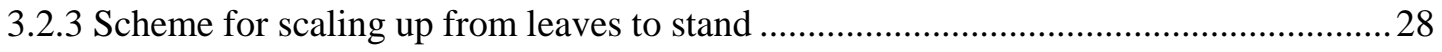

3.2.4 Estimation errors associated with sample size …..........................................................2 29

3.2.5 Analyzing the environmental drivers of leaf water use ……......................................... 30

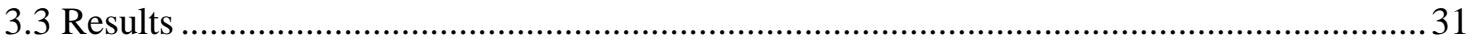

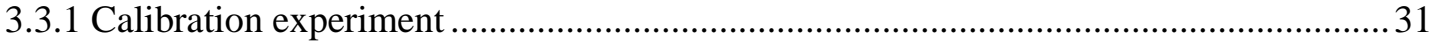

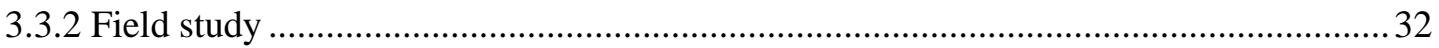

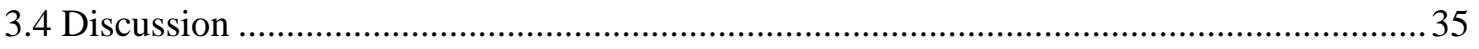

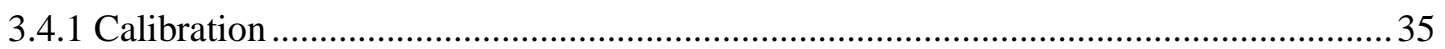

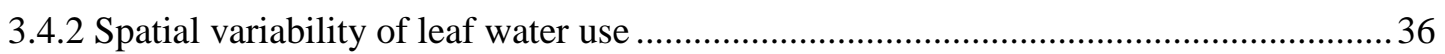

3.4.3 Error margins of stand transpiration and "optimal" sample sizes ...................................37

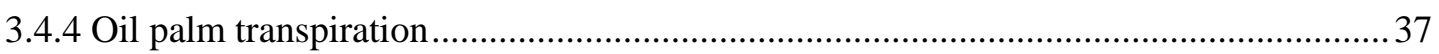

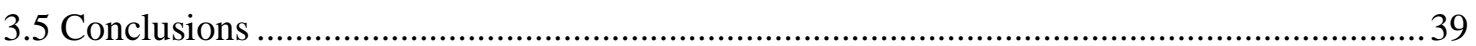

CHAPTER 4. TRANSPIRATION IN AN OIL PALM LANDSCAPE: EFFECTS OF PALM 
4.1 Introduction.

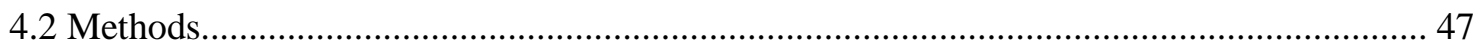

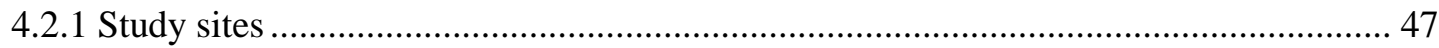

4.2.2 Sap flux measurements and transpiration ..................................................... 48

4.2.3 Stand structural characteristics.................................................................. 48

4.2.4 Eddy covariance measurements and evapotranspiration.................................... 49

4.2.5 Environmental drivers of oil palm water use .............................................. 50

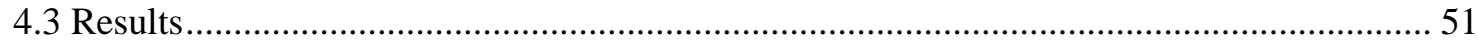

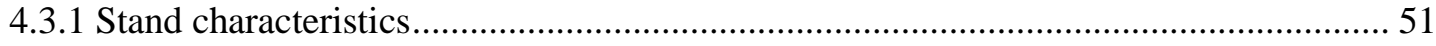

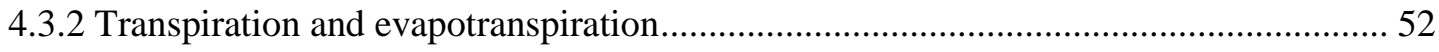

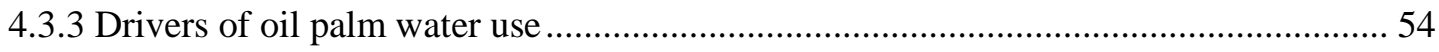

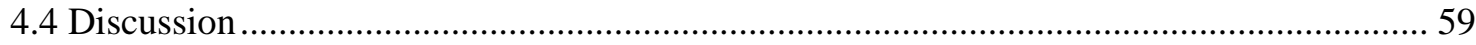

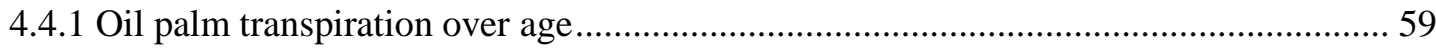

4.4.2 Evapotranspiration and the contribution of transpiration..................................... 60

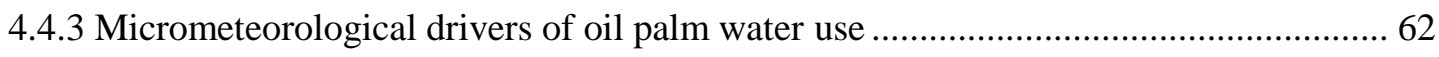

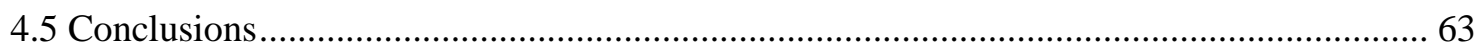

CHAPTER 5. RUBBER TREE TRANSPIRATION IN THE LOWLANDS OF SUMATRA .....75

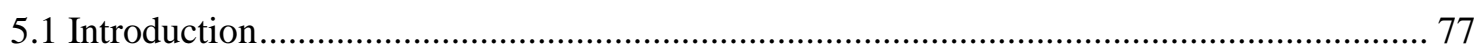

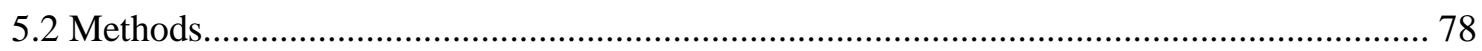

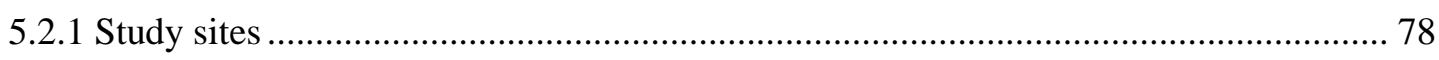

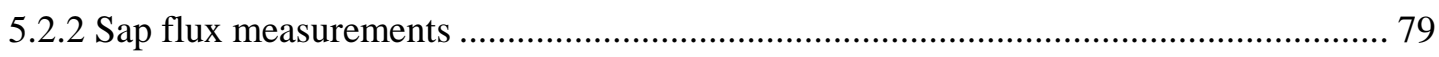

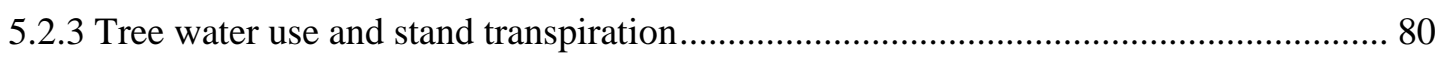

5.2.4 Environmental and phenological monitoring ................................................... 81

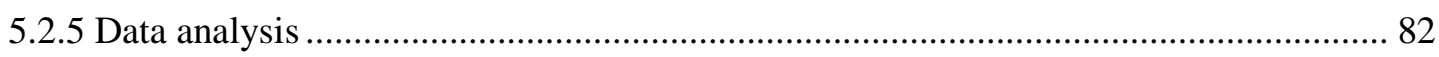

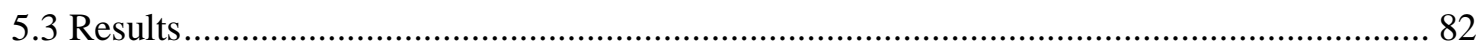

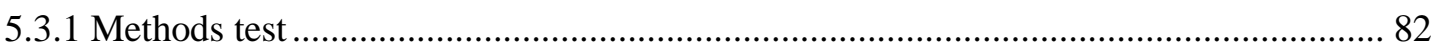

5.3.2 Patterns in rubber tree water use ................................................................. 84

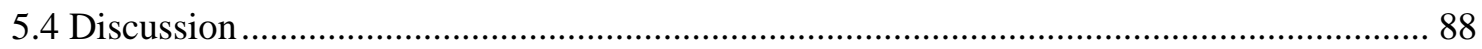

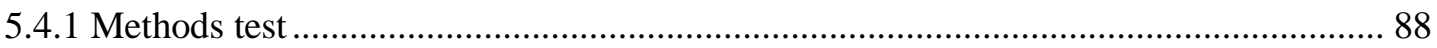

5.4.2 Patterns in rubber tree water use ................................................................. 88

5.4.3 Comparison with other rubber and oil palm transpiration data.............................. 90

CHAPTER 6. SYNTHESIS.....................................................................................................97

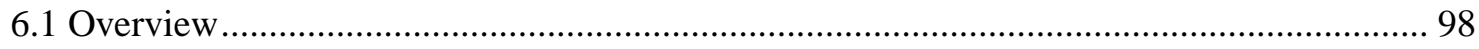

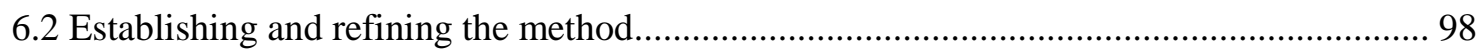

6.3 Differences in oil palm and rubber tree water use .............................................. 99

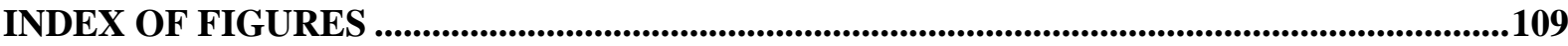




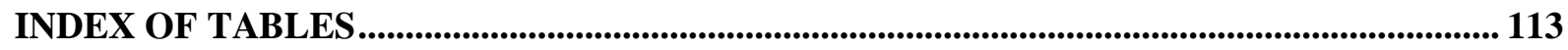

ACKNOWLEDGEMENTS ....................................................................................................................... 115

DECLARATION OF HONOR ............................................................................................................... 117

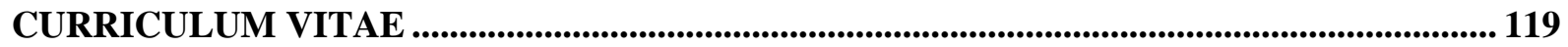




\section{ABSTRACT}

Oil palm (Elaeis guineensis Jacq.) and rubber (Hevea brasiliensis Müll. Arg.) plantations cover large areas in tropical regions and may still expand further. In contrast, the area covered by natural forests has strongly declined. From environmental perspectives, this raises concerns not only with respect to biodiversity but also regarding the integrity of the hydrological cycle including potential changes in transpiration. For rubber plantations, high evapotranspiration rates were reported from mainland Asia and it was indicated that rubber tree transpiration responds sensitively to dynamics in environmental drivers. Prior to our studies, little scientifically based information was available for oil palm. The objective of this study was to test and if necessary adjust a sap flux measurement technique for the two species, to analyze influences of plantation age and environmental drivers on oil palm and rubber tree transpiration and to delineate differences between the two plantation types. The study was implemented in the lowlands of Sumatra, Indonesia. Methods include lab experiments with thermal dissipation probes and gravimetric reference measurements, three different sap flux methods applied in the field (thermal dissipation probes, heat field deformation and stem heat balance), and a monitoring of sap flux on a total of 25 plots in lowland Sumatra.

Thus far, sap flux measurements had not been applied to oil palms. We first calibrated the thermal dissipation probe method (TDP) after Granier (1985) and tested a field sampling scheme. The probes were inserted into leaf petioles, as most likely the density of vessels is higher and vessels are distributed more homogenously than in the trunk. In the laboratory, we tested this set-up against gravimetric measurements and derived new, oil palm specific parameters for the calibration equation. In the field, in a 12-year-old plantation, 56 leaves on 10 palms were equipped with TDP sensors. We did not find significant influences of a series of studied variables and thus took an un-stratified approach to determine an appropriate sampling scheme to estimate stand transpiration rates. The relative standard error of the mean was used as a measure for the potential estimation error of stand transpiration associated with sample size. It was $14 \%$ for a sample size of 13 leaves to determine the average leaf water use and four palms to determine the average number of leaves per palm. Increasing these sample sizes only led to minor further decreases of the relative standard errors of the mean.

Oil palm transpiration rates were then monitored on 15 on-farm plots using this sap flux technique and sampling scheme in conjunction with eddy covariance measurements at two sites. Oil palm water use and transpiration increased from two to about eight-year old plantations and then leveled off up to an age of 22 years. Among medium-aged, 10 to 18 years old plantations, substantial spatial heterogeneity was found, with the highest oil palm stand transpiration rates (2.5 $\mathrm{mm} \mathrm{d}^{-1}$ ) in a highly intensively managed plantation being as high as or even higher than 
transpiration of forests in the same region. However, average transpiration across several smallholder properties was much lower. It was also indicated that the temporal dynamics of transpiration in oil palm are "buffered", which means that day-to-day transpiration rates fluctuate much less than micrometeorological drivers.

In rubber trees, lab experiments did not indicate significant differences to the original calibration equation. In a field trial, the TDP sensors combined with heat field deformation sensors resulted in tree water use rates very similar to those obtained by the independent stem heat balance method. We monitored sap flux on 10 on-farm plots in mono-cultural rubber plantations between 2 and 17 years old. Tree water use increased from two to about eight-year old plantations and then leveled off. We observed pronounced differences in the relation tree diameter to water use: it increased steeply in young plantations up to an age of eight years; in 14 and $16 \mathrm{yr}$ old plantations the increase was much less pronounced. In the older plantations, sap flux densities decreased with increasing tree diameter, while the opposite was true for the younger plantations. Rubber tree transpiration showed a pronounced seasonality due to partial leaf shedding. Overall, the magnitude of transpiration was substantially lower than previously reported for rubber plantations on the Asian mainland. Potential reasons include differences in methods, climate and management. Data from the Asian mainland were mainly derived by the eddy covariance approach, which often results in estimates higher than those from sap flux studies. Differences in sap flux derived rates from both regions are much less pronounced. The climate in is more continental on the Asian mainland, and maritime in lowland Sumatra. Additionally, the studies in mainland Asia were conducted on well-managed experimental farms and with modern rubber tree clones. Our study was conducted on small-holder properties in the hinterland of Jambi, which are less sophisticated and intensively managed, and an age-related decline of water use rates was observed.

Oil palm and rubber plantations differed from each other mainly in the magnitude of transpiration, which is on average by ca. $30 \%$ higher in oil palm, and regarding the seasonality in rubber plantations as induced by periodic leaf-shedding. These differences between species and the suggestions made regarding climatic and management related influences on transpiration may be of interest to eco-hydrological assessments of post-forest tropical plantation landscapes. 


\section{ZUSAMMENFASSUNG}

Ölpalm (Elaeis guineensis Jacq.) und Kautschuk (Hevea brasiliensis Müll. Arg.) Plantagen bedecken in den Tropen weite Flächen, die wohl auch weiterhin an Größe zunehmen werden. Andererseits hat dort die Fläche die von Naturwäldern bedeckt wird drastisch abgenommen. Aus ökologischer Sicht ist dies nicht nur hinsichtlich des Biodiversitätsverlustes problematisch, sondern etwa auch hinsichtlich potentieller Konsequenzen für die Integrität von Ökosystemwasserkreisläufen, etwa aufgrund von Veränderungen der Bestandestranspirationsraten. Vorausgegangene Studien vom asiatischen Festland wiesen auf sehr hohe Evapotranspirationsraten von Kautschukplantagen sowie auf ein relativ sensitives Verhalten auf Schwankungen mikrometereologischer Bedingungen hin. Unseren Wissens nach waren vor unseren Studien keine solchen Information hinsichtlich des Wassernutzungsverhaltens von Ölpalmen verfügbar. Die Zielsetzung unserer Studien umfasste somit auch, eine häufig angewandte Saftflussmessungsmethode an Ölpalme und Kautschuk zu testen und nötigenfalls entsprechend anzupassen. Außerdem wurden die Effekte von Plantagenalter und von Veränderungen mikrometereologischer Bedingungen auf die Transpirationsraten der beiden Plantagentypen untersucht, auch hinsichtlich einer schlusslegenden differenzierten Betrachtung der Gemeinsamkeiten und Unterschiede der Wassernutzungscharakteristika von Ölpalm- und Kautschukplantagen. Die Studien wurden in der Tieflandregion Sumatras (Indonesien) durchgeführt. Methodische Ansätze umfassten Laborexperimente mit sog. ,thermal dissipation probe“ (TDP) Saftflusssensoren, die Feldanwendung von drei verschiedenen Saftflussmesstechniken (TDP, „heat field deformation“ HFD und „stem heat balance“ SHB) und eine 25 Versuchsflächen umfassende Saftflussmesskampagne im Tiefland von Sumatra.

Vor unseren Studien waren unseres Wissens nach noch keine Saftflussmessungen an Ölpalmen erfolgt. Wir kalibrierten somit zuerst die TDP Methode nach Granier (1985) für Messungen an Ölpalmen und entwickelten dann ein passendes Probedesign für eine Saftflussmesskampagne im Feld. Wir brachten die Saftflusssensoren an den Blattstielen von Ölpalmblättern an, da es wahrscheinlich schien, dass dort eine höhere Leitbündeldichte sowie eine gleichmässigere Verteilung der Bündel anzutreffen wäre als etwa im Stamm. Im Labor testeten wir dieses System unter Zuhilfenahme gravimetrischer Vergleichsmessungen und leiteten neue, ölpalmspezifische Parameter für Granier's Saftflussformel her. Im Feld statteten wir in einer 12-jährigen Ölpalmplantage 56 Blätter an 10 verschiedenen Palmen mit TDP Sensoren aus. Da keines von zahlreichen erfassten Blattcharakteristica signifikante Auswirkungen auf die Blattwassernutzungsraten zu haben schien, entschieden wir uns für ein unstratifiziertes Probedesign für die Schätzung der Bestandestranspirationsraten. Wir nahmen den relativen Standardfehler des Mittelwerts als Maß für den potentiellen Schätzfehler der ermittelten Bestandes- 
transpirationsraten, welcher auf den limitierten Stichprobenumfang zurückzuführen ist. Für einen Stichprobenumfang von 13 Blättern zur Ermittlung der durchschnittlichen Blattwassernutzungsraten, und von vier Palmen zur Ermittlung der durchschnittlichen Anzahl von Blättern pro Palme, betrug er 14\%. Eine weitere Erhöhung dieser Stichprobenumfänge führte zu nur marginal besseren Ölpalmbestandestranspirationsratenschätzungen.

Als folgenden Schritt wandten wir das entwickelte TDP Saftflussstichprobendesign auf 15 Ölpalmversuchsflächen an um Bestandestranspirationsraten zu ermitteln; auf zwei dieser Flächen erfolgten zudem zeitgleich Eddy-Kovarianz-Messungen. Palmen- und Bestandetranspirationsraten erhöhten sich sehr stark von 2-jährigen zu 8-jährigen Ölpalmplantagen, blieben dann aber mit weiter fortschreitendem Plantagenalter (bis zu 22 Jahren) relativ konstant. Zwischen den mittelalten Plantagen (10 bis 18 Jahre) zeigte sich ausgeprägte räumliche Heterogenität. Die Plantage mit der höchsten ermittelten Bestandestranspirationsrate $\left(2.5 \mathrm{~mm} \mathrm{~d}^{-1}\right)$ war eine intensiv bewirtschaftete, kommerzielle Plantage, derern Transpirationsrate sogar die von Naturwäldern in der Studienregion überstieg. In den untersuchten Plantagen von Kleinbauern waren die ermittelten Transpirationsraten hingegen geringer. Wir fanden weiterhin Hinweise auf ein „abgepuffertes“ Verhalten der Ölpalmtranspiration: deren Fluktuation von Tag zu Tag war weitaus geringer als die Fluktuationen ausschlaggebender mikrometereologischer Variablen.

Im Gegensatz zu den Experimenten an Ölpalmblättern wiesen die Laborexperimente an Kautschukstammteilen auf keine signifikanten Unterschiede zur der ursprünglichen Granier'schen Saftflussformel hin. In Feldversuchen erzielten wir bei der Kombination von TDP Sensoren und HFD Sensoren ähnliche Ergebnisse wie bei Messungen mit SHB Sensoren. Die Feldsaftflussmesskampagne umfasste 10 Kautschuk Monokulturen, die zwischen 2 und 17 Jahren alt waren. Ähnlich wie zuvor in Ölpalmplantagen fanden wir auch für Kautschuk zunächst stark ansteigende Wassernutzungsraten (von etwa 2- bishin zu 8-jährigen Plantagen), die dann jedoch mit zunehmendem Plantagenalter nicht mehr weiter anstiegen. Es gab deutliche Unterschiede zwischen jungen (bis 8 Jahre) und alten (14-16 Jahre) Kautschukplantagen hinsichlich der Durchmesser-Wassernutzungs-Beziehung: wir verzeichneten einen starken linearen Anstieg der Baumwassernutzungsraten mit zunehmendem Stammdurchmesser in jungen Plantagen und einen wesentlich moderateren Anstieg in den älteren Plantagen. Dies war auf eine positive lineare Beziehung der Saftflussdichte mit dem Stammdurchmesser in jungen Plantagen zurückzuführen, während die Beziehung in älteren Plantagen negativ war. Die jährliche Dynamik der Kautschuktranspirationsraten war stark saisonal, geprägt von Phasen teilweisen Blattwurfs in niederschlagsärmeren Perioden. Die Magnitude der ermittelten Bestandestranspirationsraten war deutlich niedriger als in vorhergegangenen Kautschukstudien auf dem asiatischen Festland, was auf methodische, klimatische oder management-bezogene Unterschiede zurückzuführen sein könnte. So basieren etliche Festlandstuden auf der Eddy-Kovarianz-Methode, die oft höhere 
Schätzwerte liefert als beispielsweise Saftflussstudien. Letztere ergeben auch für das Festland niedrigere und somit zu unserer Studie vergleichbarere Schätzungen der Wassernutzungsraten von Kautschukplantagen. Des weiteren gibt es ausgeprägte klimatische Unterschiede zwischen Festland und unserer maritimen Studienregion. Ein weiterer Faktor könnte auch professionelles Plantagenmanagement auf dem Festland sein, da es sich im Gegensatz zu den oft wenig intensiv bewirtschafteten Kleinbauernflächen in unserer Studie dort teils um experimentelle Farmen handelt, in denen beispielsweise modernere Klonvarietäten gepflanzt werden.

Zusammenfassend kann gesagt werden, dass sich Ölpalm- und Kautschukplantagen ökohydrologisch gesehen vor allem hinsächlich der Magnitude der Bestandestranspirationsraten unterscheiden. Diese liegt in Ölpalmpantagen etwa 30\% höher. Ein weiterer deutlicher Unterschied ist die durch den periodischen Blattabwurf sehr ausgeprägte Saisonalität der Bestandestranspiration in Kautschukplantagen. Solche Unterschiede, sowie die aufgezeigten potentiellen klimatischen und management-bezogenen Effekte auf die Bestandestranspiration von Ölpalm und Kautschukplantagen, könnten u.a. in Hinblick auf öko-hydrologische Assessments tropischer Post-Entwaldungs-Landschaften von Interesse sein. 


\section{OVERVIEW PUBLICATIONS}

\section{Publications given as chapters of this dissertation}

\section{Chapter 3:}

Oil palm water use: a calibration and a field measurement scheme

Niu, F. ${ }^{* \dagger}$, Röll, A.., Hardanto, A., Meijide, A., Hendrayanto, Hölscher, D.

Published in Tree Physiology (2015) 35: 563-573, doi: 10.1093/treephys/tpv013.

* Equal contribution

$\dagger$ Corresponding author

The study was carried out within the framework of the joint research project "Ecological and Socioeconomic Functions of Tropical Lowland Rainforest Transformation Systems (Sumatra, Indonesia) (EFForTS)". Furong Niu conducted the laboratory calibration, maintained the field installations and contributed to the data collection. Furong Niu extensively contributed to data analyses and manuscript preparation including creating figures and manuscript writing.

\section{Chapter 4:}

\section{Transpiration in an oil palm landscape: effects of palm age}

Röll, A. ${ }^{* \dagger}$, Niu, F. , Meijide, A., Hardanto, A., Hendrayanto, Knohl, A., Hölscher, D.

Published in Biogeosciences (2015) 12: 5619-5633, doi: 10.5194/bg-12-5619-2015.

* Equal contribution

$\uparrow$ Corresponding author

The study was developed within the framework of the joint research project "EFForTS". Furong Niu conducted setup and maintenance of the field installations and data collection in six of the 15 studied plots and participated in setup and maintenance of the other nine study plots. Furong Niu contributed to data analyses and manuscript preparation including creating figures and tables, and manuscript writing. 


\section{Chapter 5:}

\section{Rubber tree transpiration in the lowlands of Sumatra}

Niu, F. ${ }^{* \dagger}$, Röll, A. , Meijide, A., Hendrayanto, Hölscher, D.

Complete draft.

* Equal contribution

$\dagger$ Corresponding author

The study was developed within the framework of the joint research project "EFForTS". Furong Niu conducted the laboratory calibration, ran the two different sap flux approaches in the field, installed and maintained one young rubber plot and contributed to the sap flux measurements in the other rubber plots. Furong Niu analyzed data from the lab experiment and the three sap flux methods, from the two young rubber plots, and contributed to the analyses of the other eight rubber plots. Furong Niu wrote the first draft of the manuscript and coordinates its further development.

Three other manuscripts to which Furong Niu contributes as a co-author and which are based on studies in the joint research project "EFForTS" are in advanced stages. 
CHAPTER 1

\section{GENERAL INTRODUCTION}




\subsection{Oil palm and rubber}

Oil palm (Elaeis guineensis Jacq.) originates from the West African rainforest regions. As one of the most rapidly expanding oil crops, it has spread to other tropical regions over the last decades, particularly in Southeast Asia, e.g. in Indonesia and Malaysia (Cater et al., 2007; USDA, 2007; Carr, 2011; FAOSTAT, 2016). The global total cultivated area of oil palm has increased from 6 million hectares with 60 million tons production of fruit in 1990 to 19 million hectares with 274 million tons production in 2014, which represents about 3-fold and 4.5-fold increases in cultivated area and production, respectively. Combined, the plantation area of Indonesia and Malaysia account for $65 \%$ and $81 \%$ of the global total cultivated area and annual production in 2014, respectively (FAOSTAT, 2016; Figure 1.1). The oil extracted from the fruits of oil palms has diverse usages; it can e.g. be used as edible oil for cooking and as a food additive, and it can also be found in a variety of non-edible products such as cosmetics, industrial lubricants and bio-fuels (Crabbe et al., 2001; Edem, 2002; Corley and Tinker, 2003; Carr, 2011). Its yield per unit of land is the highest among all known oil crops (Corley and Tinker, 2003), e.g. six times as high as soybean, eight times as high as rapeseed, and ten times as high as sunflower seed (FAOSTAT, 2016). The global expansion of oil palm plantations is mainly driven by the rising demanding for an economical vegetable oil for human consumption, and a further continuing growth of the palm oil market has been projected (Cater et al., 2007; USDA, 2007; Corley, 2009).

In many tropical regions, agricultural expansion as e.g. oil palm takes place mainly at the cost of remaining natural rainforests (Curran et al., 2004; Fitzherbert et al., 2008; DeFries et al., 2010; Margono et al., 2014). From 1990-2006, at least 55\% of the oil palm expansion in Southeast Asia was believed to be at the expense of natural forests (Koh and Wilcove, 2008), which could potentially induce losses of ecosystem functions such as loss of biodiversity (Fitzherbert et al., 2008; Koh and Wilcove, 2008, Wilcove and Koh, 2010; Foster et al., 2011; Barnes et al., 2014), high emission of greenhouse gases (Carlson et al., 2012, 2013; Ramdani and Hino, 2013), negative effects on soil carbon and nitrogen cycling (Allen et al., 2015; Van Straaten et al., 2015; Guillaume et al., 2015) and high soil erosion (Guillaume et al., 2015). Concerns about periodic water scarcity during dry seasons have also been raised for conversions of rainforest to oil palm monocultures (Merten et al., 2016).

The rubber tree (Hevea brasiliensis Muell. Arg.), a tree indigenous to the Amazon rainforest, is another important cash crop and has a long history of cultivation in tropical regions (Carr, 2012). The latex extracted from the tree trunk is an important source of natural rubber, which is commonly used in the manufacture of tires (Carr, 2012; Li and Fox, 2012). The rubber tree is vastly planted in the humid tropical regions along the equatorial zone (Priyadarshan et al., 2005), particularly in Southeast Asia, with a focus in Thailand, Indonesia, and Malaysia, which account 
for $97 \%$ of the total global production (Carr, 2012; FAOSTAT, 2016). More recently it has also been expanding to the drier and colder environments e.g. on the montane mainland of Southeast Asia, with new breeding clones that are well established in e.g. Southern China and Northern Thailand, which are rather non-traditional planting areas for the rubber tree (Priyadarshan et al., 2005; Qiu, 2009; Ziegler et al., 2009; Li and Fox, 2012). In the traditional rubber planting regions in Southeast Asia, such as in Indonesia, rubber plantations are sometimes more of an agroforestry system than monocultures, e.g. so-called "Jungle Rubber" (Gouyon et al., 1993). This agroforestry system has succeeded in maintaining forest functions to a certain extent while at the same time producing rubber latex and other timber and non-timber forest products (Gouyon et al., 1993; Feintrenie and Levang, 2009; Lehébel-Péron et al., 2011). However, more recently, jungle rubber is continuously being replaced by more productive rubber monocultures, driven by the rising price and great demanding of natural rubber on the global markets (Feintrenie and Levang, 2009). The expansion of rubber plantations on the mainland of Southeast Asia has been reported to trigger negative effects on local ecosystems, which, as in the case of oil palm expansion, include the loss of biodiversity (Li et al., 2007; Fu et al., 2010; Ahrends et al., 2015; WarrenThomas et al., 2015), reductions in carbon stock (de Blécourt et al., 2013; Li et al., 2008) and high evaportranspiration rates of rubber plantations (Guardiola-Claramonte et al., 2010; Tan et al., 2011; Giambelluca et al., 2016). However, regardless of the strong expansion of rubber monocultures e.g. in Indonesia since the 1970s to the present (Feintrenie and Levang, 2009), effects of this expansion on the hydrological cycle have received relatively little scientific attention.
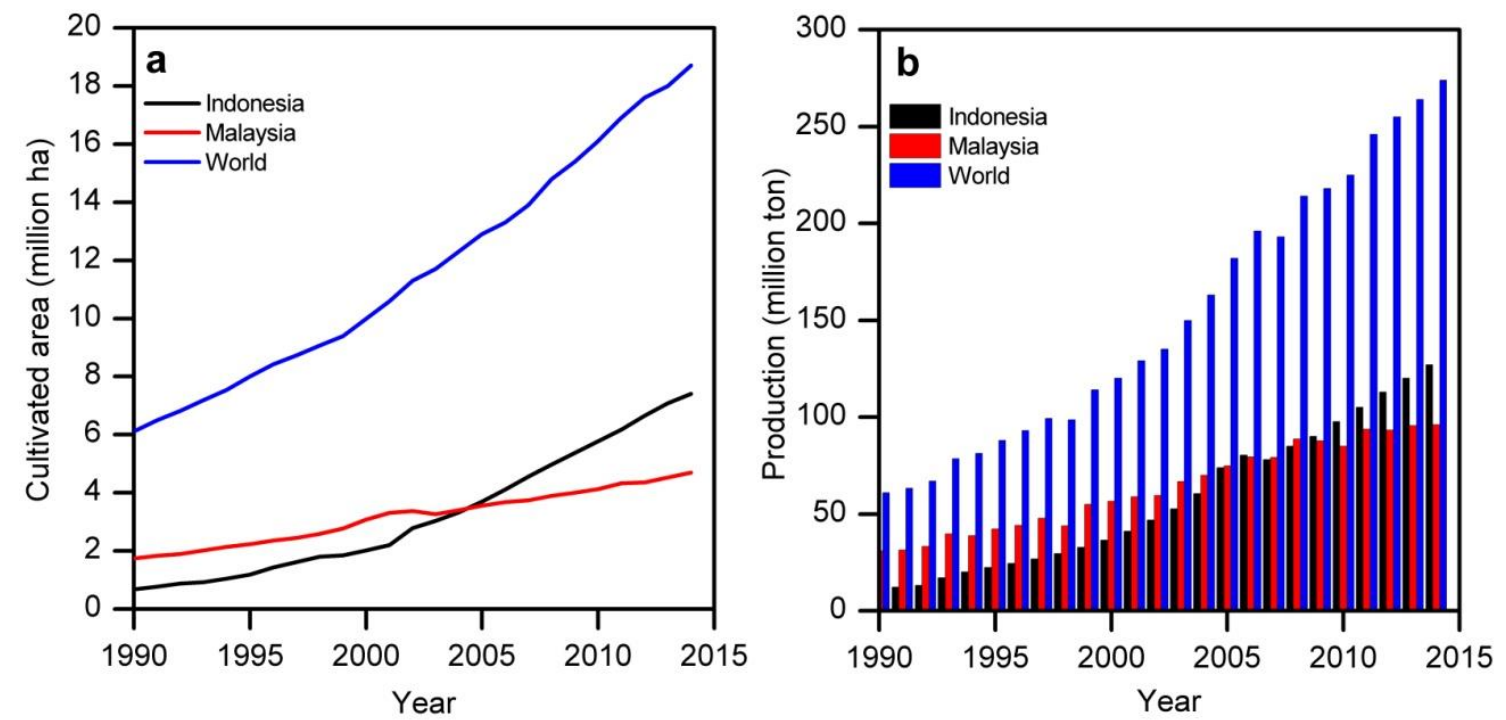

Figure 1.1 The cultivated area (a) and production of fruit (b) of oil palm plantations in Indonesia, Malaysia, and the world from 1990 to 2014. Data are from FAOSTAT (2016). 


\subsection{Oil palm and rubber plantations in Indonesia}

Over recent decades, oil palm plantations have drastically increased in area in Indonesia, mainly in Sumatra, Kalimantan and more recently also in parts of Papua (Figure 1.2) (Casson, 2000; Sheil et al., 2009), which in consequence suffered extensive losses of their primary forest area (Margono et al., 2014). Today, Indonesia is the largest oil palm producing country in the world, having surpassed Malaysia in 2009 with regard to total palm oil production (FAOSTAT, 2016). In 2014, the total cultivated area under oil palm plantations in Indonesia was ca. 7.4 million hectares, including both large oil palm concessions and small-holder plantations (Feintrenie et al., 2010). The production of oil palm fruit was around 127 million tons, which accounts for $46 \%$ of the world's total (FAOSTAT, 2016). Among all Indonesian islands, Sumatra is by far the biggest producer, with about $80 \%$ of the annual national total production in 2008 (USDA, 2009), and with the cultivated area of oil palm plantations accounting for $76 \%$ of the total area in Indonesia (IPOC, 2006; Sheil et al., 2009). Furthermore, considering the high global demand for palm oil for edible products and biofuel feedstock, the current expansion of oil palm plantations is likely to continue (Cater et al., 2007; Koh and Ghazoul, 2008; Corley, 2009). The Indonesian government plans to further expand oil palm cultivation through 2020, with a projected additional area for oil palm expansion of up to 28 million hectares (Wicke et al., 2011).

Indonesia is also one of the traditional rubber latex producing countries in Southeast Asia. Indonesian rubber plantations used to be mainly "Jungle Rubber" agroforestry system (Gouyon et al., 1993), but since the 1950s, these agroforestry systems have been under pressure and have subsequently continuously been replaced by more productive monoculture rubber plantations, which generate more revenue for the local population (Feintrenie and Levang, 2009; Feintrenie et al., 2010). More recently, rubber plantations are being transformed to the above mentioned oil palm plantations, which are even more profitable, but which are strictly limited to humid tropical climates (Fox and Castella, 2013). Rubber plantations, on the other hand, have in the meanwhile also expanded to mainland Southeast Asia, e.g. Thailand, Southern China, Cambodia, and Vietnam (Ziegler et al., 2009). Nevertheless, Indonesia is still the second largest natural rubber producing country in the world, with around 3.6 million hectares of harvested area and 3.1 million tons of latex production in 2014, accounting for $25 \%$ of the global total (FAOSTAT, 2016). The Indonesian rubber plantations are mainly located on Sumatra Island (see Figure 1.2), where the conversion of tropical lowland rainforest to monoculture plantations (oil palm and rubber) is a past and on-going reality (Laumonier et al., 2010). 


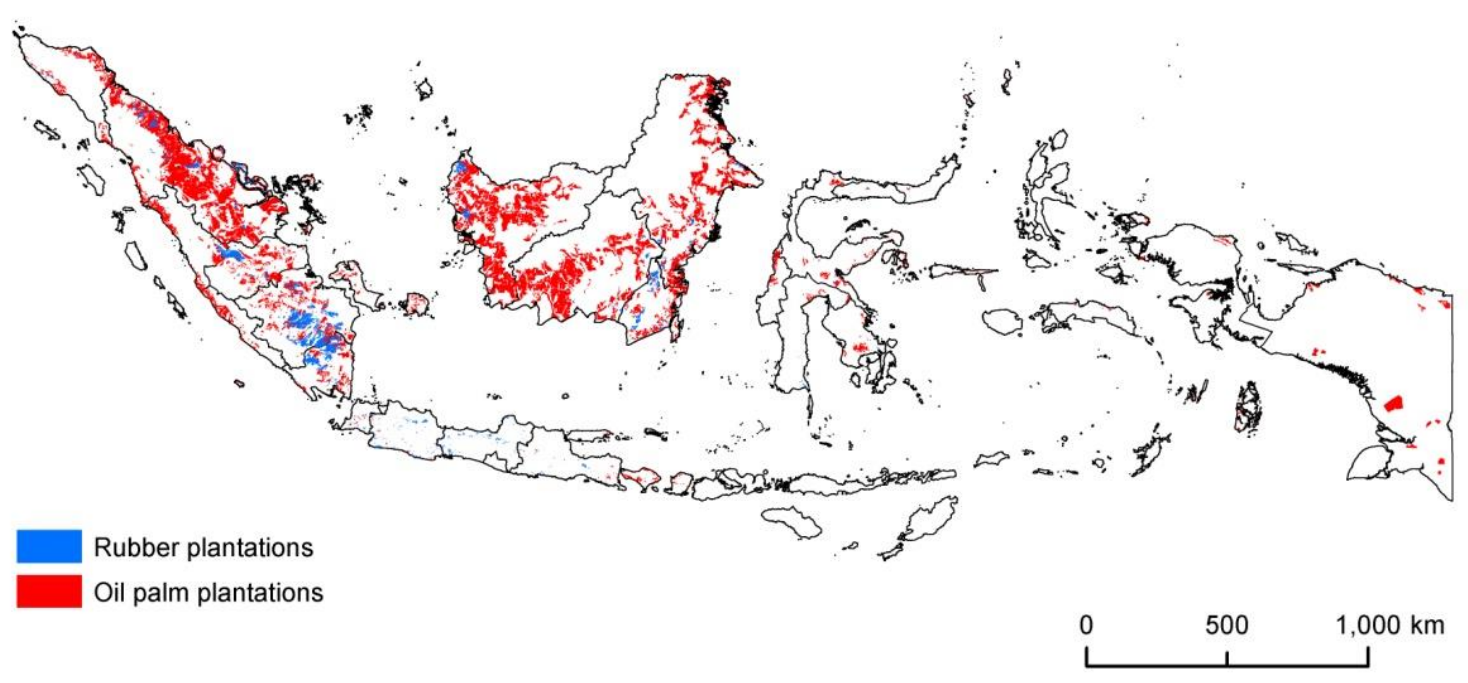

Figure 1.2 Distribution of oil palm and rubber plantations in Indonesia. Data from "Transparent World-Tree Plantations" and "Indonesia Ministry of Forestry", both accessed through "Global Forest Watch (www.globalforestwatch.org)".

\subsection{Palm and tree water use}

Many methods are used for studying tree water use, including e.g. weighing lysimeters, potometers, ventilated chambers, chemical tracing, radioisotopes tritium, stable isotopes deuterium, and sap flux measurements (see review by Wullschleger et al., 1998). Among all these methods, sap flux measurements are one of the increasingly applied methods for physiological and hydrological studies due to their relative inexpensiveness and easy applicability (Smith and Allen, 1996; Köstner et al., 1998; Lu et al., 2004). The thermal dissipation probes (TDP) developed by Granier (1985) are one of the most commonly used sap flux techniques. Their utilization is well established in many conifer and angiosperm species across temperate, subtropical and tropical regions (see reviews by Swanson, 1994; Smith and Allen, 1996; Köstner et al., 1998). Compared to other sap flux methods, TDP measurements may have a higher degree of accuracy, reliability and simplicity at relatively low costs (Lu et al., 2004), which allows for the setup and maintenance of large measurement sets for investigating water use characteristics across individuals and species and including over long periods of time to capture the temporal and spatial variability of tree water use (Do et al., 2011). The equation for calculating sap flux density based on TDP measurement is empirically derived from experiments on several tree species (Granier, 1985). After several calibration experiments conducted in a variety of studies on further species, results indicate that the original calibration equation can yield both agreement and over/underestimations in comparison to reference methods (e.g. Clearwater et al., 1999; McCulloh et al., 2007; Bush et al., 2010). It therefore seems necessary to calibrate or validate 
TDP sensors when applying them to new species (Smith and Allen, 1996; Lu et al., 2004). Several previous studies already applied the TDP method on palms and grasses, e.g. date palm (Phoenix dactylifera) (Sellami and Sifaoui, 2003; Sperling et al., 2012), coconut palm (Cocos nucifera) (Rouspard et al., 2006), Washingtonia robusta (H. Wendl.) (Renninger et al., 2009), Iriartea deltoidea and Mauritia flexuosa (Renninger and Phillips, 2010), bamboos (Dierick et al., 2010; Kume et al., 2010; Mei et al., 2015; Yang et al., 2015) and banana (Lu et al., 2002). For oil palms, on the other hand, sound data on water use characteristics are yet scarce (see reviews by Carr, 2011; Comte et al., 2012). The available data are thus far based on large-scale approaches: e.g. Radersma and Ridder (1996) estimated evapotranspiration of oil palm from the Penman-Monteith equation (3.3-6.5 $\mathrm{mm} \mathrm{d}^{-1}$ in the rainy season and $1.3-2.5 \mathrm{~mm} \mathrm{~d}^{-1}$ in the dry season), while Henson (1999) used a micrometeorological approach and reported a value around $3.8 \mathrm{~mm} \mathrm{~d}^{-1}$. Kallarackal et al. (2004) and Henson and Harun (2005) also used the micrometeorological methods reported evapotranspiration rates between $2.2-5.5 \mathrm{~mm} \mathrm{~d}^{-1}$ and $3.3-3.6 \mathrm{~mm} \mathrm{~d}^{-1}$, respectively. Insights on oil palm water use at a higher spatial resolution, on inter-palm variability and on the driving forces behind it as well as stand level transpiration rates, however, are still lacking.

In contrast to oil palm, rubber tree water use has been investigated in several studies, mainly on the Southeast Asian mainland (e.g. Guardiola-Claramonte et al., 2010; Isarangkool Na Ayutthaya et al., 2010, 2011; Tan et al., 2011; Kobayashi et al., 2014; Giambelluca et al., 2016). Using eddy covariance measurements, high evapotranspiration rates by rubber plantations have recently been reported from Southern China $\left(3.1 \mathrm{~mm} \mathrm{~d}^{-1}\right)$, Cambodia $\left(3.3 \mathrm{~mm} \mathrm{~d}^{-1}\right)$ and Northern Thailand (4.0 $\mathrm{mm} \mathrm{d}^{-1}$ ). Some of the reported rates were even higher than those of nearby natural forests, suggesting that rubber acts as a "water pump" in the local hydrological cycle (Tan et al., 2011). In contrast to these eddy covariance derived rates, applying sap flux methods, e.g. TDP measurements in a Cambodian rubber plantation or transient thermal probes in a plantation in Northeast Thailand, more moderate water use rates of rubber trees were reported: they were around $2 \mathrm{~mm} \mathrm{~d}^{-1}$ and $1.6 \mathrm{~mm} \mathrm{~d}^{-1}$, respectively (Isarangkool Na Ayutthaya et al., 2011; Kobayashi et al., 2014). This relatively large difference between eddy covariance and sap flux derived water use rates could due to differences in methodological aspects and environmental conditions (Kumagai et al., 2015). In contrast to the Asian mainland, rubber tree water use characteristics from the "maritime" environment of Indonesia have to our knowledge not yet been reported. Considering potential differences in plantation managements, site and climatic conditions, or e.g. also in the utilization of different varieties of rubber clones, rubber water use in maritime Indonesia is expected to differ from the values reported from mainland Southeast Asia. Studying rubber tree water use in "maritime" Indonesia further gives the opportunity to assess the spatial variability of rubber tree water use under different climatic conditions. 


\subsection{Objectives of the study}

This study was conducted within the framework of a big collaborative multidisciplinary project in Jambi province, Sumatra, Indonesia, called "Ecological and Socioeconomic Functions of Tropical Lowland Rainforest Transformation Systems on Sumatra, Indonesia" (EFForTS, or CRC990 project, www.uni-goettingen.de/efforts, Drescher et al., 2016). More specifically, it took place within the "A02" subproject, "Tree and palm water use characteristics in rainforest transformation systems".

The study mainly focuses on estimating water use of two mono-cultural plantation types, i.e. oil palm and rubber plantations, at both the individual and stand levels (i.e. transpiration) in maritime Indonesia. The three main objectives were:

(1) To test and if necessary adjust a widely-applied sap flux measurement technique on oil palms and rubber trees.

(2) To apply sap flux measurement in small-holder oil palm and rubber plantations in two landscapes of lowland Jambi, Indonesia, to study the magnitude of tree/palm water use at the plant and stand levels.

(3) To assess the influences of environmental drivers and plantation age on plant water use in both plantation types and to delineate similarities and differences between the two.

The study aims to refine the sap flux methods on oil palm and rubber tree and delineate differences of water use characteristics between two species. The results could contribute to shedding light on the water use characteristics of the two most important and abundant tropical cash crops under maritime climatic conditions, which could aid to further understand the local hydrological cycles of these land use systems.

This dissertation encompasses six chapters, with the first chapter being a general introduction, the second chapter giving a detailed methodological description, and chapters three to five constituting two published manuscripts and one complete draft manuscript on the water use characteristics of oil palms and rubber trees, and finally the sixth chapter synthesizing this work. 


\section{References}

Ahrends, A., Hollingsworth, P.M., Ziegler, A.D., Fox, J.M., Chen, H., Su, Y., Xu, J., 2015. Current trends of rubber plantation expansion may threaten biodiversity and livelihoods. Global Environmental Change, 34, 48-58.

Allen, K., Corre, M.D., Tjoa, A., Veldkamp, E., 2015. Soil nitrogen-cycling responses to conversion of lowland forests to oil palm and rubber plantations in Sumatra, Indonesia. PLoS ONE, 10, e0133325.

Barnes, A.D., Jochum, M., Mumme, S., Haneda, N.F., Farajallah, A., Widarto, T.H., Brose, U., 2014. Consequences of tropical land use for multitrophic biodiversity and ecosystem functioning. Nature Communications, 5, 5351.

Bush, S.E., Hultine, K.R., Sperry, J.S., Ehleringer, J.R., 2010. Calibration of thermal dissipation sap flow probes for ring-and diffuse-porous trees. Tree Physiology, 30, 1545-1554.

Carlson, K.M., Curran, L.M., Asner, G.P., Pittman, A.M., Trigg, S.N., Adeney, J.M., 2013. Carbon emissions from forest conversion by Kalimantan oil palm plantations. Nature Climate Change, 3, 283-287.

Carlson, K.M., Curran, L.M., Ratnasari, D., Pittman, A.M., Soares-Filho, B.S., Asner, G.P., Trigg, S.N., Gaveau, D.A., Lawrence, D., Rodrigues, H.O., 2012. Committed carbon emissions, deforestation, and community land conversion from oil palm plantation expansion in West Kalimantan, Indonesia. Proceedings of the National Academy of Sciences, 109, 7559-7564.

Carr, M.K.V., 2011. The water relations and irrigation requirements of oil palm (Elaeis guineensis): a review. Experimental Agriculture, 47, 629-652.

Carr, M.K.V., 2012. The water relations of rubber (Hevea brasiliensis): a review. Experimental Agriculture, 48, 176-193.

Carter, C., Finley, W., Fry, J., Jackson, D., Willis, L., 2007. Palm oil markets and future supply. European Journal of Lipid Science and Technology, 109, 307-314.

Casson, A., 2000. The hesitant boom: Indonesia's oil palm sub-sector in an era of economic crisis and political change. CIFOR Occasional paper, Bogor, Indonesia

Clearwater, M.J., Meinzer, F.C., Andrade, J.L., Goldstein, G., Holbrook, N.M., 1999. Potential errors in measurement of nonuniform sap flow using heat dissipation probes. Tree Physiology, 19, 681-687.

Comte, I., Colin, F., Whalen, J. K., Grünberger, O., Caliman, J. P., 2012. Agricultural practices in oil palm plantations and their impact on hydrological changes, nutrient fluxes and water quality in Indonesia: a review. Advances in Agronomy, 116, 71-124.

Corley, R.H.V., Tinker, P.B., 2003. Vegetative Propagation and Biotechnology, in The Oil Palm, Fourth Edition, Blackwell Science Ltd., Oxford, UK.

Corley, R.H.V., 2009. How much palm oil do we need? Environmental Science \& Policy, 12, 134-139.

Crabbe, E., Nolasco-Hipolito, C., Kobayashi, G., Sonomoto, K., Ishizaki, A., 2001. Biodiesel production from crude palm oil and evaluation of butanol extraction and fuel properties. Process biochemistry, 37, 65-71.

Curran, L.M., Trigg, S.N., McDonald, A.K., Astiani, D., Hardiono, Y.M., Siregar, P., Caniago, I., Kasischke, E., 2004. Lowland forest loss in protected areas of Indonesian Borneo. Science, 303, 1000-1003. 
de Blécourt, M., Brumme, R., Xu, J., Corre, M.D., Veldkamp, E., 2013. Soil carbon stocks decrease following conversion of secondary forests to rubber (Hevea brasiliensis) plantations. PloS ONE, 8, e69357.

DeFries, R.S., Rudel, T., Uriarte, M., Hansen, M., 2010. Deforestation driven by urban population growth and agricultural trade in the twenty-first century. Nature Geoscience, 3, 178-181.

Dierick, D., Hölscher, D., Schwendenmann, L., 2010. Water use characteristics of a bamboo species (Bambusa blumeana) in the Philippines. Agricultural and Forest Meteorology, 150, 1568-1578.

Do, F.C., Isarangkool Na Ayutthaya, S., Rocheteau, A., 2011. Transient thermal dissipation method for xylem sap flow measurement: implementation with a single probe. Tree Physiology, 31, 369-380.

Drescher, J., Rembold, K., Allen, K., Beckschäfer, P., Buchori, D., Clough, Y., Faust, H., Fauzi, A.M., Gunawan, D., Hertel, D., et al., 2016. Ecological and socio-economic functions across tropical land use systems after rainforest conversion. Philosophical Transactions of the Royal Society B: Biological Sciences, 371, 20150275.

Edem, D.O., 2002. Palm oil: biochemical, physiological, nutritional, hematological and toxicological aspects: a review. Plant Foods for Human Nutrition, 57, 319-341.

FAOSTAT, 2016. Statistics Division of Food and Agriculture Organization of the United Nations. http://faostat3.fao.org/browse/Q/QC/E. Last accessed 31 May 2016.

Feintrenie, L., Levang, P., 2009. Sumatra's rubber agroforests: advent, rise and fall of a sustainable cropping system. Small-scale Forestry, 8, 323-335.

Feintrenie, L., Chong, W.K., Levang, P., 2010. Why do farmers prefer oil palm? Lessons learnt from Bungo district, Indonesia. Small-scale Forestry, 9, 379-396.

Fitzherbert, E.B., Struebig, M.J., Morel, A., Danielsen, F., Brühl, C.A., Donald, P.F., Phalan, B., 2008. How will oil palm expansion affect biodiversity? Trends in Ecology \& Evolution, 23, 538-545.

Foster, W.A., Snaddon, J.L., Turner, E.C., Fayle, T.M., Cockerill, T.D., Ellwood, M.F., Broad, G.R., Chung, A.Y., Eggleton, P., Khen, C.V., et al., 2011. Establishing the evidence base for maintaining biodiversity and ecosystem function in the oil palm landscapes of South East Asia. Philosophical Transactions of the Royal Society B: Biological Sciences, 366, 3277-3291.

Fox, J., Castella, J.C., 2013. Expansion of rubber (Hevea brasiliensis) in Mainland Southeast Asia: what are the prospects for smallholders? The Journal of Peasant Studies, 40, 155170.

Fu, Y., Chen, J., Guo, H., Hu, H., Chen, A., Cui, J., 2010. Agrobiodiversity loss and livelihood vulnerability as a consequence of converting from subsistence farming systems to commercial plantation-dominated systems in Xishuangbanna, Yunnan, China: A household level analysis. Land Degradation \& Development, 21, 274-284.

Giambelluca, T.W., Mudd, R.G., Liu, W., Ziegler, A.D., Kobayashi, N., Kumagai, T.O., Miyazawa, Y., Lim, T.K., Huang, M., Fox, J., et al., 2016. Evapotranspiration of rubber (Hevea brasiliensis) cultivated at two plantation sites in Southeast Asia. Water Resources Research, 52, 660-679.

Gouyon, A., de Foresta, H., Levang, P., 1993. Does 'jungle rubber'deserve its name? An analysis of rubber agroforestry systems in southeast Sumatra. Agroforestry Systems, 22, 181-206.

Granier, A., 1985. Une nouvelle méthode pour la mesure du flux de sève brute dans le tronc des arbres. Annals of Forest Science, 42, 193-200.

Granier, A., 1987. Evaluation of transpiration in a Douglas-fir stand by means of sap flow measurements. Tree Physiology, 3, 309-320. 
Guardiola-Claramonte, M., Troch, P.A., Ziegler, A.D., Giambelluca, T.W., Durcik, M., Vogler, J.B., Nullet, M.A., 2010. Hydrologic effects of the expansion of rubber (Hevea brasiliensis) in a tropical catchment. Ecohydrology, 3, 306-314.

Guillaume, T., Damris, M., Kuzyakov, Y., 2015. Losses of soil carbon by converting tropical forest to plantations: erosion and decomposition estimated by $\delta 13 \mathrm{C}$. Global Change Biology, 21, 3548-3560.

Henson, I.E., Harun, M.H., 2005. The influence of climatic conditions on gas and energy exchanges above a young oil palm stand in north Kedah, Malaysia. Journal of Oil Palm Research, 17, 73-91.

Henson, I.E., 1999. Notes on oil palm productivity. IV. Carbon dioxide gradients and fluxes and evapotranspiration, above and below the canopy. Journal of Oil Palm Research, 11, 3340.

IPOC, 2006. Indonesian Palm Oil Commission, Statistik Kelapa Sawit Indonesia. Department of Agriculture, Jakarta, Indonesia.

Isarangkool Na Ayutthaya, S., Do, F.C., Pannengpetch, K., Junjittakarn, J., Maeght, J.L., Rocheteau, A., Cochard, H., 2010. Transient thermal dissipation method of xylem sap flow measurement: multi-species calibration and field evaluation. Tree Physiology, 30, 139-148.

Isarangkool Na Ayutthaya, S., Do, F.C., Pannangpetch, K., Junjittakarn, J., Maeght, J.L., Rocheteau, A., Cochard, H., 2011. Water loss regulation in mature Hevea brasiliensis: effects of intermittent drought in the rainy season and hydraulic regulation. Tree Physiology, 31, 751-762.

Kallarackal, J., Jeyakumar, P., George, S.J., 2004. Water use of irrigated oil palm at three different arid locations in Peninsular India. Journal of Oil Palm Research, 16, 45-53.

Kobayashi, N., Kumagai, T.O., Miyazawa, Y., Matsumoto, K., Tateishi, M., Lim, T.K., Mudd, R.G., Ziegler, A.D., Giambelluca, T.W., Yin, S., 2014. Transpiration characteristics of a rubber plantation in central Cambodia. Tree Physiology, 34, 285-301.

Koh, L.P., Ghazoul, J., 2008. Biofuels, biodiversity, and people: understanding the conflicts and finding opportunities. Biological Conservation, 141, 2450-2460.

Koh, L.P., Wilcove, D.S., 2008. Is oil palm agriculture really destroying tropical biodiversity? Conservation letters, 1, 60-64.

Köstner, B., Granier, A., Cermák, J., 1998. Sapflow measurements in forest stands: methods and uncertainties. Annals of Forest Science, 55, 13-27.

Kumagai, T.O., Mudd, R.G., Giambelluca, T.W., Kobayashi, N., Miyazawa, Y., Lim, T.K., Liu, W., Huang, M., Fox, J.M., Ziegler, A.D., et al., 2015. How do rubber (Hevea brasiliensis) plantations behave under seasonal water stress in northeastern Thailand and central Cambodia? Agricultural and Forest Meteorology, 213, 10-22.

Kume, T., Onozawa, Y., Komatsu, H., Tsuruta, K., Shinohara, Y., Umebayashi, T., Otsuki, K., 2010. Stand-scale transpiration estimates in a Moso bamboo forest: (I) Applicability of sap flux measurements. Forest Ecology and Management, 260, 1287-1294.

Laumonier, Y., Uryu, Y., Stüwe, M., Budiman, A., Setiabudi, B., Hadian, O., 2010. Eco-floristic sectors and deforestation threats in Sumatra: identifying new conservation area network priorities for ecosystem-based land use planning. Biodiversity and Conservation, 19, 1153-1174.

Lehébel-Péron, A., Feintrenie, L., Levang, P., 2011. Rubber agroforests' profitability, the importance of secondary products. Forests, Trees and Livelihoods, 20, 69-84.

Li, H., Aide, T.M., Ma, Y., Liu, W., Cao, M., 2007. Demand for rubber is causing the loss of high diversity rain forest in SW China. Biodiversity and Conservation, 16, 1731-1745. 
Li, H., Ma, Y., Aide, T.M., Liu, W., 2008. Past, present and future land-use in Xishuangbanna, China and the implications for carbon dynamics. Forest Ecology and Management, 255, $16-24$.

Li, Z., Fox, J.M., 2012. Mapping rubber tree growth in mainland Southeast Asia using time-series MODIS $250 \mathrm{~m}$ NDVI and statistical data. Applied Geography, 32, 420-432.

Lu, P., Urban, L., Zhao, P., 2004. Granier's thermal dissipation probe (TDP) method for measuring sap flow in trees: theory and practice. Acta Botanica Sinica, 46, 631-646.

Lu, P., Woo, K.C., Liu, Z.T., 2002. Estimation of whole plant transpiration of bananas using sap flow measurements. Journal of Experimental Botany, 53, 1771-1779.

Margono, B.A., Potapov, P.V., Turubanova, S., Stolle, F., Hansen, M.C., 2014. Primary forest cover loss in Indonesia over 2000-2012. Nature Climate Change, 4, 730-735.

McCulloh, K.A., Winter, K., Meinzer, F.C., Garcia, M., Aranda, J., Lachenbruch, B., 2007. A comparison of daily water use estimates derived from constant-heat sap-flow probe values and gravimetric measurements in pot-grown saplings. Tree Physiology, 27, 1355-1360.

Mei, T., Fang, D., Röll, A., Niu, F., Hendrayanto, Hölscher, D., 2015. Water use patterns of four tropical bamboo species assessed with sap flux measurements. Frontiers in Plant Science, 6, 1202.

Merten, J., Röll, A., Guillaume, T., Meijide, A., Tarigan, S., Agusta, H., Dislich, C., Dittrich, C., Faust, H., Gunawan, D., et al., 2016. Water scarcity and oil palm expansion: social views and environmental processes. Ecology and Society, 21, 5

Priyadarshan, P.M., Hoa, T.T.T., Huasun, H., De Gonçalves, P., 2005. Yielding potential of rubber (Hevea brasiliensis) in sub-optimal environments. Journal of Crop Improvement, $14,221-247$.

Qiu, J., 2009. Where the rubber meets the garden. Nature, 457, 246-247.

Radersma, S., de Ridder, N., 1996. Computed evapotranspiration of annual and perennial crops at different temporal and spatial scales using published parameter values. Agricultural Water Management, 31, 17-34.

Ramdani, F., Hino, M., 2013. Land use changes and GHG emissions from tropical forest conversion by oil palm plantations in Riau Province, Indonesia. PLoS ONE, 8, e70323.

Renninger, H.J., Phillips, N., 2010. Intrinsic and extrinsic hydraulic factors in varying sizes of two Amazonian palm species (Iriartea deltoidea and Mauritia flexuosa) differing in development and growing environment. American Journal of Botany, 97, 1926-1936.

Renninger, H.J., Phillips, N., Hodel, D.R., 2009. Comparative hydraulic and anatomic properties in palm trees (Washingtonia robusta) of varying heights: implications for hydraulic limitation to increased height growth. Trees, 23, 911-921.

Roupsard, O., Bonnefond, J.M., Irvine, M., Berbigier, P., Nouvellon, Y., Dauzat, J., Taga, S., Hamel, O., Jourdan, C., Saint-André, L., et al., 2006. Partitioning energy and evapotranspiration above and below a tropical palm canopy. Agricultural and Forest Meteorology, 139, 252-268.

Sellami, M.H., Sifaoui, M.S., 2003. Estimating transpiration in an intercropping system: measuring sap flow inside the oasis. Agricultural Water Management, 59, 191-204.

Sheil, D., Casson, A., Meijaard, E., Van Noordwjik, M., Gaskell, J., Sunderland-Groves, J., Wertz, K., Kanninen, M., 2009. The impacts and opportunities of oil palm in Southeast Asia. What do we know and what do we need to know? Occasional paper no. 51. CIFOR, Bogor, Indonesia.

Smith, D.M., Allen, S.J., 1996. Measurement of sap flow in plant stems. Journal of Experimental Botany, 47, 1833-1844. 
Sperling, O., Shapira, O., Cohen, S., Tripler, E., Schwartz, A., Lazarovitch, N., 2012. Estimating sap flux densities in date palm trees using the heat dissipation method and weighing lysimeters. Tree Physiology, 32, 1171-1178.

Swanson, R.H., 1994. Significant historical developments in thermal methods for measuring sap flow in trees. Agricultural and Forest Meteorology, 72, 113-132.

Tan, Z.H., Zhang, Y.P., Song, Q.H., Liu, W.J., Deng, X.B., Tang, J.W., Deng, Y., Zhou, W.J., Yang, L.Y., Yu, G.R., et al., 2011. Rubber plantations act as water pumps in tropical China. Geophysical Research Letters, 38, L24406.

USDA, 2007. United States Department of Agriculture. Indonesia: palm oil production prospects continue to grow. Available at: http://www.pecad.fas.usda.gov/highlights/2007/12/Indonesia_palmoil/. Last accessed 31 May 2016.

USDA, 2009. United States Department of Agriculture. Indonesia: palm oil production prospects continue to grow. Available at: http://www.pecad.fas.usda.gov/highlights/2009/03/indonesia/. Last accessed 31 May 2016.

Van Straaten, O., Corre, M.D., Wolf, K., Tchienkoua, M., Cuellar, E., Matthews, R.B., Veldkamp, E., 2015. Conversion of lowland tropical forests to tree cash crop plantations loses up to one-half of stored soil organic carbon. Proceedings of the National Academy of Sciences, 112, 9956-9960.

Warren-Thomas, E., Dolman, P.M., Edwards, D.P., 2015. Increasing demand for natural rubber necessitates a robust sustainability initiative to mitigate impacts on tropical biodiversity. Conservation Letters, 8, 230-241.

Wicke, B., Sikkema, R., Dornburg, V., Faaij, A., 2011. Exploring land use changes and the role of palm oil production in Indonesia and Malaysia. Land Use Policy, 28, 193-206.

Wilcove, D.S., Koh, L.P., 2010. Addressing the threats to biodiversity from oil-palm agriculture. Biodiversity and Conservation, 19, 999-1007.

Wullschleger, S.D., Meinzer, F.C., Vertessy, R.A., 1998. A review of whole-plant water use studies in tree. Tree Physiology, 18, 499-512.

Yang, S.J., Zhang, Y.J., Goldstein, G., Sun, M., Ma, R.Y., Cao, K.F., 2015. Determinants of water circulation in a woody bamboo species: afternoon use and night-time recharge of culm water storage. Tree Physiology, 35, 964-974.

Ziegler, A.D., Fox, J.M., Xu, J., 2009. The rubber juggernaut. Science, 324, 1024-1025. 
CHAPTER 2

METHODOLOGY 


\subsection{Study sites and "EFForTS design"}

The study was conducted within the framework of the above-mentioned "A02" subproject of the "EFForTS" project in the lowlands of Jambi, Sumatra, Indonesia (Figure 2.1). The Jambi province is located in the center of Sumatra Island and covers around 50 million hectares encompassing diverse land use types. Over the last decades, the natural lowland rainforests of the Jambi province have been largely transformed to rubber and oil palm monocultures; the province suffered a loss of primary forests of over 40\% from 1990 to 2010 (Margono et al., 2012).The climate in the region is tropical humid, with an average annual temperature of $26.7 \pm 0.2{ }^{\circ} \mathrm{C}$ and an annual precipitation of $2235 \pm 385 \mathrm{~mm}$, with a rainy season usually occurring between March and December and a dry season (less than $120 \mathrm{~mm}$ monthly precipitation) between June and September (data from Airport Sultan Thaha in Jambi, from 1991 to 2011, Drescher et al., 2016).

The "EFForTS" projected established 32 core study plots in four different land use types, i.e. lowland rainforest, jungle rubber, rubber and oil palm monocultures. They were spread over two lowland landscapes in Jambi province; the so called "Bukit Duabelas" and "Harapan" regions (see Figure 2.1). For each land use type, four replicate plots per landscape were established. Each of the core plots measured $50 \times 50$ meters and was equipped with a meteorological station ("Z02" subproject) to measure environmental variables. Stand structural characteristics of each plot were recorded by the "B04" subproject (Kotowska et al., 2015). Of the four mentioned land use types, this research only focused on studying the rubber and oil palm monocultures, which represent 16 (i.e. $2 \times 8$ ) out of the 32 core plots. The studied rubber and oil palm plots were all typical local small-holder monoculture plantations which ranged from 9 to 17 years old in oil palm plots and from 8 to 17 years old in rubber plots. All plots have similar Acrisol soils and have a similar elevation and other topographic traits. However, there were some differences between the two landscapes with regard to soil characteristics, i.e. soils in the Harapan region were characterized as loam Acrisols while soils in the Bukit Duabelas region were characterized as clay Acrisols (Allen et al., 2015; Guillaume et al., 2015). Further, more detailed information on the study design of the "EFForTS" project can be found in Drescher et al. (2016).

\subsection{Age class plots}

Aiming to study age effects on oil palm and rubber tree water use, besides the oil palm and rubber core plots established by the "EFForTS" project, we additionally established seven oil palm plots and two rubber plots to also cover very young and old plantations (see Figure 2.1). Of the seven additional oil palm plots, five plots were similar small-holder plantations, while two plots were located in large commercial oil palm companies. Including the core plots, a total of 15 oil palm plots ranging from 2 to 25 years old were thus studied. The mean elevation of the plots was $60 \pm$ 
$15 \mathrm{~m}$ a.s.l. (mean $\pm \mathrm{SD}$ ), average stand density was $143 \pm 22$ palms/ha. The management of the plantations included fertilization, manual and chemical weeding of ground vegetation and clearing of trunk epiphytes. It varied among the studied plantations, particularly in the two large oil palm companies. The two additional rubber plots were located directly next to one of the core plots. In the study period, they were 2 and 5 years old. In total, 10 rubber plots ranging from 2 to 17 years old were studied. The mean elevation of these plots was $78 \pm 15 \mathrm{~m}$ a.s.l., mean stand density was $502 \pm 147$ trees/ha, with a mean tree diameter of $13.6 \pm 2.9 \mathrm{~cm}$ and a mean tree height of $10.9 \pm$ $1.6 \mathrm{~m}$. All rubber plots were typical local small-holder plantations under similar management, including the regular harvest of rubber latex and occasional fertilizer application (Kotowska et al., 2015).

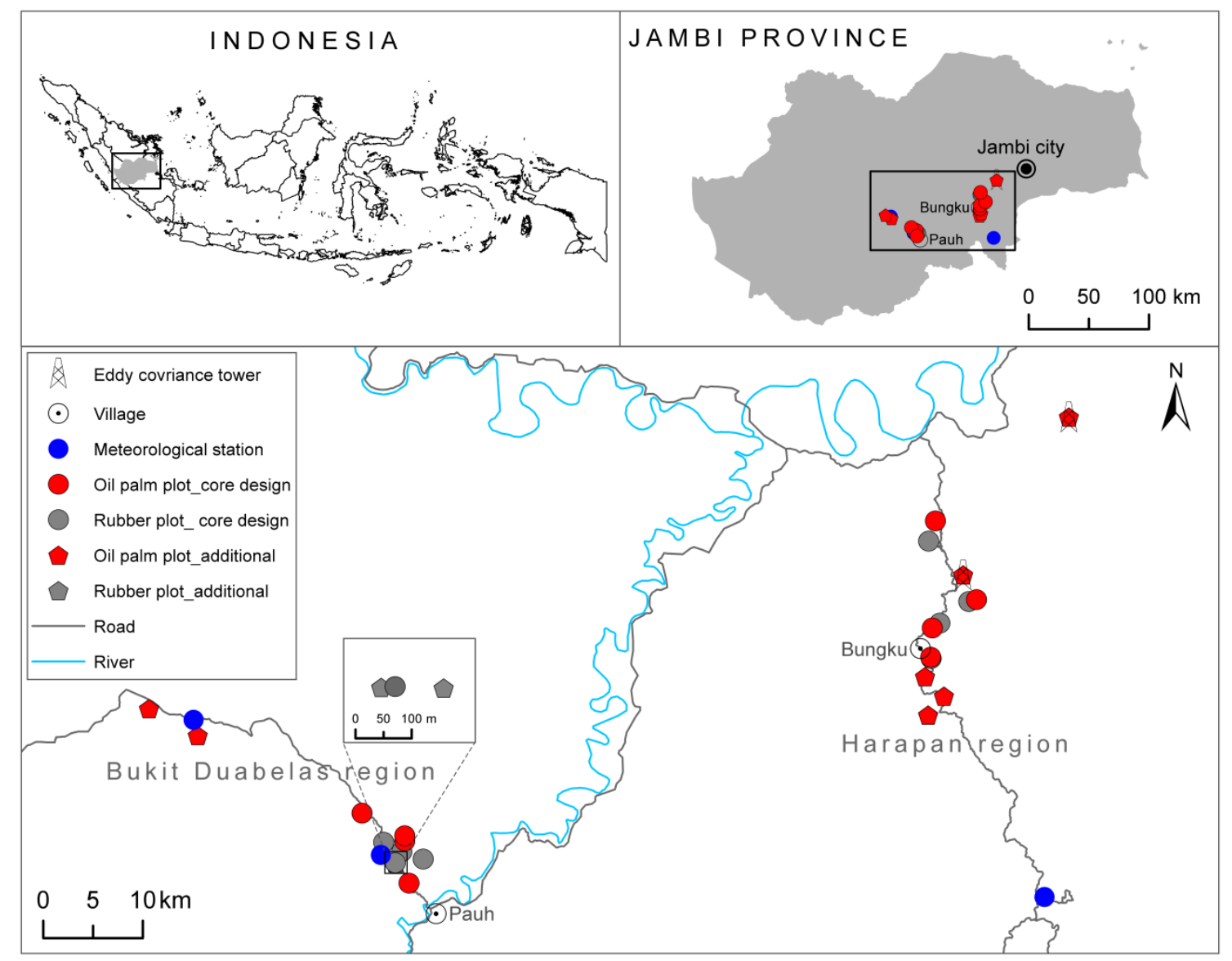

Figure 2.1 Locations of the studied plots in Jambi province, Sumatra, Indonesia. 


\subsection{Sap flux measurements on oil palms}

Thermal dissipation probes (TDP) originally developed by Granier $(1985,1987)$ were used for sap flux measurements. The TDP sensors were installed on palm leaf petioles rather than in the trunk due to abundant butts of pruned leaf petioles remaining on the trunk and hindering easy access. Additionally, we hypothesized that vessel density could be higher and their distribution more homogeneously in the leaf petioles than in the trunk. Previous studies (e.g. Lu et al., 2004; Bush et al., 2010) suggested that the calibration or validation is necessary when the TDP method is applied to new species. We thus firstly conducted species-specific laboratory calibration of TDP sensors on oil palm leaf petioles following the approach by Steppe et al. (2010). Additionally, dying experiments were conducted to determine the extension of the water conductive area in oil palm leaf petioles.

In the field, we had one oil palm long-term monitoring plot (ca. one year), in which ten oil palms were studied; on four out of ten palms, leaves in North, East, South and West were selected for TDP measurements, and two leaves with higher and lower inclinations were chosen in each direction. On the remaining six palms, only two directions (i.e. North and South) were selected (see Figure 2.2 for the field installation). After sensor installation, insulative materials and aluminum foil were used to shield the sensor in order to minimize natural temperature gradients and reflect radiation, and durable plastic foil was added for protection from rain. The sensors were connected to a multiplexer (AM16/32, Campbell Scientific Inc., Logan, USA), which was wired to a data logger (CR1000, Campbell Scientific Inc.). Data were recorded in 30-second intervals and stored as 10-minute averages.

In the remaining 14 of the 15 studied oil palm plots, we only conducted sap flux measurements for periods of four to five weeks due to the practical constraints. In these plots, four palms each were chosen for sap flux measurements. There, on each palm, four leaves in two directions (North and South) with two inclinations (higher and lower) were selected for measurement. Apart from that, the setup was identical to that in the long-term monitoring plot. The uncertainty of sap flux estimates with this sampling scheme due to limited sample size was analyzed in detail (see Chapter 3).

Further details on TDP sensor specification, the laboratory calibration experiment, the exact field setup and the process of scaling up to palm and stand water use are provided in Chapter 3. 

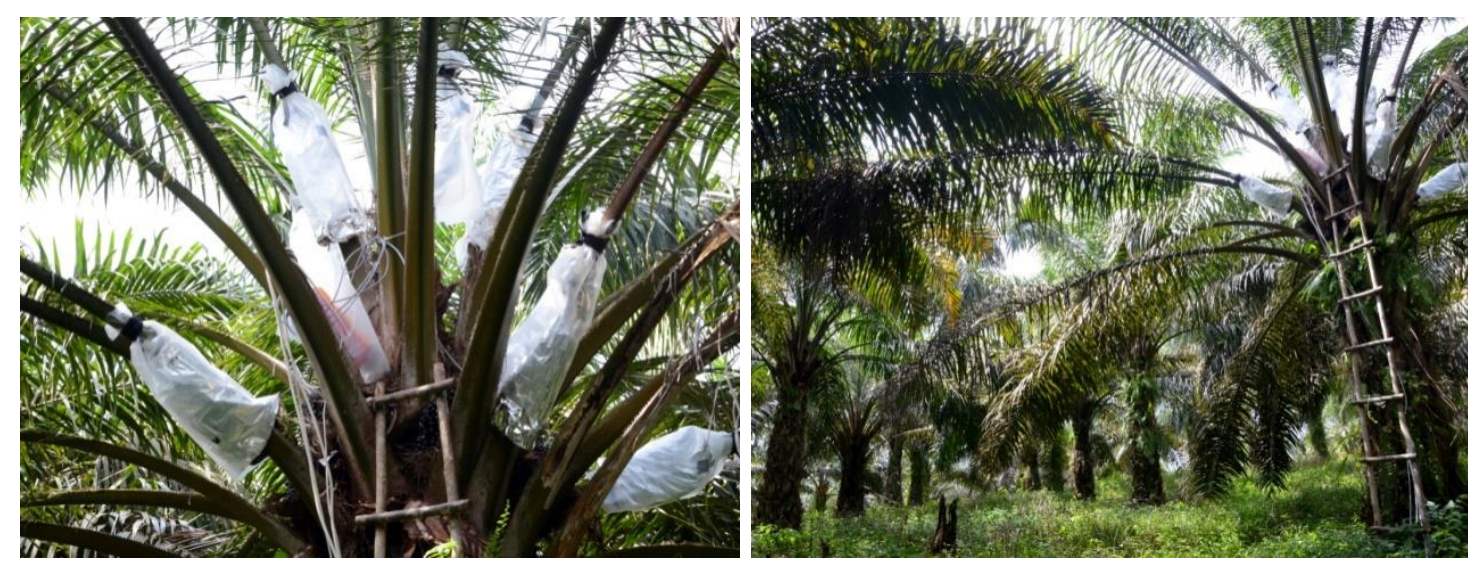

Figure 2.2 Field installation of TDP sensors on oil palms in the long-term monitoring plot.

\subsection{Sap flux measurements on rubber trees}

We used same approach as for oil palm to calibrate/validate the TDP sensors on rubber trees in laboratory calibration experiments. Then, in a long-term monitoring rubber plot, three different sap flux techniques were combined to test the reliability of TDP sap flux measurement on rubber trees under field conditions. The heat field deformation (HFD, Nadezhdina et al., 1998) technique was applied to assess changes of sap flux density along the radial axis (i.e. radial profile of sap flux density). This subsequently served to scale up from TDP point measurement to whole tree water use (Čermák et al., 2004; Nadezhdina et al., 2012). Then, water use rates derived from TDP and HFD measurements were compared with rates derived from the stem heat balance (SHB, Sakuratani, 1981) method. The latter was reported to yield relatively accurate estimations of water use without further calibration if underlying thermal assumptions are fulfilled (Baker and Van Bavel, 1987; Perämäki et al., 2001).

Ten rubber trees were chosen for conducting TDP measurements in a long-term monitoring plot (see Figure 2.3 for the field installation). The TDP sensors were installed in the trunk, at a height of ca. $2.6 \mathrm{~m}$, above the tapping area. Two sensors were installed on each tree, in North and South of the trunk, respectively. In analogy to the installation on oil palms, sensors were covered by insulative materials and aluminum foil in order to minimize natural temperature gradients and reflect radiation after installation; durable plastic foil was added for protection from rain. Multiplexers and data loggers (AM16/32 and CR1000) were used to record data in 30-second intervals, which were stored as 10-minute averages. In nine further rubber plots, the sampling setup was identical to that in the long-term monitoring plot, except for measuring on a reduced number of trees (i.e. six trees per plot instead of 10).

More details on sensor installation of the three applied sap flux techniques as well as on field setup and plot characteristics are provided in chapter 5 . 


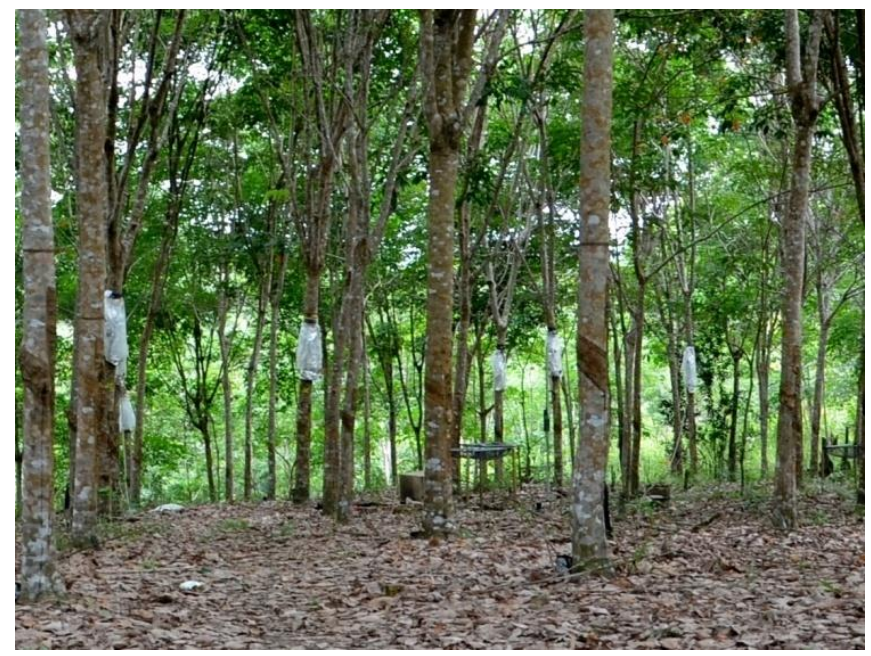

Figure 2.3 Field installations of TDP measurements on rubber trees in the long-term monitoring rubber plot.

\subsection{Meteorological measurements}

Meteorological measurements were conducted by the "A03 and Z02" subprojects. Several meteorological stations were set up in open areas at varying distances to the study plots (see Figure 2.1). Air temperature and air relative humidity were measured with a Thermohygrometer (type 1.1025.55.000, Thies Clima, Göttingen, Germany) to derive vapor pressure deficit (VPD). Global radiation was measured with a radiation sensor (CMP3 Pyranometer, Kipp \& Zonen, Delft, The Netherlands). All meteorological data were recorded in 15-second intervals and stored as 1-minute averages by data loggers (LogTrans16-GPRS, UIT, Dresden, Germany). Furthermore, smaller micrometeorological stations were placed in each of the core plots to measure several environmental variables: thermohygrometers (Galltec Mela ${ }^{\circledR}$ ) were placed at a height of 2 meters to record air temperature $\left({ }^{\circ} \mathrm{C}\right)$ and relative humidity $(\%)$ under the canopy, and soil sensors (Trime-Pico 32, IMKO, Ettlingen, Germany) were installed in the center of each core plot at a depth of 0.3 meters into the soil to record soil temperature and soil moisture. Data were recorded as hourly averages by data loggers (LogTrans16-GPRS).

\subsection{Eddy covariance measurements}

Eddy covariance measurements were conducted by the above-mentioned "A03" subproject in two oil palm plots (see Figure 2.1), in which we simultaneously ran sap flux measurements (see Figure 2.4). This allowed to estimate the contribution of transpiration to total evapotranspiration. The eddy towers were 7 and 22 meters in height and were equipped with a sonic anemometer (Metek uSonic-3 Scientific, Elmshorn, Germany) to measure the three components of the wind vector and an open path carbon dioxide and water analyzer (Li-7500A, Licor Inc., Lincoln, USA) to derive evapotranspiration rates (Meijide et al., in review). Fluxes were calculated with the 
software EddyPro (Licor Inc.), planar-fit coordinate rotated, corrected for air density fluctuation and quality controlled. A more detailed description of the eddy covariance methodology can be found in chapter 4 , which presents results of sap flux and eddy covariance measurements in a young and a mature oil palm plantation.
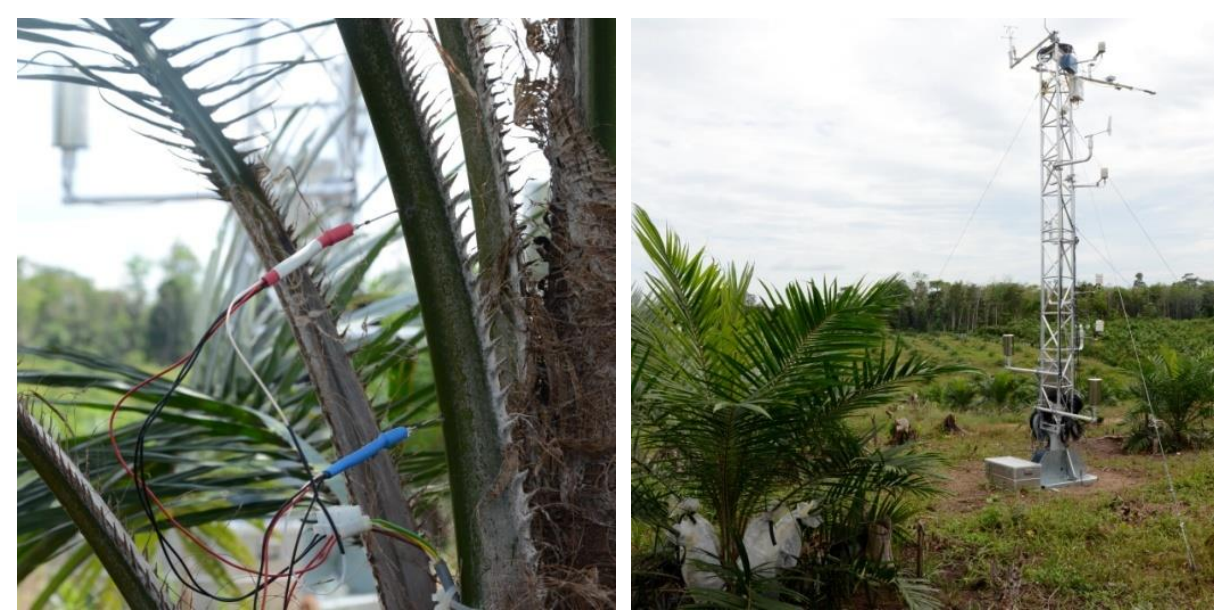

Figure 2.4 Parallel sap flux and eddy covariance measurements in a young oil palm plantation.

\section{References}

Allen, K., Corre, M.D., Tjoa, A., Veldkamp, E., 2015. Soil nitrogen-cycling responses to conversion of lowland forests to oil palm and rubber plantations in Sumatra, Indonesia. PLoS ONE, 10, e0133325.

Baker, J.M., Van Bavel, C.H.M, 1987. Measurement of mass flow of water in the stems of herbaceous plants. Plant, Cell \& Environment, 10, 777-782.

Bush, S.E., Hultine, K.R., Sperry, J.S., Ehleringer, J.R., 2010. Calibration of thermal dissipation sap flow probes for ring-and diffuse-porous trees. Tree Physiology, 30, 1545-1554.

Čermák, J., Kučera, J., Nadezhdina, N., 2004. Sap flow measurements with some thermodynamic methods, flow integration within trees and scaling up from sample trees to entire forest stands. Trees, 18, 529-546.

Drescher, J., Rembold, K., Allen, K., Beckschäfer, P., Buchori, D., Clough, Y., Faust, H., Fauzi, A.M., Gunawan, D., Hertel, D., et al., 2016. Ecological and socio-economic functions across tropical land use systems after rainforest conversion. Philosophical Transactions of the Royal Society B: Biological Sciences, 371, 20150275.

Granier, A., 1985. Une nouvelle méthode pour la mesure du flux de sève brute dans le tronc des arbres. Annals of Forest Science, 42, 193-200.

Granier, A., 1987. Evaluation of transpiration in a Douglas-fir stand by means of sap flow measurements. Tree Physiology, 3, 309-320.

Guillaume, T., Damris, M., Kuzyakov, Y., 2015. Losses of soil carbon by converting tropical forest to plantations: erosion and decomposition estimated by $\delta 13 \mathrm{C}$. Global Change Biology, 21, 3548-3560. 
Kotowska, M.M., Leuschner, C., Triadiati, T., Meriem, S., Hertel, D., 2015. Quantifying above and belowground biomass carbon loss with forest conversion in tropical lowlands of Sumatra (Indonesia). Global Change Biology, 21, 3620-3634.

Lu, P., Urban, L., Zhao, P., 2004. Granier's thermal dissipation probe (TDP) method for measuring sap flow in trees: theory and practice. Acta Botanica Sinica, 46, 631-646.

Margono, B.A., Turubanova, S., Zhuravleva, I., Potapov, P., Tyukavina, A., Baccini, A., Goetz, S., Hansen, M.C., 2012. Mapping and monitoring deforestation and forest degradation in Sumatra (Indonesia) using Landsat time series data sets from 1990 to 2010. Environmental Research Letters, 7, 034010.

Meijide, A., Röll, A., Fan, Y., Herbst, M., Niu, F., Tiedemann, F., June, T., Rauf, A., Hölscher, D., Knohl, A., Controls of water and energy fluxes in oil palm plantations: effect of environmental variables and oil palm age. In review.

Nadezhdina, N., Cermák, J., Nadezhdin, V., 1998. Heat field deformation method for sap flow measurements. In: Cermák, J., Nadezhdina, N. (Eds.), Proceedings of the 4th International Workshop on Measuring Sap Flow in Intact Plants. Publishing House of Mendel University, Czech Republic, 72-92.

Nadezhdina, N., Vandegehuchte, M.W., Steppe, K., 2012. Sap flux density measurements based on the heat field deformation method. Trees, 26, 1439-1448.

Perämäki, M., Nikinmaa, E., Sevanto, S., Ilvesniemi, H., Siivola, E., Hari, P., Vesala, T., 2001. Tree stem diameter variations and transpiration in Scots pine: an analysis using a dynamic sap flow model. Tree Physiology, 21, 889-897.

Sakuratani, T., 1981. A heat balance method for measuring water flux in the stem of intact plants. Journal of Agricultural Meteorology, 37, 9-17.

Steppe, K., De Pauw, D.J., Doody, T.M., Teskey, R.O., 2010. A comparison of sap flux density using thermal dissipation, heat pulse velocity and heat field deformation methods. Agricultural and Forest Meteorology, 150, 1046-1056. 


\title{
CHAPTER 3
}

\section{OIL PALM WATER USE: CALIBRATION OF A SAP FLUX METHOD AND A FIELD MEASUREMENT SCHEME}

\author{
Furong Niu ${ }^{1^{*} \dagger}$, Alexander Röll ${ }^{1^{*}}$, Afik Hardanto ${ }^{1,2}$, Ana Meijide ${ }^{3}$, Michael Köhler ${ }^{1}$, \\ Hendrayanto ${ }^{4}$, Dirk Hölscher ${ }^{1}$
}

* The authors contributed equally to this work.

${ }^{1}$ Tropical Silviculture and Forest Ecology, Georg-August-Universität Göttingen, Germany

${ }^{2}$ Universitas Jenderal Soedirman, Indonesia

${ }^{3}$ Bioclimatology, Georg-August-Universität Göttingen, Germany

${ }^{4}$ Department of Forest Management, Institut Pertanian Bogor, Indonesia

${ }^{\dagger}$ Correspondence to: Furong Niu, Tropical Silviculture and Forest Ecology, Georg-AugustUniversität Göttingen, Büsgenweg 1, 37077 Göttingen, Germany. E-mail: $\underline{\text { fniu@gwdg.de }}$

Published in Tree Physiology (2015) 35: 563-573, doi: 10.1093/treephys/tpv013 


\begin{abstract}
Oil palm (Elaeis guineensis Jacq.) water use was assessed by sap flux density measurements with the aim to establish the method and derive water use characteristics. Thermal dissipation probes were inserted into leaf petioles of mature oil palms. In the laboratory, we tested our set-up against gravimetric measurements and derived new parameters for the original calibration equation which are specific to oil palm petioles. In the lowlands of Jambi, Indonesia, in a 12-year-old monoculture plantation, 56 leaves on 10 palms were equipped with one sensor per leaf. A 10-fold variation in individual leaf water use among leaves was observed, but we did not find significant correlations to the variables trunk height and diameter, leaf azimuthal orientation, leaf inclination or estimated horizontal leaf shading. We thus took an un-stratified approach to determine an appropriate sampling design to estimate stand transpiration $\left(E_{\mathrm{s}}, \mathrm{mm} \mathrm{d}^{-1}\right)$ rates of oil palm. We used the relative standard error of the mean $\left(\mathrm{SE}_{\mathrm{n}}, \%\right)$ as a measure for the potential estimation error of $E_{\mathrm{s}}$ associated with sample size. It was $14 \%$ for a sample size of 13 leaves to determine the average leaf water use and four palms to determine the average number of leaves per palm. Increasing these sample sizes only led to minor further decreases of the $\mathrm{SE}_{\mathrm{n}}$ of $E_{\mathrm{s}}$. The observed 90-day average of $E_{\mathrm{s}}$ was $1.1 \mathrm{~mm} \mathrm{~d}^{-1}$ (error margin $\pm 0.2 \mathrm{~mm} \mathrm{~d}^{-1}$ ), which seems relatively low, but does not contradict Penman-Monteith-derived estimates of evapotranspiration. Examining the environmental drivers of $E_{\mathrm{s}}$ on an intra-daily scale indicates an early, pre-noon maximum of $E_{\mathrm{s}}$ rates $(11 \mathrm{am})$ due to a very sensitive reaction of $E_{\mathrm{s}}$ to increasing vapor pressure deficit in the morning. This early peak is followed by a steady decline of $E_{\mathrm{s}}$ rates for the rest of the day, despite further rising levels of vapor pressure deficit and radiation; this results in pronounced hysteresis, particularly between $E_{\mathrm{s}}$ and vapor pressure deficit.
\end{abstract}

Keywords: sample size, thermal dissipation probes, transpiration, error margins, environmental drivers 


\subsection{Introduction}

Oil palms (Elaeis guineensis Jacq.) are cultivated in large areas of humid tropical lowlands and a further expansion is predicted (FAO, 2014). Information on oil palm water use characteristics is limited and the available studies are based on micrometeorological, soil water budget or catchment approaches (e.g. Radersma and de Ridder, 1996; Kallarackal et al., 2004). Sap flux techniques may contribute to generating further information, e.g. on a smaller spatial scale, but to our knowledge have not yet been applied to oil palms.

A widely used sap flux technique is the thermal dissipation probe (TDP) method (Granier, 1985, 1987). It has been applied to study water use characteristics of dicot trees (e.g. Wilson et al., 2001; Kunert et al., 2012) and relatively recently also of monocot species such as bamboos (Dierick et al., 2010; Kume et al., 2010a) or palms (e.g. Renninger et al., 2010; Sperling et al., 2012). If the TDP method is calibrated, it can give reliable results (Bush et al., 2010; Sun et al., 2012), is less costly than other methods and can therefore be used at a relatively high number of spatial replicates within or between stands.

For palms, insights on hydrological characteristics remain scarce. Measuring sap flux density in the trunk of palms, radial variations in sap flux density have been observed in date palms (Phoenix dactylifera L.) (Sellami and Sifaoui, 2003; Sperling et al., 2012), while it was constant at all depths for coconut palms (Cocos nucifera L.) (Roupsard et al., 2006). Axial variations of sap flux density have also been observed, from the roots over different heights of the trunk to leaf petioles, revealing certain time lags in the response of sap flux density that may point towards internal water storage mechanisms (Sellami and Sifaoui, 2003; Renninger et al., 2010).

In many palms, the large dimensions of leaf petioles and their presumably higher vessel density compared to the trunk, as well as the presumed homogeneity in the distribution of vascular bundles, make petioles a suitable location for measurements with thermal methods (Madurapperuma et al., 2009; Renninger et al., 2009). Extrapolated to water use per palm, measurements on leaf petioles have proven to compare well to those from the trunk (Renninger and Phillips, 2010).

When scaling up from leaves to the transpiration of a whole stand, the sample size (i.e. the number of leaves measured) should be large enough to capture the variability that is likely to occur. In some cases, stratification, e.g. with respect to azimuth, plant size or other variables, may be advisable. Among others, Kume et al. (2010b) statistically derived potential errors in estimates of stand transpiration associated with sample sizes and suggested an "optimal" sample size after which the decrease in error with increasing sample size is marginal. 
In our study, we tested the TDP method on oil palm leaf petioles in the laboratory and applied this method to oil palms in a small-holder plantation in the lowlands of Jambi, Indonesia. The objectives were (1) to test and if necessary derive oil-palm-petiole-specific parameters for the original calibration equation by Granier (1985), (2) to derive an appropriate measurement scheme for field studies with respect to the positioning and number of sensors, (3) to estimate stand transpiration including error margins, and (4) to evaluate the transpiration response to fluctuations in vapor pressure deficit and radiation. The study may thus contribute to optimizing sap flux based field measurement schemes and to generating insight on the water use characteristics of oil palms.

\subsection{Methods}

\subsubsection{Laboratory calibration experiment}

\subsubsection{Basic considerations and technical specifications}

Sensors were installed in leaf petioles rather than in the trunk because vessel density is presumably higher and distributed more homogeneously. We used thermal dissipation probes (TDP, Granier, 1987, 1996a) of $12.5 \mathrm{~mm}$ in length and $2.0 \mathrm{~mm}$ in diameter (36 windings of heating wire) to measure sap flux density $\left(J_{\mathrm{s}}, \mathrm{g} \mathrm{cm}^{-2} \mathrm{~h}^{-1}\right)$ in oil palms. We diverged from the original probe length $(12.5$ instead of $20 \mathrm{~mm})$ to reduce the spatial variability of sap flux density and of water conducting properties along the sensor (Clearwater et al., 1999; James et al., 2002). The downstream probe of each sensor was connected to a $12 \mathrm{~V}$ power source and heated continuously by the Joule effect, following the specifications by Granier (1987, 1996a). Due to the reduced probe length, and the subsequently reduced electrical resistance, the power output per probe was lower than for the original probes; however, the probe loading, i.e. the power output per $\mathrm{cm}$ of probe, was identical (approx. $0.1 \mathrm{~W} \mathrm{~cm}^{-1}$ ). The differential voltage between heated probe and reference probe was recorded by a CR1000 data logger (Campbell Scientific Inc., Logan, UT, USA) every $30 \mathrm{sec}$ and averaged and stored every $10 \mathrm{~min}$.

\subsubsection{Experimental set-up}

The calibration experiment was conducted in the laboratory of the University of Jambi, Indonesia. Mature and healthy oil palm leaves were cut from a plantation near campus in the early morning; they were immediately submerged into clean water. In the laboratory, the petiole-segments were re-cut under water and shaved with a razor blade (Renninger et al., 2010; Steppe et al., 2010). The prepared segments were vertically suspended into a PVC pipe (Figure 3.1). Eight segments with a length of $60 \mathrm{~cm}$ were used for the calibration experiments. A siphon construction (Figure 3.1) was used to control the water level in the pipe (also see Steppe et al., 2010). To allow the reading from the TDP sensors to stabilize, each pressure regime was upheld for $30 \mathrm{~min}$ before decreasing the 
water level in steps of $20 \mathrm{~cm}$. The procedure was repeated various times to ensure a broad spectrum of sap flux densities in the recorded data. We used purified water with $20 \mathrm{mM} \mathrm{KCl}$ for the calibration experiments to decrease hydraulic resistance (Zwieniecki et al., 2001).

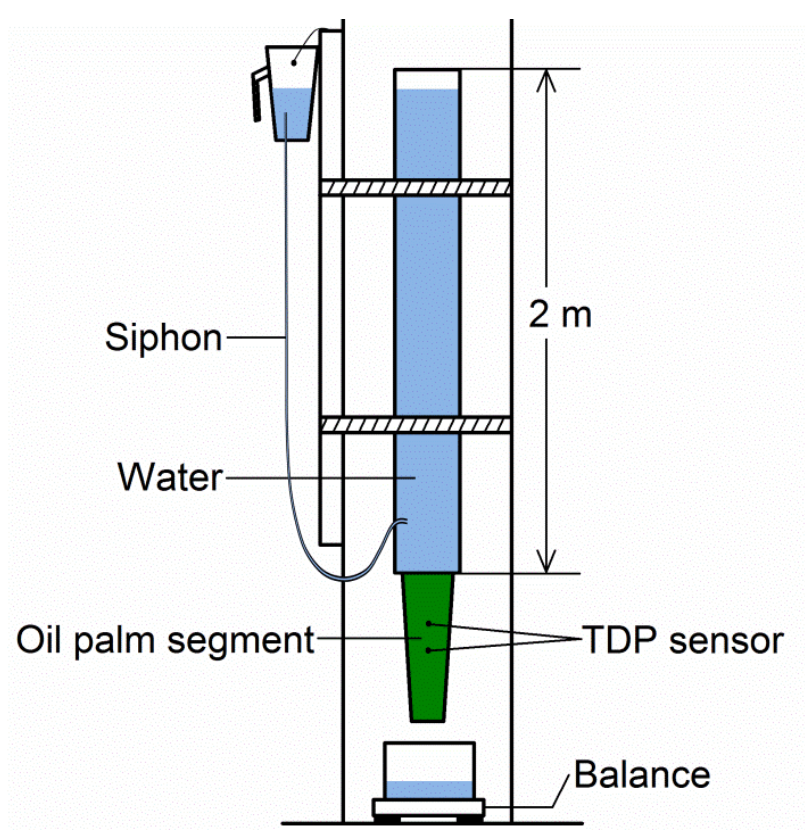

Figure 3.1 Experimental set-up for the comparison of thermal dissipation probe (TDP) measurements with gravimetric readings on oil palm petioles (calibration experiment).

The two probes of each sensor were inserted into pre-drilled holes on the underside of petiolesegments (Figure 3.2a), at a distance of $10 \mathrm{~cm}$. Prior to insertion into the leaf, probes were covered with heat conductive paste and slid into tightly fitting aluminum sleeves. To provide a reference measure for the TDP-derived sap flux density, a container was placed on a balance (0.01 $\mathrm{g}$ resolution) below the segment to record the water flow $\left(\mathrm{g} \mathrm{h}^{-1}\right)$ through the segment. Dividing the recorded flow by water conductive area $\left(A_{c}, \mathrm{~cm}^{2}\right)$ yielded the gravimetric sap flux density $\left(J_{\mathrm{g}}, \mathrm{g} \mathrm{cm}^{-2} \mathrm{~h}^{-1}\right)$.

To quantify the $A_{\mathrm{c}}$ of leaf petioles and to allow for a visual examination of the variability of vessel density $\left(D_{\mathrm{v}}, \mathrm{cm}^{-2}\right)$ over this area, seven additional segments were cut and set up in the same way as for the calibration experiment; a $0.1 \%$ indigo carmine solution was added to the purified water and the water was pressured through each segment for $4-6$ hours. After staining, each segment was sawn into cross-sectional pieces. Photos were taken and the $A_{\mathrm{c}}$ and the baseline length $\left(L_{\mathrm{b}}\right.$, $\mathrm{cm}$ ) (Figure 3.2a) of each piece were calculated with Image J (Image J, National Institutes of Health, Bethesda, MD, USA, http://imagej.nih.gov/ij/, 26 February 2015, date last accessed). A linear regression was used to examine the relationship between $L_{\mathrm{b}}$ and $A_{\mathrm{c}}$. To examine the withinsegment variability of $D_{\mathrm{v}}$, ten $1 \mathrm{~cm}^{2}$ squares were evenly distributed over the cross-sectional area 
of each segment, and the vessels that lay within each square were counted on digitally enlarged pictures.

\subsubsection{Deriving new parameters for the calibration equation}

The recorded signals from the TDP sensors were converted into sap flux density $\left(J_{\mathrm{s}}, \mathrm{g} \mathrm{cm}^{-2} \mathrm{~h}^{-1}\right)$ with the original calibration equation by Granier (1985):

$$
J_{\mathrm{s}}=a K^{b}
$$

Where $a$ and $b$ are equation parameters (Granier 1985: $a=42.84, b=1.231$ ), and $K$ is defined as:

$$
K=\frac{\Delta T_{\max }-\Delta T}{\Delta T}
$$

Where $\Delta T_{\max }\left({ }^{\circ} \mathrm{C}\right)$ is the temperature difference between heated and reference probe under zeroflux conditions, and $\Delta T\left({ }^{\circ} \mathrm{C}\right)$ is the temperature difference at a given time-step. To determine $\Delta T_{\max }$ under laboratory conditions, the segments were suspended horizontally for several hours.

For deriving oil-palm-petiole-specific parameters $a$ and $b$ for the calibration equation, we first randomly selected 10 observations from the gravimetric vs. TDP-derived sap flux density data pairs (10-minute-averages) for each segment used in the experiments. This ensured that all segments entered the calibration procedure with the same weights, since the number of observations was not equal for all segments. We then pooled the selected observations of all segments. To create a dataset for a cross validation of the newly-derived parameters, we randomly split the pooled dataset in two halves: one for deriving new parameters, and the other for the validation. In the validation dataset, we tested the performance of the new parameters $a$ and $b$ on a dataset not included in the fitting process. We compared $J_{\mathrm{s}}$ values derived from the original and the new parameters, respectively, to the reference $J_{\mathrm{g}}$ values by using the Wilcoxon signed-rank test. To ensure the stability of the result, we repeated this procedure 10,000 times.

\subsubsection{Field study}

\subsubsection{Study site}

The field study was carried out in a 12-year-old small-holder monoculture oil palm plantation $\left(2^{\circ} 04^{\prime} 15.2^{\prime \prime} \mathrm{S}, 102^{\circ} 47^{\prime} 30.6^{\prime \prime} \mathrm{E}\right)$ in Jambi, Indonesia, at an elevation of $71 \mathrm{~m}$ above sea level (a.s.1.) on a southward-facing slope with an inclination of about $20^{\circ}$. The site is part of a larger experimental set-up of the CRC990 (www.uni-goettingen.de/crc990, 26 February 2015, date last accessed) and is referred to as "BO3". At the Jambi airport, approximately $100 \mathrm{~km}$ distant from our plot, the average annual temperature was $26.7 \pm 1.0^{\circ} \mathrm{C}$ (data from 1991 to 2011 ; mean $\pm \mathrm{SD}$ ), 
with little intra-annual variation. Annual precipitation was $2235 \pm 385 \mathrm{~mm}$; a dry season with less than $120 \mathrm{~mm}$ monthly precipitation usually occurred between June and September, but the magnitude of dry season rainfall patterns varied highly between years (A. Meijide et al. unpublished data). Soil type in the plot is a clay acrisol (K. Allen et al., S. Kurniawan et al. unpublished data). The palms are $4.2 \pm 0.6 \mathrm{~m}$ (mean $\pm \mathrm{SD}$ ) high, with a diameter at breast height (DBH, cm) of $81 \pm 7 \mathrm{~cm}$ and $40 \pm 2$ leaves per palm. The stand density is $138 \mathrm{ha}^{-1}$. Management activities included regular fruit harvest and pruning of lower leaves; fertilizer and pesticides were regularly applied on the plot in quantities typical for small-holder plantations in the region (M. M. Kotowska et al. unpublished data).

\subsubsection{Environmental measurements}

A micrometeorological station was set up approx. $3 \mathrm{~km}$ from the BO3 plot. It was placed in open terrain. Air temperature and relative humidity were measured at a height of $2 \mathrm{~m}$ with a Thermohygrometer (type 1.1025.55.000, Thies Clima, Göttingen, Germany) to calculate vapor pressure deficit (VPD, $\mathrm{kPa}$ ). Wind speed was measured with a three cup anemometer (Thies Clima) at a height of $4 \mathrm{~m}$. A net radiation sensor (NR Lite2, spectral range 200-100,000 nm, Kipp \& Zonnen, Delft, The Netherlands) and a short wave radiation sensor (CMP3 Pyranometer, spectral range 300-2800 nm, Kipp \& Zonen) were installed at a height of $3 \mathrm{~m}$, the latter to

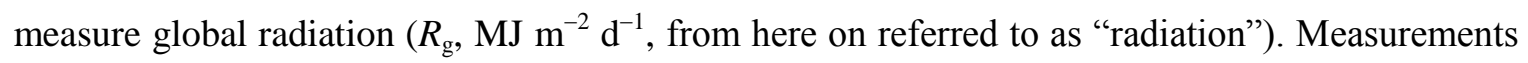
were taken every $15 \mathrm{sec}$ and averaged and stored on a DL16 Pro data logger (Thies Clima) every $10 \mathrm{~min}$. A soil moisture sensor (Trime-Pico 32, IMKO, Ettlingen, Germany) was placed in the center of the research plot at a depth of $0.3 \mathrm{~m}$ into the soil and was connected to a data logger (LogTrans16-GPRS, UIT, Dresden, Germany). Data were recorded hourly. During our observation period soil moisture never fell below 35 vol. \%. All data were recorded for our full 90-day sap flux measurement period (from 3 July to 30 September 2013).

Evapotranspiration ( $\mathrm{mm} \mathrm{d}^{-1}$ ) was calculated with the FAO Penman-Monteith-equation (FAO 56: Allen et al., 1998) based on the previously described micrometeorological input variables and using a crop coefficient of 0.9 for mature oil palm plantations (Carr, 2011).

\subsubsection{Sap flux measurements}

We installed sap flux sensors in 56 oil palm leaf petioles, with one sensor per leaf. 10 palms with a trunk height between 3.2 and $5.3 \mathrm{~m}$ were selected. On four palms, we equipped eight leaves in the North, East, South and West with sensors; on the remaining palms, four leaves were equipped (North and South only). In each direction, we installed sensors on one leaf of higher $\left(65-85^{\circ}\right)$ and one leaf of lower $\left(45-65^{\circ}\right)$ inclination (Figure 3.2b). The sensors were placed approx. $0.5 \mathrm{~m}$ from the base of the petiole at the trunk, approx. $0.4 \mathrm{~m}$ (upstream) from the first leaflets. Probe 
preparation and installation, technical specifications and data logging were identical to the calibration experiments (see 3.2.1); sensors were protected from environmental influences with various layers of insulative materials. The 90-day measurement period lasted from 3 July to 30 September 2013.

The water conductive area of each sample leaf in the field was estimated from the baseline length between upper and lower probe (Figure 3.2a) by using the regression derived from staining experiments (see 3.2.1.2). Sap flux densities were calculated with the calibration equation by Granier (1985), but with newly-derived parameters (see 3.2.1.3). To assure that zero-flux nighttime conditions were met under field conditions, we examined the values in our sap flux dataset adjacent to the respective values of $\Delta T_{\max }$ (following Oishi et al., 2008); they remained stable over several hours during the early morning hours, when VPD was consistently below 0.1 $\mathrm{kPa}$; we thus think that zero-flux nighttime conditions were met during our measurement period.

\subsubsection{Leaf and palm characteristics}

For all sample leaves, orientation and inclination at the base of the petiole were recorded. The horizontally projected relative area of each leaf that was covered by overlying leaves at a zenith angle of zero ("horizontal leaf shading") was roughly estimated by a simultaneous visual assessment from the ground and the canopy. For each of the 10 sample palms, trunk height and DBH were measured and the number of leaves was counted. During the period of measurements, new leaves emerged and old ones were pruned by the farmers; we assumed the number of leaves per palm to be constant over time.

\subsubsection{Scheme for scaling up from leaves to stand}

Individual leaf water use $\left(Q, \mathrm{~kg} \mathrm{~d}^{-1}\right)$ rates were calculated by multiplying the respective integrated daily sap flux densities by water conductive areas; the $Q$ values of all leaves measured simultaneously were averaged to obtain the average leaf water use $\left(E_{\mathrm{L}}, \mathrm{kg} \mathrm{d}^{-1}\right)$. To scale up from leaves to stand water use, we used the following equation (adjusted from Granier et al., 1996b):

$$
E_{\mathrm{S}}=\frac{E_{\mathrm{L}} \times N_{\mathrm{L}} \times N_{\mathrm{p}}}{A_{\mathrm{g}}}=\frac{\left(\bar{J}_{\mathrm{S}} \times \bar{A}_{\mathrm{c}}\right) \times N_{\mathrm{L}} \times N_{\mathrm{p}}}{A_{\mathrm{g}}}
$$

Where $E_{\mathrm{s}}$ is the stand transpiration $\left(\mathrm{mm} \mathrm{d}^{-1}\right), E_{\mathrm{L}}\left(\mathrm{kg} \mathrm{d}^{-1}\right.$; equals $\left.\mathrm{mm} \mathrm{m}^{2} \mathrm{~d}^{-1}\right)$ is the average leaf water use as a product of average integrated daily sap flux density $\left(\bar{J}_{\mathrm{s}}, \mathrm{kg} \mathrm{cm}^{-2} \mathrm{~d}^{-1}\right)$ and average leaf water conductive area $\left(\bar{A}_{\mathrm{c}}, \mathrm{cm}^{2}\right) ; N_{\mathrm{L}}$ is the average number of leaves per palm; $N_{\mathrm{p}}$ is the number of palms per ground area $\left(A_{\mathrm{g}}, \mathrm{m}^{2}\right) . N_{\mathrm{p}}$ is constant and can be counted directly, i.e. the sources of error for estimates of $E_{\mathrm{s}}$ come from the estimates of $E_{\mathrm{L}}$ and $N_{\mathrm{L}}$ exclusively. 
(a)

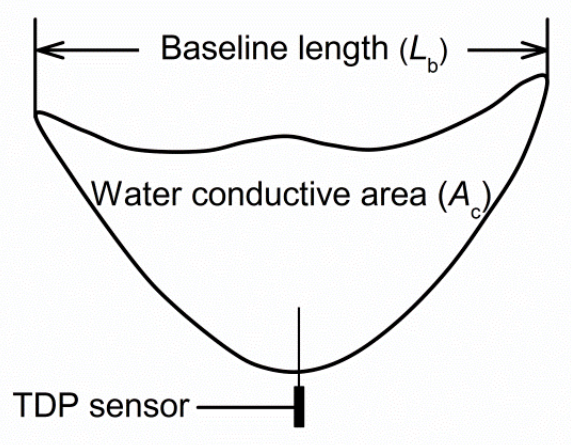

(b)

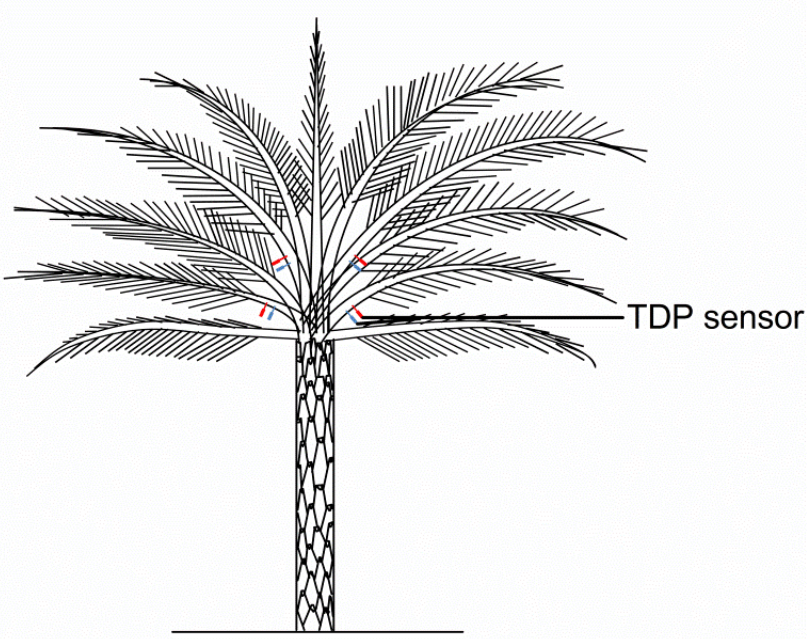

Figure 3.2 Cross-section of an oil palm petiole at location of probe installation (a) and installation of thermal dissipation probes (TDP) on oil palms in the field (b).

\subsubsection{Estimation errors associated with sample size}

The individual leaf water use $Q$ rates of 47 leaves (nine of 56 installed sensors excluded due to technical problems) on three sunny days (30 May-1 June 2013) were averaged for the analysis in order to minimize weather-induced variability among leaves. In a first step, we tested whether strata such as azimuthal orientation or trunk height had to be taken into account: for all measured field variables (leaf orientation, inclination and shading, trunk height and diameter), linear regressions were performed; multiple linear regressions were used to examine interactions. The $Q$ values of the different strata were compared with the Student's t-test. To test for normality of the distribution of $Q$ values, we performed the Shapiro-Wilk normality test. The distribution of the $Q$ values was normal, so that the relative standard error of the mean $\left(\mathrm{SE}_{\mathrm{n}}\right)$ serves as a measure of the estimation error associated with sample size. We calculated mean and standard deviation (SD) of the $Q$ values and normalized the $\mathrm{SD}$ by the mean to obtain the relative standard deviation $\left(\mathrm{SD}_{\mathrm{n}}\right)$. To examine how different sample sizes (i.e. number of leaves, $n$ ) affect the magnitude of the $\mathrm{SE}_{n}$, we used $n=1-47$ to calculate respective $\mathrm{SE}_{\mathrm{n}}$ values of $E_{\mathrm{L}}$ with the equation

$$
\mathrm{SE}_{\mathrm{n}}=\frac{\mathrm{SD}_{\mathrm{n}}}{\sqrt{n}}
$$

Where $\mathrm{SE}_{\mathrm{n}}$ is the relative standard error of the mean of $E_{\mathrm{L}}$ in dependence of the sample size $(n)$, and $\mathrm{SD}_{\mathrm{n}}$ is the relative standard deviation of $E_{\mathrm{L}}$ for the full sample of 47 leaves. 
We defined the statistically "optimal" sample size $\left(n_{\mathrm{o}}\right)$, to be that $n$, at which a further increase of $\mathrm{n}(\mathrm{d} n)$ results in only marginal gains of precision of the estimate of $E_{\mathrm{L}}$ (i.e. $\left.\mathrm{dSE}_{\mathrm{n}}>-0.5 \%\right)$. To derive $n_{\mathrm{o}}$ analytically, we set the first derivate of equation (4) equal to -0.005 (i.e. $-0.5 \%$ ) and solved it for $n_{\mathrm{o}}$ :

$$
n_{\mathrm{o}}=\left(\frac{\mathrm{SD}_{\mathrm{n}}}{0.01}\right)^{\frac{2}{3}}
$$

Where $\mathrm{SD}_{\mathrm{n}}$ is the relative standard deviation of $E_{\mathrm{L}}$ for the full sample of 47 leaves and $n_{\mathrm{o}}$ is the analytically-derived "optimal" sample size, where $\frac{\mathrm{dSE}_{\mathrm{n}}}{\mathrm{d} n}>-0.005$.

We counted the number of leaves per palm on our full sample of $m=10$ palms. Like $E_{\mathrm{L}}, N_{\mathrm{L}}$ was normally distributed, so that, in analogy to the procedure just explained for $E_{\mathrm{L}}$, an "optimal" sample size $\left(m_{\mathrm{o}}\right)$ for estimates of $N_{\mathrm{L}}$ could be derived. To quantify the total error in estimates of $E_{\mathrm{s}}$ it is assumed that the total variance around $E_{\mathrm{s}}$ is given by the combined variances of $E_{\mathrm{L}}$ and $N_{\mathrm{L}}$. Hence, as an estimate of the $\mathrm{SE}_{\mathrm{n}}$ of $E_{\mathrm{s}}$, we can add the respective $\mathrm{SE}_{\mathrm{n}}$ of $E_{\mathrm{L}}$ and $N_{\mathrm{L}}$ for any given combination of sample sizes (product rule), e.g. for the "optimal" sample sizes $n_{\mathrm{o}}$ and $m_{\mathrm{o}}$.

\subsubsection{Analyzing the environmental drivers of leaf water use}

To visualize and examine meteorological drivers of water use over a 90-day-period (3 July to 30 September 2013), daily $E_{\mathrm{L}}$ values were plotted against radiation and VPD. Normalized hourly values of $E_{\mathrm{L}}$ (average of three sunny days) were plotted against normalized radiation and VPD in order to examine the occurrence of hysteresis. All observations with a minimum of 13 TDP sensors running simultaneously were included in the analysis.

Statistical analyses were performed with R version 3.1.1 (R Development Core Team, 2014); for graphing, Origin 8.5 (Origin Lab, Northampton, MA, USA) was used. 


\subsection{Results}

\subsubsection{Calibration experiment}

We observed a linear relationship between $L_{\mathrm{b}}$ and $A_{\mathrm{c}}$ of oil palm petioles: $A_{\mathrm{c}}=3.95 L_{\mathrm{b}}-9.86\left(R^{2}=\right.$ $0.97, P<0.001$ ). Average vessel density was $45 \mathrm{~cm}^{-2}$, with an average within-segment coefficient of variation of $12 \%$ among ten $1 \mathrm{~cm}^{2}$ squares. Our estimates for the parameters of the calibration equation were $a=48.24$ and $b=1.60\left(R^{2} \mathrm{adj}=0.90, P<0.001\right)$, whereas the values by Granier (1985) were $a=42.84$ and $b=1.23$. The Wilcoxon signed-rank test suggested that $J_{\mathrm{s}}$ calculated with the original calibration equation (Granier, 1985) were significantly different $(P<0.05)$ from $J_{\mathrm{g}}$. Using the newly-derived parameters yielded $J_{\mathrm{s}}$ values that were not significantly different from $J_{\mathrm{g}}$ in $84 \%$ of 10,000 times. The linear relationship between $J_{\mathrm{s}}$ values derived from the original parameters (Figure 3.3a) and our new parameters (Figure 3.3b) with $J_{\mathrm{g}}$ was strong in both cases $\left(R^{2}>0.94, P<0.001, \mathrm{RMSE}=2.48\right.$ and 1.81 , respectively $)$; however, using the newly-derived parameters increased the precision of predictions from an overestimation of $17.3 \%$ (original parameters) to a slight underestimation of $1.6 \%$.
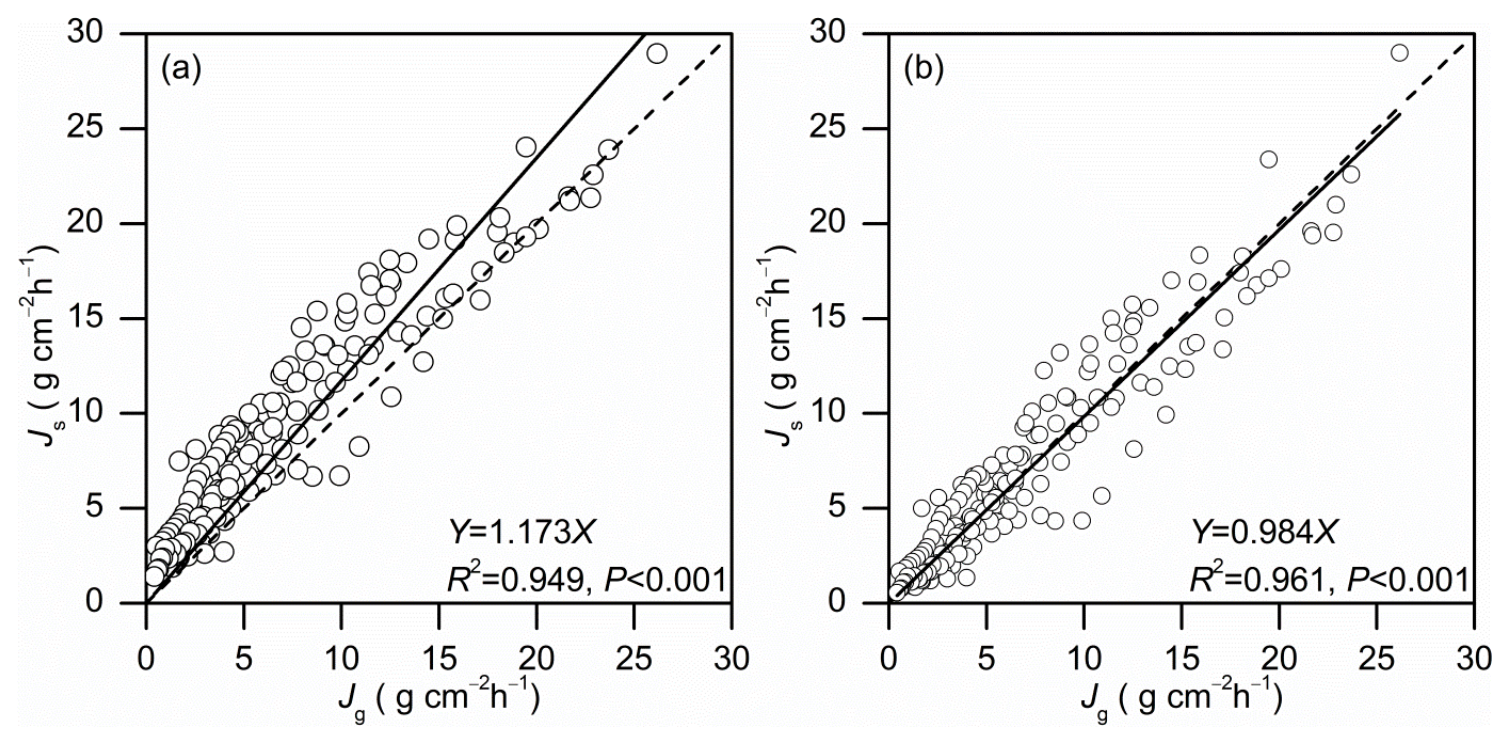

Figure 3.3 Sap flux densities derived from gravimetric measurements $\left(J_{\mathrm{g}}\right)$ and thermal dissipation probes $\left(J_{\mathrm{s}}\right)$ using the original parameters of the calibration equation (a) and our newly-derived parameters (b). Pooled data from eight oil palm segments, points represent 10-minute-averages, regression lines (solid lines) were forced through the origin, dashed lines indicate a 1:1 relationship. 


\subsubsection{Field study}

\subsubsection{Spatial variability of leaf water use}

Under sunny conditions (three days averaged), there was a 10-fold variation in $Q$ rates of 47 oil palm leaves, ranging from 0.5 to $4.9 \mathrm{~kg} \mathrm{~d}^{-1}$; average $Q$ was $2.5 \pm 1.1 \mathrm{~kg} \mathrm{~d}^{-1}$ (mean $\pm \mathrm{SD}$ ). Linear regressions suggest that there was no significant influence of the factors leaf orientation, inclination and estimated horizontal shading and of trunk diameter and height on $Q(P>0.5)$. Testing for interaction of these single factors with multiple linear regressions again revealed no significant influence of any combination of variables on $Q(P>0.5)$. The mean $Q$ values in different strata of leaf orientation $(\mathrm{N}, \mathrm{E}, \mathrm{S}, \mathrm{W})$, inclination $\left(<, \geq 60^{\circ}\right)$, shading $(<, \geq 50 \%)$ and trunk height $(<, \geq 4.5 \mathrm{~m})$ and diameter $(<, \geq 78 \mathrm{~cm})$ were not significantly different $(P>0.05$, Student's t-test).

\subsubsection{Sample size}

The analysis of potential estimation errors of $E_{\mathrm{L}}$ associated with sample size (i.e. the number of leaves measured, $n$ ) suggests that the $\mathrm{SE}_{\mathrm{n}}$ of $E_{\mathrm{L}}$ was high $\left(\mathrm{SE}_{\mathrm{n}}>30 \%\right)$ for very small samples ( $n \leq$ 2 ), but decreased relatively fast to a $\mathrm{SE}_{\mathrm{n}}$ of $11.7 \%$ at the statistically "optimal" sample size, $n_{\mathrm{o}}=$ 13. Further increasing $n$ improved the precision of estimation of $E_{\mathrm{L}}$ only under-proportionally (Figure 3.4a). As the number of leaves per palm only varied little between palms, the $\mathrm{SE}_{\mathrm{n}}$ of $N_{\mathrm{L}}$ was much lower $\left(\mathrm{SE}_{\mathrm{n}}<5 \%\right.$ ), even at small sample sizes (e.g. $m=1 \mathrm{palm}$ ); it decreased to $2.5 \%$ at the "optimal" sample size, $m_{\mathrm{o}}=4$ (Figure $3.4 \mathrm{~b}$ ). Assuming that the variance around the $E_{\mathrm{s}}$ estimate is given by the combined variances of the estimates of $E_{\mathrm{L}}$ and $N_{\mathrm{L}}$, we can provide $\mathrm{SE}_{\mathrm{n}}=$ $11.7+2.5=14.2 \%$ as an estimate for the total potential error in the estimate of $E_{\mathrm{s}}$ at $n_{\mathrm{o}}=13$ and $m_{\mathrm{o}}=4$. To decrease this total $\mathrm{SE}_{\mathrm{n}}$ further (e.g. $\mathrm{SE}_{\mathrm{n}}=10 \%$ ), much larger sample sizes for $n$ are necessary (e.g. $n=33, m=4$ ). The full available sample of 47 leaves and 10 palms resulted in a $\mathrm{SE}_{\mathrm{n}}$ of $E_{\mathrm{s}}$ of $6.5 \%$.

\subsubsection{Estimate of oil palm transpiration including error margins}

Average $E_{\mathrm{s}}$ during the 90 -day measurement period was $1.1 \mathrm{~mm} \mathrm{~d}^{-1}$, ranging from 0.5 to $1.3 \mathrm{~mm}$ $\mathrm{d}^{-1}$, based on a minimum number of 13 leaves measured simultaneously and a leaf count on 10 palms. Under such conditions, the assessment of estimation errors associated with sample sizes suggested a $\mathrm{SE}_{\mathrm{n}}$ of $E_{\mathrm{s}}$ of $13.3 \%$. This results in $1.1 \pm 0.2 \mathrm{~mm} \mathrm{~d}^{-1}$ as an estimate for $E_{\mathrm{s}}$ including standard error based error margins. The Penman-Monteith-derived estimate of stand evapotranspiration was $2.6 \mathrm{~mm} \mathrm{~d}^{-1}$ for the same period. 

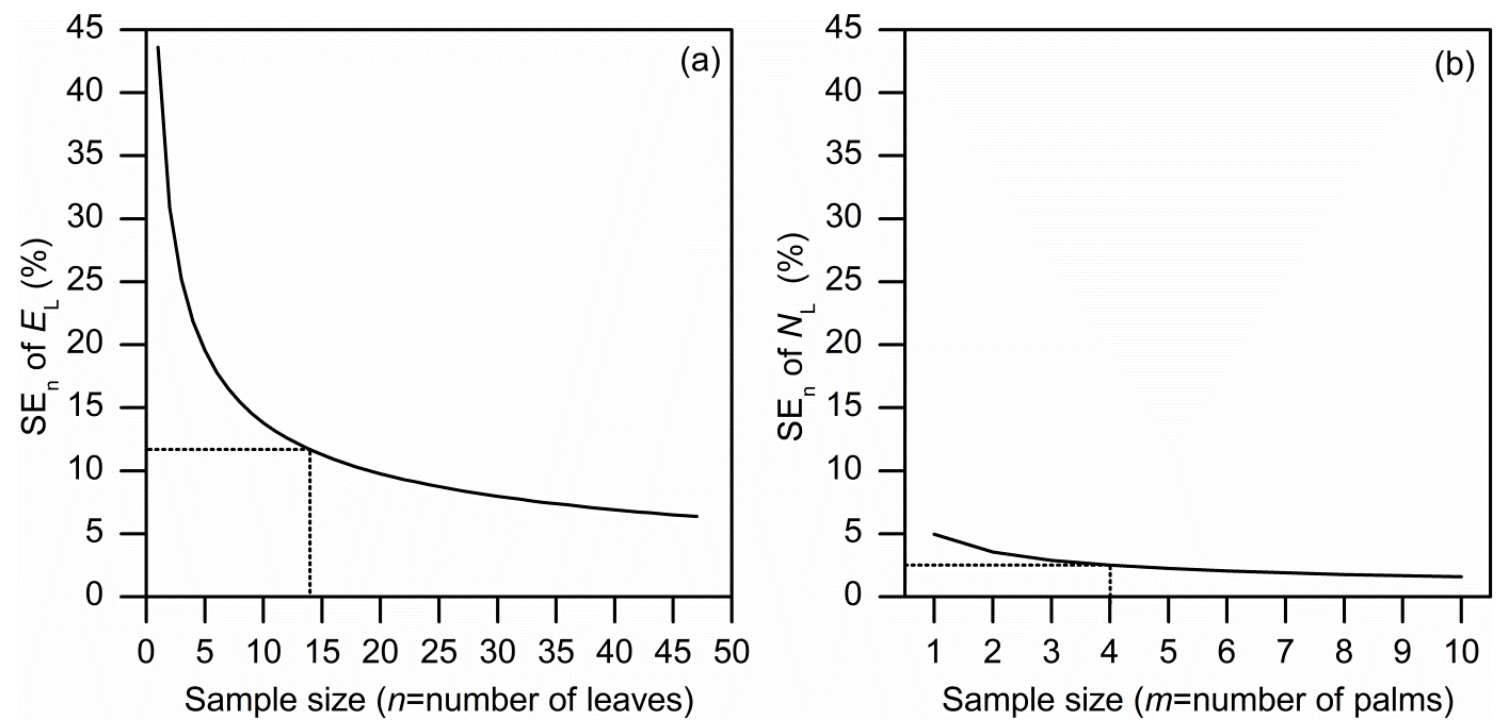

Figure 3.4 Relative standard error of the mean $\left(\mathrm{SE}_{\mathrm{n}}\right)$ of average leaf water use $\left(E_{\mathrm{L}}\right)$ (a) and of the average number of leaves per palm $\left(N_{\mathrm{L}}\right)$ (b) in dependence of sample size, the number of measured leaves $(n)$ and sampled palms $(m)$, respectively. The dotted lines indicate "optimal" sample sizes, at which $\frac{\mathrm{dSE}_{\mathrm{n}}}{\mathrm{d} n, \mathrm{~d} m}>-0.005$.
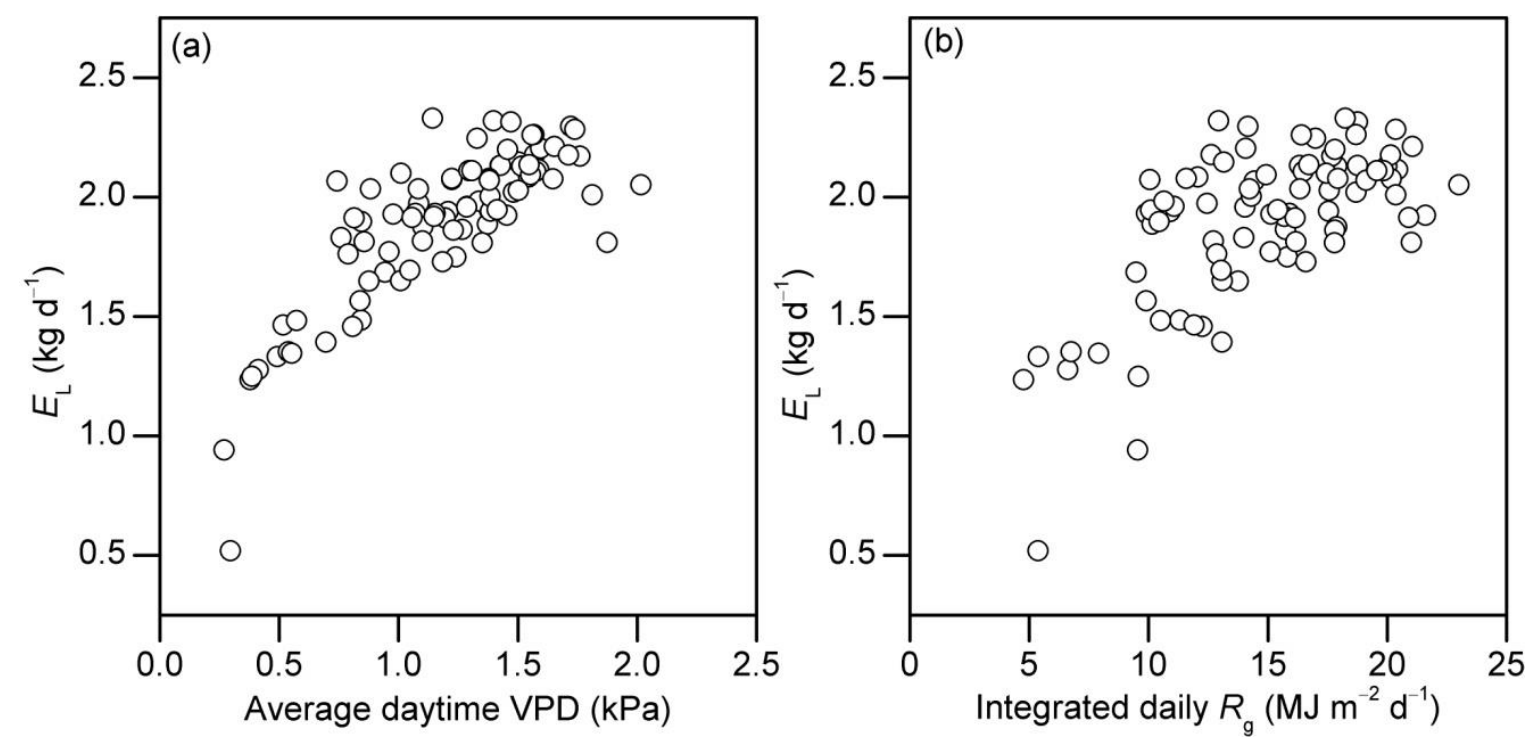

Figure 3.5 Average leaf water use $\left(E_{\mathrm{L}}\right)$ plotted against average daytime vapor pressure deficit (VPD) (a) and integrated daily radiation $\left(R_{\mathrm{g}}\right)(\mathrm{b})$. Data of 90 days, $E_{\mathrm{L}}$ estimates based on at least 13 leaves measured simultaneously. 

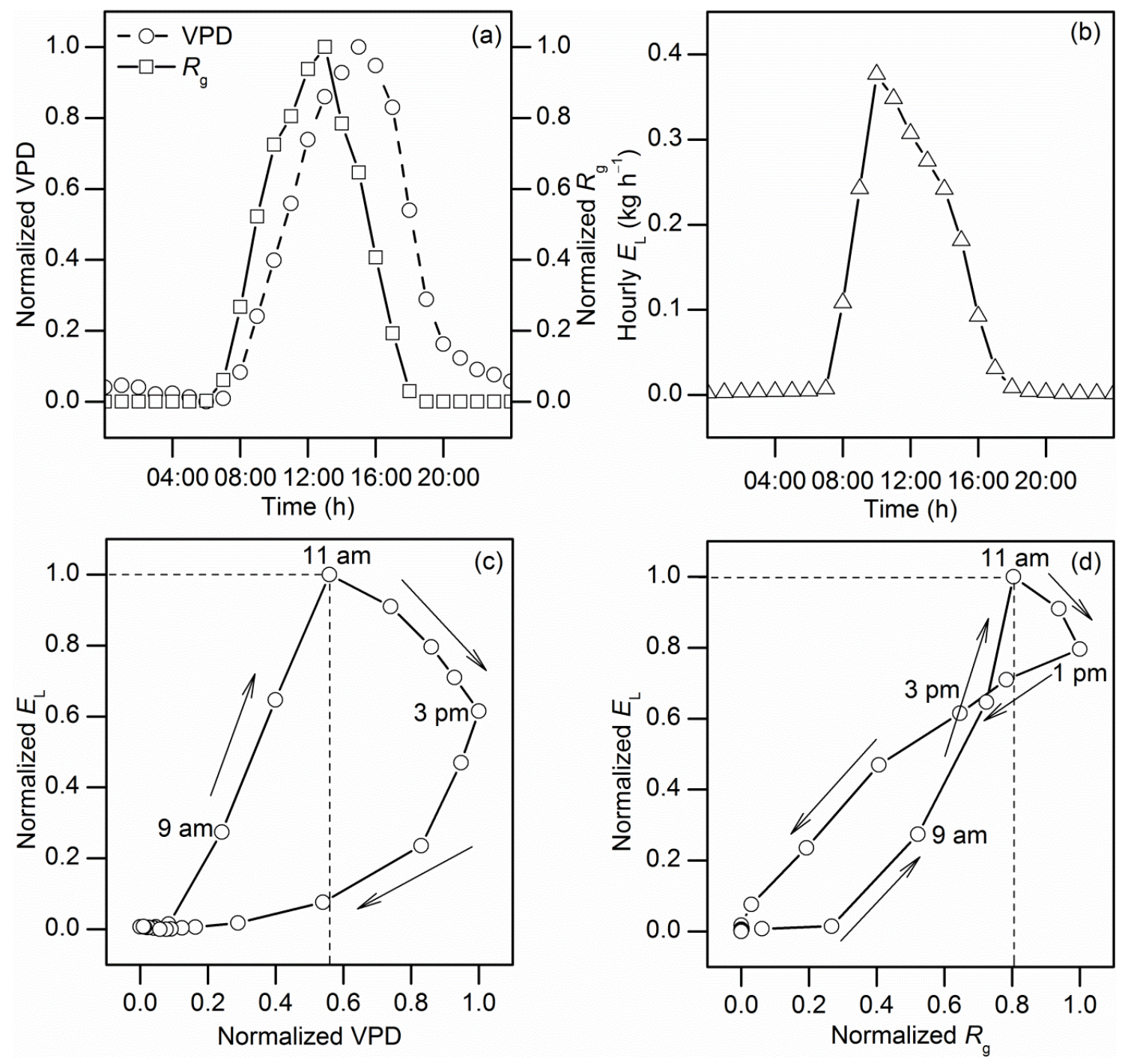

Figure 3.6 The diurnal courses of vapor pressure deficit (VPD) and radiation $\left(R_{\mathrm{g}}\right)(\mathrm{a})$ and of average leaf water use $\left(E_{\mathrm{L}}\right)(\mathrm{b})$. Normalized $E_{\mathrm{L}}$ plotted against normalized VPD (c) and normalized $R_{\mathrm{g}}(\mathrm{d})$. The points represent hourly means of three sunny days; the arrows indicate the direction in which the next consecutive observation in time occurred. $E_{\mathrm{L}}$ estimates based on at least 13 leaves measured simultaneously.

\subsubsection{Meteorological drivers of leaf water use}

The average leaf water use $E_{\mathrm{L}}$ rates over a 90-day-period was driven by the variables VPD and $R_{\mathrm{g}}$ (Figure 3.5); it leveled-off around $2.2 \mathrm{~kg} \mathrm{~d}^{-1}$, after rising almost linearly with increasing VPD and $R_{\mathrm{g}}$ before that.

The diurnal course of hourly $E_{\mathrm{L}}$ (averages of three sunny days) was also related to VPD and $R_{\mathrm{g}}$ (Figure 3.6), but we observed hysteresis in the $E_{\mathrm{L}}$ response to both of these variables. Maximum $E_{\mathrm{L}}$ rates were reached early in the day (around 11:00 am). After this early peak, $E_{\mathrm{L}}$ rates declined relatively consistently, despite rising levels of $R_{\mathrm{g}}$ and VPD. By the time $R_{\mathrm{g}}$ and VPD peaked, around $1 \mathrm{pm}$ and $3 \mathrm{pm}$, respectively, $E_{\mathrm{L}}$ was already reduced to about $80 \%$ and $60 \%$, respectively, 
of its maximum. Despite similar VPD levels, $E_{\mathrm{L}}$ rates were 10 -fold higher at their 11 am peak than in the late afternoon. Likewise but less pronounced, similar $R_{\mathrm{g}}$ levels resulted in $30 \%$ lower $E_{\mathrm{L}}$ rates in the early afternoon $(2 \mathrm{pm})$ than at the 11 am peak.

\subsection{Discussion}

\subsubsection{Calibration}

We used thermal dissipation probes (Granier, 1987, 1996a) to measure sap flux density in oil palms. We measured in leaf petioles rather than trunks because vessel density and size is presumably larger and vessels are presumably distributed more homogeneously (Parthasarathy and Klotz, 1976). Also, the large dimensions of oil palm trunks (up to $100 \mathrm{~cm} \mathrm{DBH)} \mathrm{make} \mathrm{an}$ assessment of the radial variability of sap flux density difficult. For other palm species, inhomogeneous radial patterns of sap flux density have been shown (Sellami and Sifaoui, 2003; Sperling et al., 2012). Within leaf petioles, variations in the vessel density $D_{\mathrm{v}}$ across the crosssectional area have been observed in some palm species (Parthasarathy and Klotz, 1976), suggesting a peripheral increase in $D_{\mathrm{v}}$ and a potentially lower $D_{\mathrm{v}}$ towards the center of the petiole. We did not find references for oil palm. TDP sensors are assumed to integrate variations in sap flux density along their length (Granier et al., 1994), which should account for variations in $D_{\mathrm{v}}$; however, this may not be the case if changes in sap flux density are abrupt (Clearwater et al., 1999).

To reduce the spatial variability of sap flux density and of water conducting properties along the sensor and thus enhance the precision of sap flux density estimates (Clearwater et al., 1999; James et al., 2002), we diverged from the Granier $(1987,1996 \mathrm{a})$ design with regard to probe length, reducing the number of windings of heating wire to 36 , half of the original design. As the Teflon coating around our constantan heating wire was marginally thicker than in the original design, the total length of our heating element was $12.5 \mathrm{~mm}$. Exploratory experiments showed, that differences in probe loading (i.e. power output per $\mathrm{cm}$ probe) as the result of such differences in obtainable materials for probe construction did not exceed $0.01 \mathrm{~W} \mathrm{~cm}^{-1}$.

Our calibration experiments yielded new parameters for the original calibration equation, which significantly improved the prediction of gravimetric measurements compared to the original parameters by Granier (1985). They reduced the divergence between TDP and gravimetric measurements from an overestimation of $17.3 \%$ (original parameters) to an underestimation of $1.6 \%$ (new parameters). The range of $J_{\mathrm{g}}$ in the calibration experiments covered the range of $J_{\mathrm{s}}$ observed under field conditions very well: despite an almost $40 \%$ higher maximum $J_{\mathrm{s}}$ value in the field, only $0.05 \%$ of the recorded data lay outside the $J_{\mathrm{g}}$ range we covered in the laboratory $\left(0-26.2 \mathrm{~g} \mathrm{~cm}^{-1} \mathrm{~h}^{-1}\right)$. Additionally, the relationship between $J_{\mathrm{s}}$ and $J_{\mathrm{g}}$ was clearly linear in the 
covered range; thus, we think an extrapolation of this relationship outside the observed range will most likely not induce large errors in estimates of $J_{\mathrm{s}}$.

There have been several studies where a species-specific calibration of the TDP method was performed by comparing sap flux densities derived from TDP measurements with gravimetrically-derived values or water flux rates established by other methods. Noncontradictory estimations utilizing the original calibration equation have been reported for some diffuse-porous tree species, but large underestimations became apparent for some ring-porous species (Bush et al., 2010). Substantial deviations from reference readings ( $+55 \%$ to $-34 \%$ ) were also reported when calibrating juvenile trees of six different tree species (Sun et al., 2012). For rainforest palms (Iriartea deltoidea Ruiz \& Pav.), larger values were obtained for the equation parameters ( $a$ and $b$ ) than by Granier (1985); however, the original equation yielded values that lay within the $95 \%$ confidence bands of the new calibration equation (Renninger et al., 2010). When comparing transpiration rates measured with a lysimeter to TDP-derived values for date palms, a $40 \%$ underestimation of sap flux density was reported with the original calibration equation (Sperling et al., 2012).

Possible reasons for the divergence between sap flux density estimates derived from the original calibration equation and reference measurements include physiological (e.g. heterogeneity of vessel density), technical (e.g. sensor type) and other methodological aspects (e.g. calibration setup). Our new parameters resulted in a slight underestimation of sap flux density of $1.6 \%$. However, a further validation of these new parameters, e.g. on potted oil palms with gravimetric measurements may be called for to further increase the confidence in their reliability.

\subsubsection{Spatial variability of leaf water use}

In the field study, we found a 10-fold variation in individual leaf water use $Q$ rates among 47 oil palm leaves under sunny conditions. On other palm species, five- to seven-fold variations have been observed between no more than 10 sample leaves (Renninger et al., 2009; Madurapperuma et al., 2009). In our study, leaf orientation, inclination and shading, and trunk height and diameter had no significant influence on $Q$. We found no other studies assessing influences of leaf orientation or shading on $Q$; regarding leaf inclination (as a measure of leaf age), young leaves of coco palms (Syagrus romanzoffiana Cham.) were reported to transpire at substantially (magnitude of $>7$ ) higher rates than old ones (Madurapperuma et al., 2009). For oil palm, a decline of photosynthesis rates over the lifespan of leaves, but little variability between leaves of the same age has been reported (Dufrene and Saugier, 1993), which might be contradictory to the results of our study. 
Given the close proximity of our study site to the equator ( $2^{\circ}$ South), the relatively short life span of oil palm leaves before being cut (five to 10 months) and the open and dome-shaped architecture of oil palm crowns, it seems reasonable that the variables leaf orientation, inclination and shading failed to explain the observed variability in $Q$. Trunk height also did not influence $Q$ in our study; similar findings have been reported for Mexican fan palms (Washingtonia filifera Linden ex André H Wendl.) (Renninger et al., 2009) and two Amazonian palm species (I. deltoidea and Mauritia flexuosa L.) (Renninger and Phillips, 2010). We found no statistical interaction of the five single factors leaf orientation, inclination and shading and trunk height and diameter that impact $Q$ (multiple linear regressions, $P>0.5$ for all combinations of variables). Possibly, some of the examined variables counteract over the lifespan of an oil palm leaf: very young leaves may have a higher water use per area of conductive tissue, but are small and hence have a relatively small cross-sectional conductive area; they are inclined more vertically, so they are shaded less, but also offer less horizontal area to absorb radiation.

\subsubsection{Error margins of stand transpiration and "optimal" sample sizes}

Based on the previously discussed results regarding the high, but unexplained variability in individual leaf water use values, we took an un-stratified approach to establish a statistically sound measurement scheme for estimating the stand transpiration $E_{\mathrm{s}}$ including error margins. The derived "optimal" sample sizes from an analysis of potential estimation errors of $E_{\mathrm{s}}$ associated with sample size were 13 leaves for estimating the average leaf water use and four palms for estimating the average leaf number per palm. Using larger samples improved the precision of estimates of $E_{\mathrm{s}}$ only marginally. Using the "optimal" sample sizes, the $\mathrm{SE}_{\mathrm{n}}$ of $E_{\mathrm{s}}$ as a measure for the potential total estimation error was $14 \%$. The $\mathrm{SE}_{\mathrm{n}}$ can be compared to, and in our case was similar to, coefficients of variation (CV) derived from numerical Monte Carlo analyses in other studies: in Japanese cypress (Chamaecyparis obtusa Siebold et Zucc. Endl.) monocultures, to achieve a $\mathrm{CV}$ of $E_{\mathrm{s}}$ of $18 \%$, recommend sample sizes were $i=15$ and $j=10$ for estimating sap flux density (on $i$ trees) and sapwood area (on $j$ trees) (Kume et al., 2010b). In a Moso bamboo (Phyllostachys pubescens Mazel ex J. Houz.) forest, sample sizes of $i=11$ and $j=12$ resulted in a total CV of $E_{\mathrm{s}}$ of $13 \%$ (Kume et al., 2010a). However, sample sizes likely have to be much larger than in these monoculture plantations when measuring spatially more heterogeneous stands (e.g. natural forests); small sample sizes may result in very high estimation errors (e.g. CV of $J_{\mathrm{s}}=40 \%$ at $i=8$, Granier et al., 1996c).

\subsubsection{Oil palm transpiration}

Our estimate for stand transpiration of oil palm $\left(1.1 \pm 0.2 \mathrm{~mm} \mathrm{~d}^{-1}\right.$; 90-day-mean $\left.\pm \mathrm{SD}\right)$ fell into the lower range of transpiration rates derived with similar techniques in tree-based tropical land- 
use systems (e.g. Cienciala et al., 2000; Dierick and Hölscher, 2009) and tropical forests (e.g. Becker, 1996; McJannet et al., 2007). Our micrometeorologically-derived estimate for evapotranspiration from the Penman-Monteith equation (FAO 56: Allen et al., 1998) was also relatively low $\left(2.6 \pm 0.7 \mathrm{~mm} \mathrm{~d}^{-1}, 90\right.$-day-mean $\left.\pm \mathrm{SD}\right)$, and does not contradict our transpiration value. The divergence between the two estimates can well be explained by the associated uncertainties and by the difference between palm transpiration and total evapotranspiration, the latter of which includes e.g. evaporation from the soil and, after rainfall events, from the palms and the epiphytes covering the trunks.

The relatively low stand transpiration values observed in our study could be due to the low stand density of 138 palms ha ${ }^{-1}$. The effects of stem density are e.g shown in a study comparing two Acacia mangium Willd. stands with 510 and 990 Acacia trees ha ${ }^{-1}$ on Borneo: the latter had a $70 \%$ higher transpiration rate (Cienciala et al., 2000). Also, oil palm plantations have a relatively small stand crown-projection area (M.M. Kotowska et al. unpublished data: 23\% gap fraction in the BO3 plot). Leaf area index also seems to be relatively low for oil palm stands ( $<4$ for mature plantations, Corley and Tinker, 2003). We used the methodology presented here in eight further medium-aged oil palm plantations in the lowlands of Jambi (A. Röll et al. unpublished data) and observed more than two-fold higher stand transpiration rates than in the $\mathrm{BO} 3$ plot under similar environmental conditions (dry, sunny days). This points to a considerable variability from plot to plot, the underlying reasons of which still need to be explored.

Plotted against VPD and radiation, the average leaf water use $E_{\mathrm{L}}$ levels-off at a certain level between days, here at about $2.2 \mathrm{~kg} \mathrm{~d}^{-1}$ (Figure 3.5). Such a response is known from other studies for VPD (O’Brien et al., 2004; Kume et al., 2010b) and has been shown at similar VPD levels as in our study for photosynthesis rates of oil palm leaves (Dufrene and Saugier, 1993). Radiation, however, often has a linear relationship with (tree) water use (O'Brien et al., 2004; Dierick and Hölscher, 2009). It seems that oil palm, on an inter-daily scale (daily averages of a 90-dayperiod), can achieve near-maximum rates of $E_{\mathrm{L}}$ even when VPD and $R_{\mathrm{g}}$ levels are not particularly high; on the other hand, better environmental conditions for transpiration (i.e. higher VPD and $R_{\mathrm{g}}$ levels) do not induce further increases in $E_{\mathrm{L}}$. This is indicative of a conservative behavior of the day-to-day oil palm transpiration response to environmental drivers.

To investigate this further, we examined the relationship between $E_{\mathrm{L}}$ and VPD and $R_{\mathrm{g}}$ on the intradaily scale (hourly averages of three sunny days, Figure $3.6 \mathrm{c}$ and d): The $E_{\mathrm{L}}$ response in the morning was very sensitive to increases in VPD, i.e. a two-fold increase in VPD resulted in a more than three-fold increase of $E_{\mathrm{L}}$ rates between 9 and $11 \mathrm{am}$; the $E_{\mathrm{L}}$ response to increases in $R_{\mathrm{g}}$, on the other hand, was conservative, i.e. $E_{\mathrm{L}}$ was still marginal at $8 \mathrm{am}$, when $R_{\mathrm{g}}$ had already reached $25 \%$ of its daily maximum. $E_{\mathrm{L}}$ rates peaked earlier $(11 \mathrm{am})$ than $R_{\mathrm{g}}(1 \mathrm{pm})$ and much 
earlier than VPD (3 pm); they subsequently declined consistently throughout the day, regardless of further rises in $R_{\mathrm{g}}$ and VPD levels. Considerable hysteresis effects were observed, particularly for VPD: at similar VPD levels (55\% of daily maximum), $E_{\mathrm{L}}$ rates were 10-fold higher at the 11 am maximum than in the late afternoon. Large hysteresis in the water use response to VPD have also been shown in other tropical species, for eucalyptus (e.g., Eucalyptus miniata Cunn. Ex Schauer and Eucalyptus tetrodonta F.Muell.) (O'Grady et al., 1999; Zeppel et al., 2004). The early peak of $E_{\mathrm{L}}$ rates, however, seems unusual. In other investigated tropical species, peaks in water use and $R_{\mathrm{g}}$ tend to coincide, or $R_{\mathrm{g}}$ peaks first (e.g. Zeppel et al., 2004; Horna et al., 2011); this is also true for tree-based land use systems in the research region (A. Röll et al., unpublished data). The pronounced hysteresis in the $E_{\mathrm{L}}$ response of oil palm to VPD as well as the unusually early peak and the subsequent steady decline of $E_{\mathrm{L}}$ rates regardless of VPD and radiation patterns may point to internal trunk water storage mechanisms. As we measured sap flux density on the leaf petioles, i.e. above the trunk, the high $E_{\mathrm{L}}$ rates at relatively low VPD and $R_{\mathrm{g}}$ levels may be made possible by trunk water storage and/or root pressure mechanisms; likewise, the steady decline in $E_{\mathrm{L}}$ rates after the 11 am peak could be explained by depleted trunk water storage reservoirs. In general, it seems that oil palms may not be able to react to e.g. high $R_{\mathrm{g}}$ or VPD levels at noon or in the afternoon. This buffered behavior of oil palm transpiration on the intradaily level may explain why oil palms do not seem to transpire past a certain threshold ("levelling-off") on the inter-daily scale: during many of the hours with potentially favorable environmental conditions, oil palms already transpire at substantially reduced rates due to yet unexplained factors.

\subsection{Conclusions}

New, oil-palm-petiole specific parameters for the original calibration equation were derived in laboratory experiments. They differ from the original parameters and may allow for a more precise estimation of sap flux density in oil palms using the TDP method.

In the field, the observed variation in individual leaf water use was high, but the underlying reasons remain unknown. An un-stratified analysis of potential estimation errors of stand transpiration associated with sample size suggests analytically derived "optimal" sample sizes of 13 leaves to determine average leaf water use and counting leaves on four palms to determine the average number of leaves per palm. The resulting relative standard error of the mean of stand transpiration was $14.2 \%$.

Our stand transpiration estimate for oil palm $\left(1.1 \mathrm{~mm} \mathrm{~d}^{-1}\right)$ seems relatively low in comparison to values reported from other studies for a variety of tropical land-use systems. An analysis of the environmental drivers of oil palm water use on the intra-daily scale suggests a strong difference to 
tropical tree species. In the morning, water use rates reacted very sensitively to increases in vapor pressure deficit; they increased rapidly and reached their maximum early in the day (11 am). However, water use rates started to decline consistently after this early peak, despite further rises in vapor pressure deficit and radiation levels. This may be responsible for the observed uncoupled day-to-day behavior of oil palm transpiration from fluctuations in vapor pressure deficit and radiation levels.

\section{Acknowledgements}

The authors thank the editor and the anonymous reviewers for excellent suggestions and detailed, constructive criticism. We also thank Pak Heri Junedi and Pak Agusta Herdhata for their kind cooperation in the project. The authors thank Pak Dodo Gunawan from BMKG for long-term climate data. The authors thank M. M. Kotowska et al. for stand structural and managementrelated data and K. Allen et al. and S. Kurniawan et al. for information on soil characteristics. Our field assistants Bayu and Ferry were a great support at all times. Terima kasih!

\section{References}

Allen, R.G., Pereira, L.S., Raes, D., Smith, M., 1998. Crop evapotranspiration-guidelines for computing crop water requirements-FAO Irrigation and Drainage Paper 56. Food and Agriculture Organization of the United Nations, Rome.

Becker, P., 1996. Sap flow in Bornean heath and dipterocarp forest trees during wet and dry periods. Tree Physiology, 16, 295-299.

Bush, S.E., Hultine, K.R., Sperry, J.S., Ehleringer, J.R., 2010. Calibration of thermal dissipation sap flow probes for ring- and diffuse-porous trees. Tree Physiology, 30, 1545-1554.

Carr, M.K.V., 2011. The water relations and irrigation requirements of oil palm (Elaeis guineensis): a review. Experimental Agriculture, 47, 629-652.

Cienciala, E., Kučera, J., Malmer, A., 2000. Tree sap flow and stand transpiration of two Acacia mangium plantations in Sabah, Borneo. Journal of Hydrology, 236, 109-120.

Clearwater, M.J., Meinzer, F.C., Andrade, J.L., Goldstein, G., Holbrook, N.M., 1999. Potential errors in measurement of nonuniform sap flow using heat dissipation probes. Tree Physiology, 19, 681-687.

Corley, R.H.V., Tinker, P.B., 2003. The Oil Palm, Fourth Edition, Blackwell Science Ltd., Oxford, UK.

Dierick, D., Hölscher, D., 2009. Species-specific tree water use characteristics in reforestation stands in the Philippines. Agricultural and Forest Meteorology, 149, 1317-1326.

Dierick, D., Hölscher, D., Schwendenmann, L., 2010. Water use characteristics of a bamboo species (Bambusa blumeana) in the Philippines. Agricultural and Forest Meteorology, 150, 1568-1578. 
Dufrene, E., Saugier, B., 1993. Gas exchange of oil palm in relation to light, vapour pressure deficit, temperature and leaf age. Functional Ecology, 97-104.

FAO, 2014. FAOSTAT Production Statistics. Food and Agricultural Organization of the United Nations, Rome.

James, S.A., Clearwater, M.J., Meinzer, F.C., Goldstein, G., 2002. Heat dissipation sensors of variable length for the measurement of sap flow in trees with deep sapwood. Tree Physiology, 22, 277-283.

Horna, V., Schuldt, B., Brix, S., Leuschner, C., 2011. Environment and tree size controlling stem sap flux in a perhumid tropical forest of Central Sulawesi, Indonesia. Annals of Forest Science, 68, 1027-1038.

Granier, A., 1985. Une nouvelle méthode pour la mesure du flux de sève brute dans le tronc des arbres. Annals of Forest Science, 42, 193-200.

Granier, A., 1987. Evaluation of transpiration in a Douglas-fir stand by means of sap flow measurements. Tree Physiology, 3, 309-320.

Granier, A., Anfodillo, T., Sabatti, M., Cochard, H., Dreyer, E., Tomasi, M., Valentini, R., Bréda, N., 1994. Axial and radial water flow in the trunks of oak trees: a quantitative and qualitative analysis. Tree Physiology, 14, 1383-1396.

Granier, A., 1996a. Sap flow measurements using the radial flowmeter technique. INRA-Unité d'Ecophysiologie Forestiére, Champenoux, 1-9

Granier, A., Biron, P., Köstner, B., Gay, L.W., Najjar, G., 1996b. Comparisons of xylem sap flow and water vapour flux at the stand level and derivation of canopy conductance for Scots pine. Theoretical and Applied Climatology, 53, 115-122.

Granier, A., Huc, R., Barigah, S.T., 1996c. Transpiration of natural rain forest and its dependence on climatic factors. Agricultural and Forest Meteorology, 78, 19-29.

Kallarackal, J., Jeyakumar, P., Jacob, G.S., 2004. Water use of irrigated oil palm at three different arid locations in Peninsular India. Journal of Oil Palm Research, 16, 45-53.

Kume, T., Onozawa, Y., Komatsu, H., Tsuruta, K., Shinohara, Y., Umebayashi, T., Otsuki, K., 2010a. Stand-scale transpiration estimates in a Moso bamboo forest: (I) Applicability of sap flux measurements. Forest Ecology and Management, 260, 1287-1294.

Kume, T., Tsuruta, K., Komatsu, H., Kumagai, T.O., Higashi, N., Shinohara, Y., Otsuki, K., 2010b. Effects of sample size on sap flux-based stand-scale transpiration estimates. Tree Physiology, 30, 129-138.

Kunert, N., Schwendenmann, L., Potvin, C., Hölscher, D., 2012. Tree diversity enhances tree transpiration in a Panamanian forest plantation. Journal of Applied Ecology, 49, 135-144.

Madurapperuma, W.S., Bleby, T.M., Burgess, S.S.O., 2009. Evaluation of sap flow methods to determine water use by cultivated palms. Environmental and Experimental Botany, 66, 372-380.

McJannet, D., Fitch, P., Disher, M., Wallace, J., 2007. Measurements of transpiration in four tropical rainforest types of north Queensland, Australia. Hydrological Processes, 21, $3549-3564$.

O'Brien, J.J., Oberbauer, S.F., Clark, D.B., 2004. Whole tree xylem sap flow responses to multiple environmental variables in a wet tropical forest. Plant, Cell \& Environment, 27, 551-567.

Oishi, A.C., Oren, R., Stoy, P.C., 2008. Estimating components of forest evapotranspiration: a footprint approach for scaling sap flux measurements. Agricultural and Forest Meteorology, 148, 1719-1732. 
O’Grady, A.P., Eamus, D., Hutley, L.B., 1999. Transpiration increases during the dry season: patterns of tree water use in eucalypt open-forests of northern Australia. Tree Physiology, 19, 591-597.

Parthasarathy, M.V., Klotz, L.H., 1976. Palm “wood”. Wood Science Technology, 10, 247-271.

R Development Core Team, 2014. R: a language and environment for statistical computing. R Foundation for Statistical Computing, Vienna, Austria.

Radersma, S., de Ridder, N., 1996. Computed evapotranspiration of annual and perennial crops at different temporal and spatial scales using published parameter values. Agricultural Water Management, 31, 17-34.

Renninger, H.J., Phillips, N., 2010. Intrinsic and extrinsic hydraulic factors in varying sizes of two Amazonian palm species (Iriartea deltoidea and Mauritia flexuosa) differing in development and growing environment. American Journal of Botany, 97, 1926-1936.

Renninger, H.J., Phillips, N., Hodel, D.R., 2009. Comparative hydraulic and anatomic properties in palm trees (Washingtonia robusta) of varying heights: implications for hydraulic limitation to increased height growth. Trees, 23, 911-921.

Renninger, H.J., Phillips, N., Salvucci, G.D., 2010. Wet- vs. dry-season transpiration in an Amazonian rain forest Palm Iriartea deltoidea. Biotropica, 42, 470-478.

Roupsard, O., Bonnefond, J.M., Irvine, M., Berbigier, P., Nouvellon, Y., Dauzat, J., Taga, S., Hamel, O., Jourdan, C., Saint-André, L., et al., 2006. Partitioning energy and evapotranspiration above and below a tropical palm canopy. Agricultural and Forest Meteorology, 139, 252-268.

Sellami, M.H., Sifaoui, M.S., 2003. Estimating transpiration in an intercropping system: measuring sap flow inside the oasis. Agricultural Water Management, 59, 191-204.

Sperling, O., Shapira, O., Cohen, S., Tripler, E., Schwartz, A., Lazarovitch, N., 2012. Estimating sap flux densities in date palm trees using the heat dissipation method and weighing lysimeters. Tree Physiology, 32, 1171-1178.

Steppe, K., De Pauw, D.J.W., Doody, T.M., Teskey, R.O., 2010 A comparison of sap flux density using thermal dissipation, heat pulse velocity and heat field deformation methods. Agricultural and Forest Meteorology, 150, 1046-1056.

Sun, H., Aubrey, D.P., Teskey, R.O., 2012. A simple calibration improved the accuracy of the thermal dissipation technique for sap flow measurements in juvenile trees of six species. Trees, 26, 631-640.

Wilson, K.B., Hanson, P.J., Mulholland, P.J., Baldocchi, D.D., Wullschleger, S.D., 2001. A comparison of methods for determining forest evapotranspiration and its components: sap-flow, soil water budget, eddy covariance and catchment water balance. Agricultural and Forest Meteorology, 106, 153-168.

Zeppel, M.J., Murray, B.R., Barton, C., Eamus, D., 2004. Seasonal responses of xylem sap velocity to VPD and solar radiation during drought in a stand of native trees in temperate Australia. Functional Plant Biology, 31, 461-470.

Zwieniecki, M.A., Melcher, P.J., Holbrook, N.M., 2001. Hydrogel control of xylem hydraulic resistance in plants. Science, 291, 1059-1062. 


\section{CHAPTER 4}

\section{TRANSPIRATION IN AN OIL PALM LANDSCAPE: EFFECTS OF PALM AGE}

Alexander Röll ${ }^{1^{*} \dagger}$, Furong Niu ${ }^{1 *}$, Ana Meijide ${ }^{2}$, Afik Hardanto ${ }^{1,3}$, Hendrayanto ${ }^{4}$, Alexander Knohl ${ }^{2}$, Dirk Hölscher ${ }^{1}$

* The authors contributed equally to this work.

1 Tropical Silviculture and Forest Ecology, Georg-August-Universität Göttingen, Germany

2 Bioclimatology, Georg-August-Universität Göttingen, Germany

3 Universitas Jenderal Soedirman, Indonesia

4 Department of Forest Management, Institut Pertanian Bogor, Indonesia

† Correspondence to: Alexander Röll, Tropical Silviculture and Forest Ecology, Georg-AugustUniversität Göttingen, Büsgenweg 1, 37077 Göttingen, Germany. E-mail: aroell@gwdg.de

Published in Biogeosciences (2015) 12: 5619-5633, doi: 10.5194/bg-12-5619-2015 


\begin{abstract}
Oil palm (Elaeis guineensis Jacq.) plantations cover large and continuously increasing areas of humid tropical lowlands. Landscapes dominated by oil palms usually consist of a mosaic of mono-cultural, homogeneous stands of varying age, which may be heterogeneous in their water use characteristics. However, studies on the water use characteristics of oil palms are still at an early stage and there is a lack of knowledge on how oil palm expansion will affect the major components of the hydrological cycle. To provide first insights into hydrological landscape-level consequences of oil palm cultivation, we derived transpiration rates of oil palms in stands of varying age, estimated the contribution of palm transpiration to evapotranspiration, and analyzed the influence of fluctuations in environmental variables on oil palm water use. We studied 15 two- to 25 -year old stands in the lowlands of Jambi, Indonesia. A sap flux technique with an oil palm specific calibration and sampling scheme was used to derive leaf-, palm- and stand-level water use rates in all stands under comparable environmental conditions. Additionally, in a two- and a 12-year old stand, eddy covariance measurements were conducted to derive evapotranspiration rates. Water use rates per leaf and palm increased 5-fold from an age of two years to a stand age of approx. 10 years and then remained relatively constant. A similar trend was visible, but less pronounced, for estimated stand transpiration rates of oil palms; they varied 12-fold, from $0.2 \mathrm{~mm} \mathrm{~d}^{-1}$ in a 2-year old to $2.5 \mathrm{~mm} \mathrm{~d}^{-1}$ in a 12-year old stand, showing particularly high variability in transpiration rates among medium-aged stands. Comparing sap flux and eddycovariance derived water fluxes suggests that transpiration contributed $8 \%$ to evapotranspiration in the 2-year old stand and 53\% in the 12-year old stand, indicating variable and substantial additional sources of evaporation, e.g. from the soil, the ground vegetation and from trunk epiphytes. Diurnally, oil palm transpiration rates were characterized by an early peak between 10 and 11 am; there was a pronounced hysteresis in the leaf water use response to changes in vapor pressure deficit for all palms of advanced age. On the day-to-day basis this resulted in a relatively low variability of oil palm water use regardless of fluctuations in vapor pressure deficit and radiation. We conclude, that oil palm dominated landscapes show some spatial variations in (evapo)transpiration rates, e.g. due to varying age-structures, but that the temporal variability of oil palm transpiration is rather low. The stand transpiration of some of the studied oil palm stands was as high or even higher than values reported for different tropical forests, indicating a high water use of oil palms under yet to be explained site or management conditions. Our study provides first insights into the eco-hydrological characteristics of oil palms as well as a first estimate of oil palm water use across a gradient of plantation age. It sheds first light on some of the hydrological consequences of the continuing expansion of oil palm plantations.
\end{abstract}

Keywords: Chrono-sequence, evapotranspiration, eddy covariance, sap flux, Granier-type thermal dissipation probes 


\subsection{Introduction}

Oil palm (Elaeis guineensis Jacq.) has become the most rapidly expanding crop in tropical countries over the past decades, particularly in South East Asia (FAO, 2014). Asides from losses of biodiversity and associated ecosystem functioning (e.g. Barnes et al., 2014), potentially negative consequences of the expansion of oil palm cultivation on components of the hydrological cycle have been reported (e.g. Banabas et al., 2008). Only few studies have dealt with the water use characteristics of oil palms so far (Comte et al., 2012). Available evapotranspiration estimates derived from micrometeorological or catchment-based approaches range from 1.3 to $6.5 \mathrm{~mm} \mathrm{~d}^{-1}$ for different tropical locations and climatic conditions (e.g. Radersma and Ridder, 1996; Henson and Harun, 2005). However, various components of the water cycle under oil palm yet remain to be studied for a convincing hydrological assessment of the hydrological consequences of oil palm expansion, e.g. regarding the partitioning of the central water flux of evapotranspiration into transpirational and evaporative fluxes.

Landscapes dominated by oil palms are not necessarily homogeneous in their water use characteristics. Oil palms are usually planted in mono-specific and even-aged stands; commonly, stands are cleared and replanted at an age of approx. 25 years due to difficulties in harvesting operations, potentially declining yields and the opportunity to plant higher yielding varieties of oil palm. This creates a mosaic of stands of varying age, and hence with possibly different hydrological characteristics.

Substantial differences in transpiration rates of dicot tree stands have been shown for stands of varying age in several studies (e.g. Jayasuriya et al., 1993; Roberts et al., 2001; Vertessy et al., 2001; Delzon and Loustau, 2005); commonly, water use increases rapidly after stand establishment, reaching a peak after some decades (which is associated with high stand productivity and high stand densities) before declining more or less consistently with increasing age. This has e.g. been demonstrated for Eucalyptus regnans F. Muell. (Cornich and Vertessy, 2001), Eucalyptus sieberi L. Johnson (Roberts et al., 2001) and Pinus pinaster Aiton (Delzon and Loustau, 2005) for stands between 10 and 160 years old. Declines in transpiration rates in older stands were mainly explained by decreasing leaf and sapwood area with increasing stand age (Roberts et al., 2001; Vertessy et al., 2001; Delzon and Loustau, 2005). This may not be the case in palms, as at least at the individual level, for two Amazonian palm species (Iriartea deltoidea Ruiz \& Pav. and Mauritia flexuosa L.) linear increases of water use with increasing height, and hence age, have been demonstrated (Renninger et al., 2009, 2010).

Water use patterns over a gradient of plantation age to our knowledge have not yet been studied for oil palms. Water use could increase or decline with increasing stand age or could remain relatively 
stable from a certain age. Reasons for declining water use at a certain age include decreasing functionality of trunk xylem tissue with increasing age due to the absence of secondary growth in monocot species (Zimmermann, 1973), a variety of other hydraulic limitations (see review of dicot tree studies in Ryan et al., 2006) and increased hydraulic resistance due to increased pathway length with increasing trunk height (Yoder et al., 1994). However, for Mexican fan palms (Washingtonia robusta Linden ex André H Wendl.), no evidence of increasing hydraulic limitations with increasing palm height was found (Renninger et al., 2009). Reasons for potentially increasing water use in older plantations e.g. include linearly increasing oil palm trunk height with increasing palm age (Henson and Dolmat, 2003). As trunk height and thus volume increase, internal water storages probably also increase, possibly enabling larger (i.e. older) oil palms to transpire at higher rates (Goldstein et al., 1998; Madurapperuma et al., 2009). Additionally, increased stand canopy height is expected to result in an enhanced turbulent energy exchange with the atmosphere, i.e. a closer coupling of transpiration to environmental drivers, which can facilitate higher transpiration rates under optimal environmental conditions (Hollinger et al., 1994; Vanclay, 2009). The mentioned reasons for possibly increasing and decreasing water use with increasing plantations age, respectively, could also partly outbalance each other, or could be outbalanced by external factors (e.g. management related), potentially leading to no clear trend of oil palm transpiration over plantation age.

To investigate the water use characteristics of oil palm stands of varying age, we derived leaf-, palmand stand-scale transpiration estimates from sap flux density measurements with thermal dissipation probes (TDP; Granier, 1985) in 15 different stands (2-25 years old) in the lowlands of Jambi, Sumatra, Indonesia. We used the oil palm specific calibration equation and field measurement scheme recently proposed by Niu et al. (2015). Additionally, in two of these stands (two and 12 years old) we used the eddy covariance technique (Baldocchi, 2003) to derive independent estimates of evapotranspiration rates. For comparative purposes, the measurements were conducted under similar environmental conditions and partly simultaneously. Our objectives were (1) to derive transpiration rates of oil palms in stands of varying age, (2) to estimate the contribution of palm transpiration to total evapotranspiration, and (3) to analyze the influence of micro-meteorological drivers on oil palm water use. The study provides some first insights into the eco-hydrological characteristics of oil palms at varying spatial (i.e. from leaf to stand) and temporal (i.e. from hourly to daily) scales as well as first estimates of oil palm stand transpiration rates and their contribution to total evapotranspiration. It assesses some of the potential hydrological consequences of oil palm expansion on main components of the water cycle at the stand level. 


\subsection{Methods}

\subsubsection{Study sites}

The field study was conducted in Jambi, Sumatra, Indonesia (Figure 4.1). Between 1991 and 2011, average annual temperature in the region was $26.7 \pm 0.2{ }^{\circ} \mathrm{C}(1991-2011$ mean $\pm \mathrm{SD})$, with little intraannual variation. Annual precipitation was $2235 \pm 385 \mathrm{~mm}$, a dry season with less than $120 \mathrm{~mm}$ monthly precipitation usually occurred between June and September. However, the magnitude of dry season rainfall patterns varied highly between years (data from Airport Sultan Thaha in Jambi). Soil types in the research region are mainly sandy and clay Acrisols (Allen et al., 2015). We had research plots in a total of 15 different oil palm stands (Table 4.1), 13 of which were small holder plantations and two of which were properties of big companies. The stands were spread over two landscapes in the Jambi province (i.e. the Harapan and Bukit Duabelas regions, Figure 4.1), were all at similar altitude (60 $\mathrm{m} \pm 15 \mathrm{~m}$ a.s.l.) and belonged to the larger experimental set-up of the CRC990 (www.unigoettingen.de/crc990, Drescher et al., 2016). Stand age ranged from 2 to 25 years. Management intensity and frequency (i.e. fertilizer and herbicide application, manual and chemical weeding of ground vegetation and clearing of trunk epiphytes) varied considerably among the examined oil palm stands, but both were generally higher in larger plantations, particularly in PTPN6.

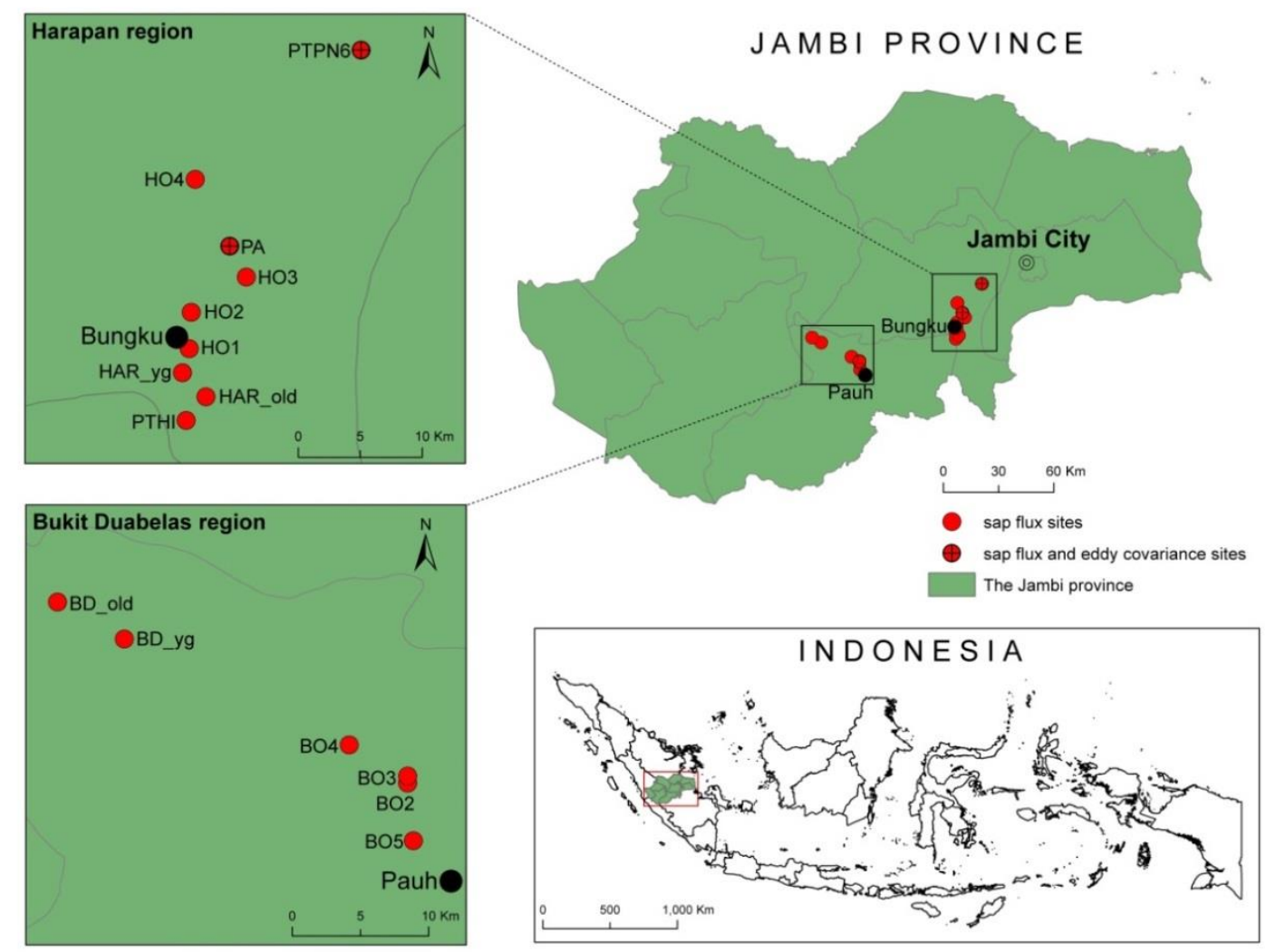

Figure 4.1 Locations of the studied oil palm stands in Jambi province, Sumatra, Indonesia. 


\subsubsection{Sap flux measurements and transpiration}

Following a methodological approach for sap flux measurements on oil palms (Niu et al., 2015), we installed thermal dissipation probe (TDP, Granier, 1985; Uniwerkstätten Universität Kassel, Germany; see Niu et al. 2015 for technical specifications) sensors in the leaf petioles of 16 leaves, four each on four different palms, for each of the 15 examined stands. Insulative materials and aluminum foil shielded the sensors to minimize temperature gradients and reflect radiation. Durable plastic foil was added for protection from rain. The sensors were connected to AM16/32 multiplexers connected to a CR1000 data logger (both Campbell Scientific Inc., Logan, USA). The signals from the sensors were recorded every $30 \mathrm{sec}$ and averaged and stored every $10 \mathrm{~min}$. The $\mathrm{mV}$-data from the logger was converted to sap flux density $\left(\mathrm{g} \mathrm{cm}^{-2} \mathrm{~h}^{-1}\right)$ with the empirically-derived calibration equation by Granier (1985), but with a set of equation parameters $a$ and $b$ that was specifically derived for TDP measurements on oil palm leaf petioles (Niu et al., 2015).

Individual leaf water use rates were calculated by multiplying respective sap flux densities (e.g. hourly averages, day sums) by the water conductive areas of the leaves; the water use values of all individual leaves measured simultaneously (min. 13 leaves) were averaged $\left(\mathrm{kg} \mathrm{d}^{-1}\right)$. To scale up to average palm water use $\left(\mathrm{kg} \mathrm{d}^{-1}\right)$, average leaf water use rates were multiplied by the average number of leaves per palm. Multiplying the average palm water use by the number of palms per unit of land $\left(\mathrm{m}^{2}\right)$ yielded stand transpiration rates $\left(T ; \mathrm{mm} \mathrm{d}^{-1}\right)$.

The sap flux measurements were conducted between April 2013 and December 2014, for a minimum of 3 weeks per study plot (Table 4.1). Three of the plots (BO3, PA, and PTPN6) ran over several months, partly in parallel to other plots. Most measurements, however, were conducted successively and thus partly took place under varying weather conditions. Thus, to minimize day-to-day variability introduced by varying weather for the analysis of effects of stand age on water use at different spatial scales, we used the average of three comparably sunny and dry days from the measurement period of each stand. Exploratory analyses had shown than unexplained variability was lower on sunny days than e.g. on cloudy or intermediate days or when using the averages of the full respective measurement periods. We chose days with a daily integrated radiation of more than $17 \mathrm{MJ} \mathrm{m}^{-2} \mathrm{~d}^{-1}$ and an average daytime VPD of more than $1.1 \mathrm{kPa}$; respective averages (mean $\pm \mathrm{SD}$ ) of all days included in the analysis were $20.3 \pm 2.6 \mathrm{MJ} \mathrm{m}^{-2} \mathrm{~d}^{-1}$ and $1.6 \pm 0.3 \mathrm{kPa}$ (also see Table 4.1).

\subsubsection{Stand structural characteristics}

For all sample leaves, the leaf petiole baseline length was measured between upper and lower probe of each TDP sensor installed in the field; this allowed calculating the water conductive area of each leaf (Niu et al., 2015). For each sample palm, trunk height to the youngest leaf (m) and diameter at breast 
height $(\mathrm{cm})$ were measured (see Kotowska et al., 2015 for detailed methodology) and the number of leaves per palm was counted. Over time, new leaves emerged and old ones were pruned by the farmers; we assumed the number of leaves per palm to be constant over our measurement period. On the stand level, we counted the number of palms per hectare.

\subsubsection{Eddy covariance measurements and evapotranspiration}

The eddy covariance technique (Baldocchi, 2003) was used to measure evapotranspiration $\left(E_{\mathrm{T}}, \mathrm{mm}\right.$ $\mathrm{d}^{-1}$ ) in two of the 15 oil palm stands, the 2-year-old (PA) and the 12-year-old (PTPN6) stand (Table 4.1). Towers of $7 \mathrm{~m}$ and $22 \mathrm{~m}$ in height, respectively, were equipped with a sonic anemometer (Metek uSonic-3 Scientific, Elmshorn, Germany) to measure the three components of the wind vector, and an open path carbon dioxide and water analyzer (Li-7500A, Licor Inc., Lincoln, USA) to derive evapotranspiration rates (Meijide et al., in review). Fluxes were calculated with the software EddyPro (Licor Inc.), planar-fit coordinate rotated, corrected for air density fluctuation and quality controlled. Thirty-minute flux data were flagged for quality applying the steady state and integral turbulence characteristic tests (Mauder and Foken, 2006). Data were also filtered according to friction velocity to avoid the possible underestimation of fluxes in stable atmospheric conditions. Energy balance closure for the EC sites was 73 and $84 \%$ for the 2-year-old (PA) and the 12-year-old stands. Data used for this analysis were not gap-filled. We selected three days when most of the thirty-minute measurements during the day where available. When a single thirty-minute value was missing, the value was filled by linear interpolation between the previous and the next $30 \mathrm{~min}$ value. Measurements were conducted between July 2013 and February 2014 in the 2-year old and from March to December 2014 in the 12-year old stand. For the analysis, we used the average of the same three sunny days that were selected for the sap flux analysis in the respective plots (see sap flux measurements and transpiration). Daytime (6 am-7 pm) evapotranspiration rates were used for the analyses and comparison to transpiration rates in order to avoid possible measurement errors as a consequence of low turbulent conditions during nighttime hours.

To estimate the contribution of stand transpiration to total evapotranspiration, we confronted sap flux derived transpiration rates with eddy covariance derived evapotranspiration rates. As described in Niu et al. (2015), our methodological approach for estimating sap flux is associated with sample size related measurement errors of about $14 \%$. The eddy covariance measurements were carried out in carefully-chosen and well-suited locations and focused on daytime observations only, when estimation uncertainties are commonly low (<30\%, Richardson et al., 2006). The observed differences between evapotranspiration and transpiration estimates presented in this study are thus likely largely due to natural rather than methodological reasons. 


\subsubsection{Environmental drivers of oil palm water use}

A total of three micrometeorological stations were set up in proximity to the oil palm stands in both landscapes; for the analysis of the water use characteristics of the respective stands, we used the micrometeorological data from the closest available station, at a maximum distance of approx. $15 \mathrm{~km}$ and at similar altitude (60 $\mathrm{m} \pm 15 \mathrm{~m}$ a.s.l.). The stations were placed in open terrains. Air temperature and relative humidity were measured at a height of $2 \mathrm{~m}$ with a Thermohygrometer (type 1.1025.55.000, Thies Clima, Göttingen, Germany) to calculate vapor pressure deficit (VPD, kPa). A short wave radiation sensor (CMP3 Pyranometer, spectral range 300-2800 nm, Kipp \& Zonen, Delf, The Netherlands) was installed at a height of $3 \mathrm{~m}$, the latter to measure global radiation $\left(R_{\mathrm{g}}, \mathrm{MJ} \mathrm{m}^{-2}\right.$ $\mathrm{d}^{-1}$, from here on referred to as "radiation"). Measurements were taken every $15 \mathrm{sec}$ and averaged and stored on a DL16 Pro data logger (Thies Clima) every $10 \mathrm{~min}$.

The eddy covariance towers (see eddy covariance measurements and evapotranspiration) were also equipped with micrometeorological sensors. Measurements were taken above the canopy, at respective heights of 6.7 and $22 \mathrm{~m}$. Air temperature and humidity (Thermohygrometer, type 1.1025.55.000, Thies Clima), short wave radiation (BF5, Delta-T, Cambridge, United Kingdom) and net radiation (CNR4 Net radiometer, Kipp \& Zonen) were measured every $15 \mathrm{sec}$ and averaged and stored on a DL16 Pro data logger (Thies Clima) every 10 min.

Soil moisture was recorded in the center of eight of the 15 study plots and at the micrometeorological stations and eddy covariance towers. Soil moisture sensors (Trime-Pico 32, IMKO, Ettlingen, Germany) were placed $0.3 \mathrm{~m}$ under the soil surface and connected to a data logger (LogTrans16GPRS, UIT, Dresden, Germany). Data were recorded every hour, for 16 months from June 2013 on. Exploratory analyses showed no significant effects of soil moisture on water use rates $(P>0.1)$. Soil moisture fluctuated only little at the respective locations and during the respective measurement periods and even on a yearly scale, e.g. between $32 \pm 2 \%$ and $38 \pm 2 \%$ between June 2013 and June 2014 (minimum and maximum daily values, mean \pm SE between the three micrometeorological stations). Soil moisture did e.g. also not fall below 36\% during the measurement period in the longterm monitoring (BO3) stand. It was non-limiting for plant water use. As it showed no significant relationship with water use rates, we omitted soil moisture from further analyses of influences of fluctuations in environmental variables on oil palm water use. Likewise, further recorded micrometeorological variables (e.g. air pressure, wind speed) had no significant relationship with water use rates in our study and where thus also omitted. We instead focused on the micrometeorological drivers VPD and global radiation; among an array of micrometeorological variables (e.g. also including temperature, humidity, net radiation) exploratory analysis had shown that they were best suited to explain fluctuations in water use rates. This has also been demonstrated 
in other studies on plant water use (e.g. Dierick and Hölscher, 2009; Köhler et al., 2009, 2013) For the diurnal analysis, we averaged the values of three comparably sunny days and normalized VPD and radiation by setting the highest observed hourly rates to one.

All statistical analyses and graphing were performed with R version 3.1.1 (R Core Development team, 2014) and Origin 8.5 (Origin Lab, Northampton, MA, USA).

\subsection{Results}

\subsubsection{Stand characteristics}

The number of palms per unit of land linearly decreased with increasing stand age $\left(R^{2}=0.29, P=\right.$ 0.04; Figure 4.2a). The number of leaves per palm remained constant and varied little (32-40 leaves per palm) over stand age (Figure 4.2b). The trunk height of oil palms (Figure 4.2c) increased linearly with increasing age $\left(R^{2}=0.91, P<0.01\right)$, from about $2 \mathrm{~m}$ at an age of six to about $9 \mathrm{~m}$ at an age of 25 years. The average baseline length of leaf petioles at the location of sensor installation increased linearly with stand age $\left(R^{2}=0.65, P<0.01\right)$. As the number of leaves was constant in mature stands, the increasing baseline lengths of leaf petioles resulted in a significant linear increase of the water conductive area per palm with increasing stand age $\left(R^{2}=0.53, P<0.01\right)$. In consequence, the standlevel water conductive area also linearly increased with stand age $\left(R^{2}=0.26, P=0.05\right.$; Figure 4.2d). 

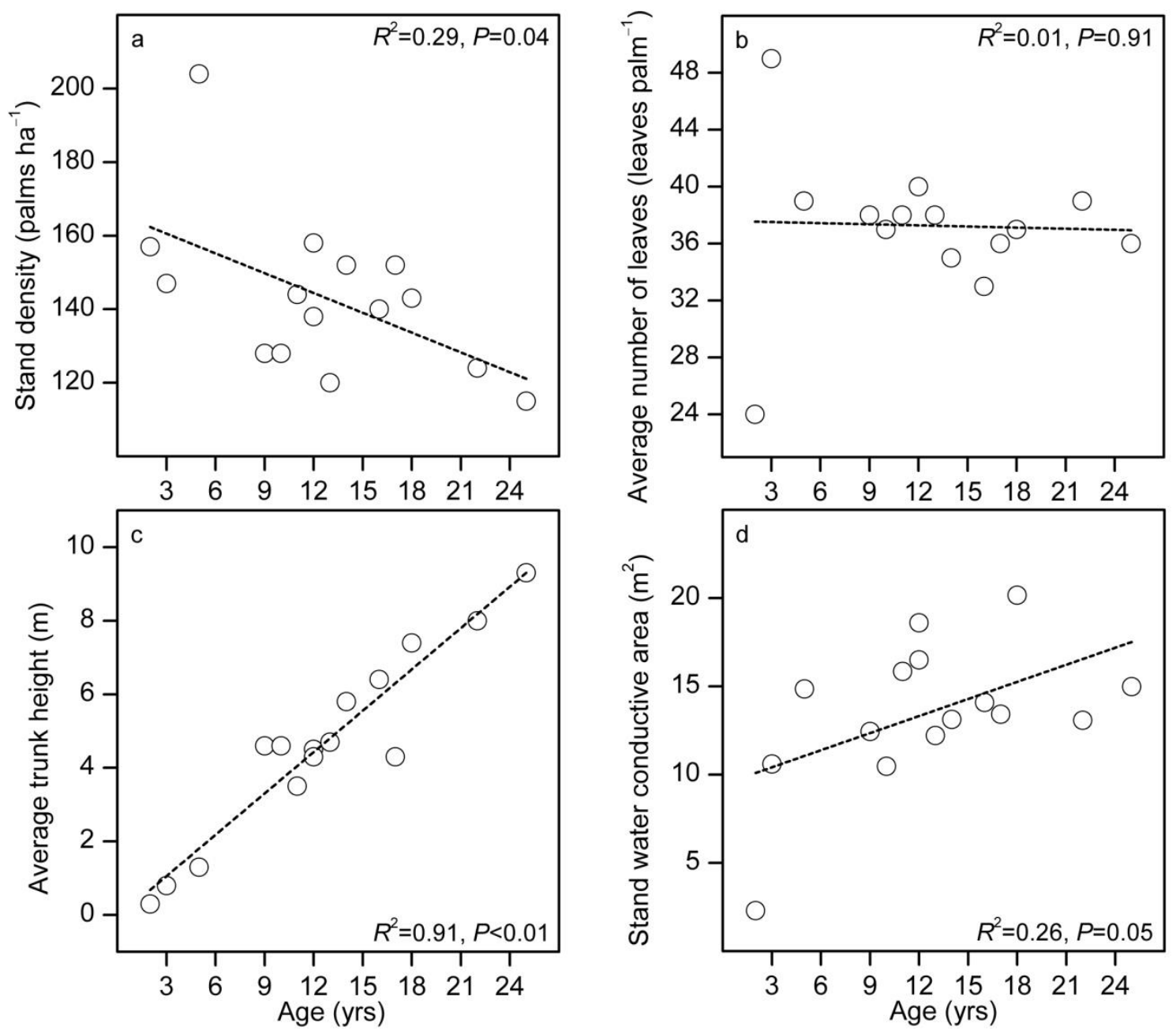

Figure 4.2 The change of stand density (a), average number of leaves per palm (b), average trunk height (c), and stand water conductive area (d) over age in the 15 studied oil palm stands.

\subsubsection{Transpiration and evapotranspiration}

Maximum sap flux densities on three sunny days as measured in the leaf petioles of oil palms were variable but did not show a significant trend over age among the examined stands (Figure 4.3a). Converted to leaf water use, a clear non-linear trend over stand age became apparent $\left(R^{2}\right.$ adj $=0.61, P$ $<0.01$ for the Hill function, see Morgan et al., 1975, fit shown in Appendix Figure 4.1b, not shown in Figure 4.3b): Leaf water use increased 5-fold from a 2-yr-old stand to a plot age of about 10 years; it then remained relatively constant with further increasing age. At the palm level (Figure 4.3c), water use rates closely resemble the relationship of leaf water use and stand age. At the stand level, oil palm transpiration was very low $\left(0.2 \mathrm{~mm} \mathrm{~d}^{-1}\right)$ in the 2-year old stand and increased almost 8-fold until a stand age of 5 years. It then remained relatively constant with increasing age at around $1.3 \mathrm{~mm} \mathrm{~d}^{-1}$ (Figure 4.3d). However, three medium-aged stands (PTPN6, BO5, and HO2) that showed increased sap flux densities and leaf and palm water use rates also had higher stand transpiration rates, between 2.0 and $2.5 \mathrm{~mm} \mathrm{~d}^{-1}$. Potentially, this could be related to differences in radiation on the respective three 
sunny days that were chosen for the analysis. However, there was no significant relationship between average water use rates on the respective three sunny days in the 15 stands and the respective average radiation (or VPD) on those days (linear regression, $P>0.05$ ), i.e. observed spatial variability in transpiration among the 15 stands could not be explained by differences in weather conditions. A further analysis of the water use rates of eight medium-aged stands with highly variable transpiration rates also gave no indications of variability being induced by differences in radiation. As for the leafand palm-level water use rates, a Hill function explained the relationship between stand transpiration and stand age $\left(R^{2}\right.$ adj $\left.=0.45, P<0.01\right)$, but the observed scatter was high, particularly among medium aged plantations. Overall, stand transpiration rates increased linearly with increasing stand water conductive area $\left(R^{2}=0.42, P=0.01\right)$. On the palm level, there was a linear relationship between water use and trunk height $\left(R^{2}=0.32, P=0.03\right)$, but stand transpiration did not have a linear relationship with average stand trunk height due to decreasing stand densities with increasing stand age; instead, as for transpirations vs. stand age, a Hill function explained the relationship between transpiration and stand trunk height best $\left(R^{2}\right.$ adj $\left.=0.44, P<0.01\right)$ (also see summary in Table 4.2).

On comparably sunny days, the stand-level transpiration among the 15 oil palm stands varied 12 -fold, from $0.2 \mathrm{~mm} \mathrm{~d}^{-1}$ in a 2-year old to $2.5 \mathrm{~mm} \mathrm{~d}^{-1}$ in a 12-year old stand. A large part of this spatial variability was explained by different stand variables when applying the Hill function. Stand age explained $45 \%$ of the observed spatial variability of stand transpiration (i.e. $R^{2}$ adj $=0.45$ at $P<0.01$, Figure $4.3 \mathrm{~d}$ ), and variables correlated to stand age, i.e. by average stand trunk height and by stand water conductive area, explained $44 \%$ and $43 \%$, respectively. Much of the remaining variability in stand transpiration rates could be explained by varying stand densities (variations of up to $30 \%$ between stands of similar age, see Table 4.1). Thus, when shifting from the stand level to the palm level, up to $60 \%$ of the spatial variability in palm water use rates could be explained by age and correlated variables (see Figure $4.3 \mathrm{c}$ and Table 4.2). Much of the variability that remains on the palm level is induced by three stands where palm water use was much higher $\left(>150 \mathrm{~kg} \mathrm{~d}^{-1}\right)$ than in the other 12 stands $\left(<125 \mathrm{~kg} \mathrm{~d}^{-1}\right)$; excluding these three stands from the analysis, $87 \%$ of the spatial variability in palm water use rates could be explained by age (Table 4.3).

Evapotranspiration rates derived from the eddy covariance technique for the 2-yr-old stand (PA) were $2.8 \mathrm{~mm} \mathrm{~d}^{-1}$ (average of three sunny days); the contribution of sap flux derived transpiration was $8 \%$. For the 12-year old stand (PTPN6), the evapotranspiration estimate was $4.7 \mathrm{~mm} \mathrm{~d}^{-1}$; transpiration amounted to about $53 \%$. 

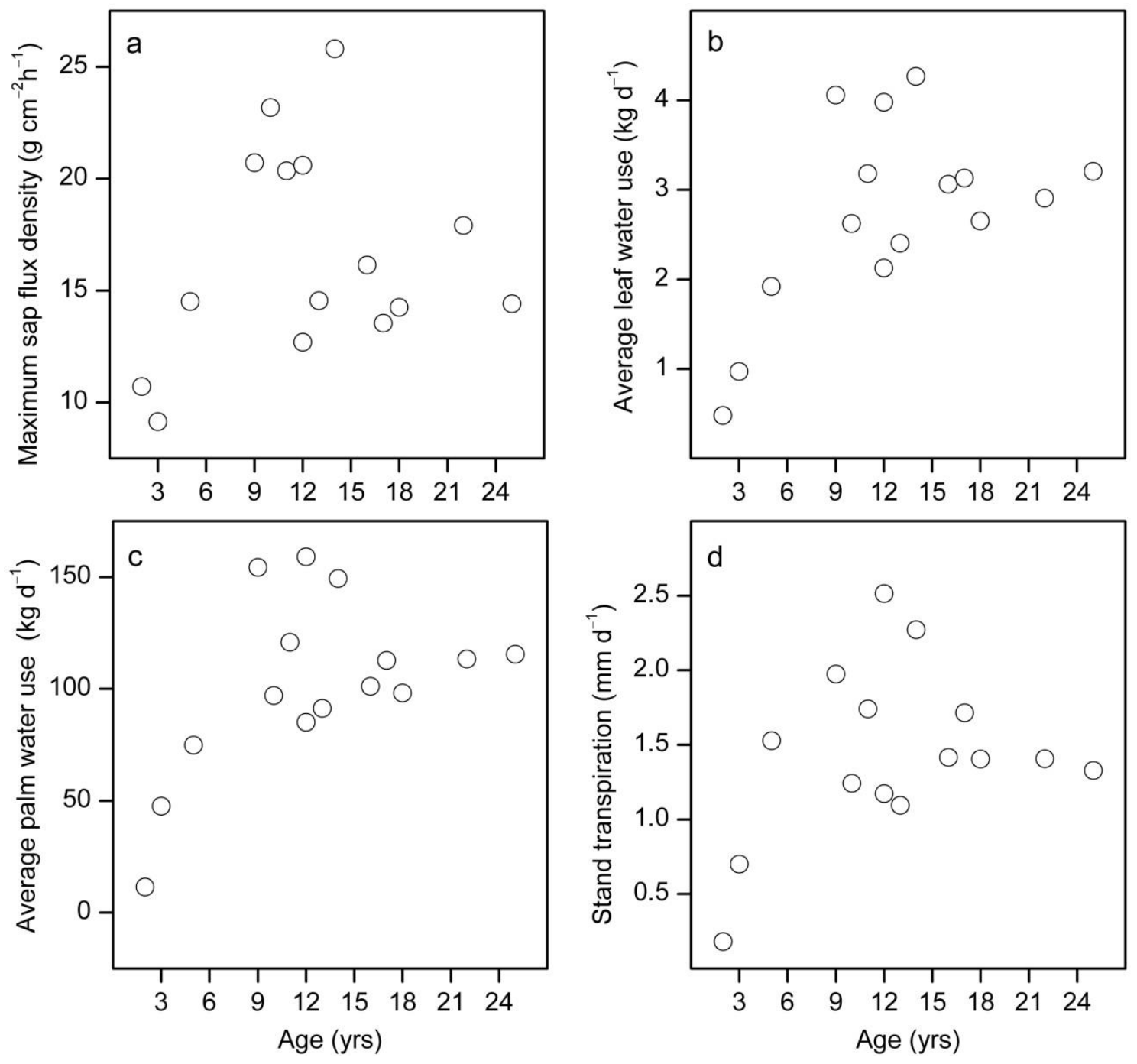

Figure 4.3 The change of maximum hourly sap flux density (a), average leaf water use (b), average palm water use (c) and stand transpiration (d) over stand age. Data of the different levels derived from simultaneous sap flux measurements on at least 13 leaves per stand; values of three sunny days averaged.

\subsubsection{Drivers of oil palm water use}

Radiation peaked between 12 am and $1 \mathrm{pm}$ while vapor pressure deficit peaked at around $3 \mathrm{pm}$; the diurnal course of sap flux densities on three sunny days except for the 2-yr-old stand (PA) showed an early peak of sap flux density (10 to $11 \mathrm{am}$ ), which then decreased throughout the rest of the day (Figure $4.4 \mathrm{a}$ and $4.4 \mathrm{~b}$, respectively).Thus, there was a varying and partly pronounced hysteresis in the leaf-level response of transpiration to VPD (Figure 4.4c). It was small in the 2-year old stand (PA). In contrast, it was very pronounced in the 12-year old PTPN6 stand (high water use, commercial plantation), where a very sensitive increase of water use rates with increasing VPD during the morning hours was observed, reaching a peak in water use rates at only about $60 \%$ of maximum daily 
VPD. After that, water use rates declined relatively consistently throughout the day, despite further rises in VPD. The same pattern was observed in most of the stands; we present values for the oldest stand (HAR_old, 25 years) and another 12-year old stand (BO3, low water use, small-holder plantation) as further examples. The hysteresis in the transpiration response to radiation (Figure $4.4 \mathrm{~d}$ ) was generally less pronounced than for VPD.

The day-to-day behavior of oil palm leaf water use rates to environmental drivers (i.e. VPD, radiation) seemed "buffered", i.e. already relatively low VPD and radiation lead to relatively high water use rates (except for in the 2-yr-old stand), while even strong increases in VPD and radiation only induced rather small further increases in water use rates (Figure 4.5). For the 2-year-old stand (PA), leaf water use rates over time were almost constant (about $0.4 \mathrm{~kg} \mathrm{~d}^{-1}$ ), regardless of daily environmental conditions. Likewise, the water use rates of the remaining stands were relatively insensitive to increases in VPD, i.e. two-fold increases in VPD only led to 1.1- to 1.2-fold increases in water use rates (Figure 4.5). A similarly buffered water use response to radiation was observed for the 12-year old small-holder stand (BO3) and the 25-year old stand (HAR_old), i.e. 1.5- and 1.3-fold increases, respectively, for two-fold increases in radiation. The water use response to fluctuations in radiation of the 12-year old commercial stand (PTPN6) was more sensitive, i.e. two-fold increases in radiation induced 1.8-fold increases in water use rates (Figure 4.5). The PTPN6 stand also had the highest absolute water use rates among the studied stands. 

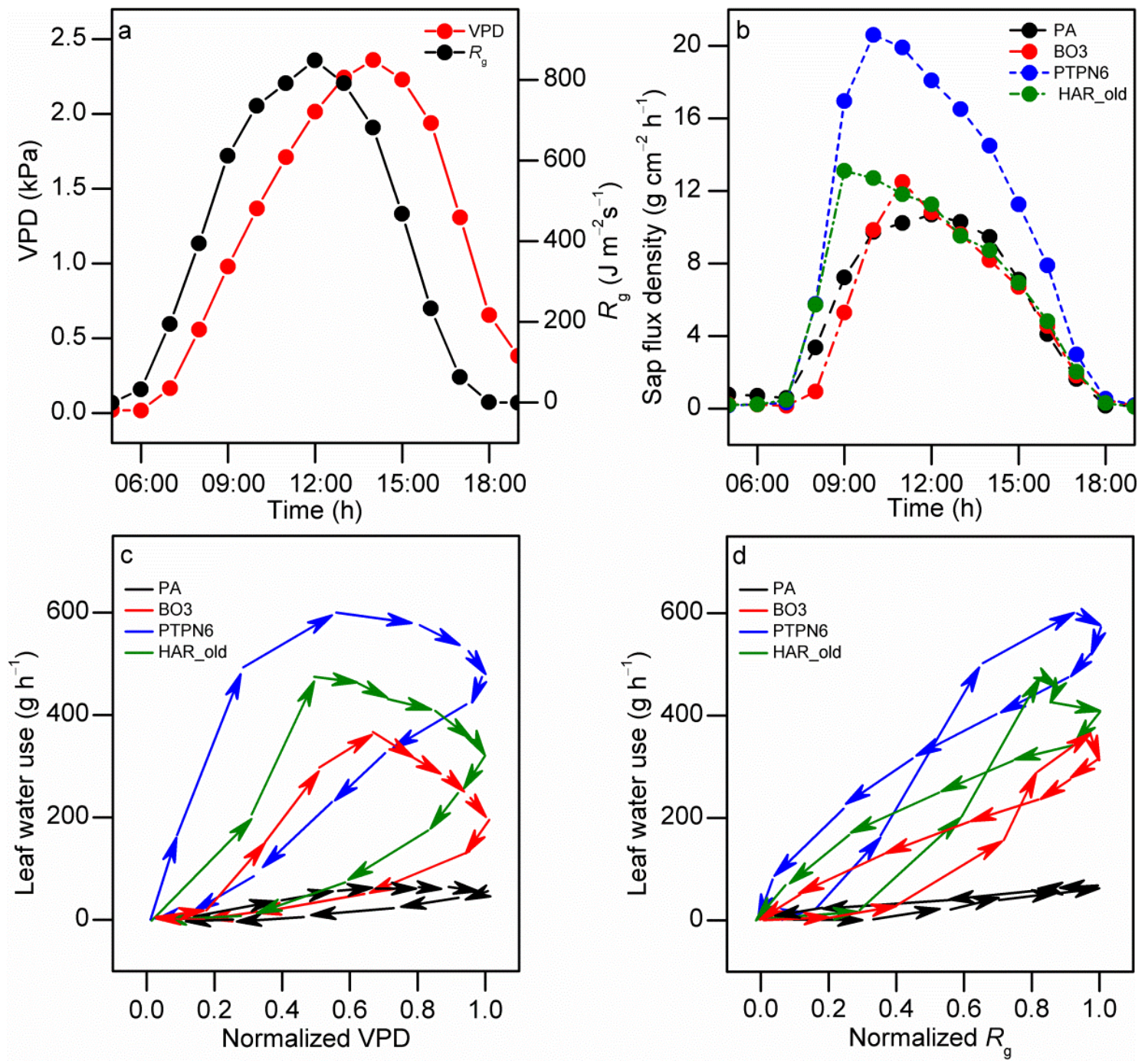

Figure 4.4 Diurnal course of vapor pressure deficit (VPD) and radiation $\left(R_{\mathrm{g}}\right)$ (a) and of sap flux density in four oil palm stands (b). Leaf water use plotted against hourly averages of normalized VPD (c) and $R_{\mathrm{g}}(\mathrm{d})$. Average water use estimates based on at least 13 leaves measured simultaneously; average water use rates, VPD and radiation of three sunny days, each point represents one hourly observation. Data are from the locations PA (2 years old, black arrows), BO3 (12 years old, low water use, red arrows), PTPN6 (12 years old, high water use, blue arrows) and HAR_old (25 years old, green arrows). Data were normalized by setting the maximum to one. 

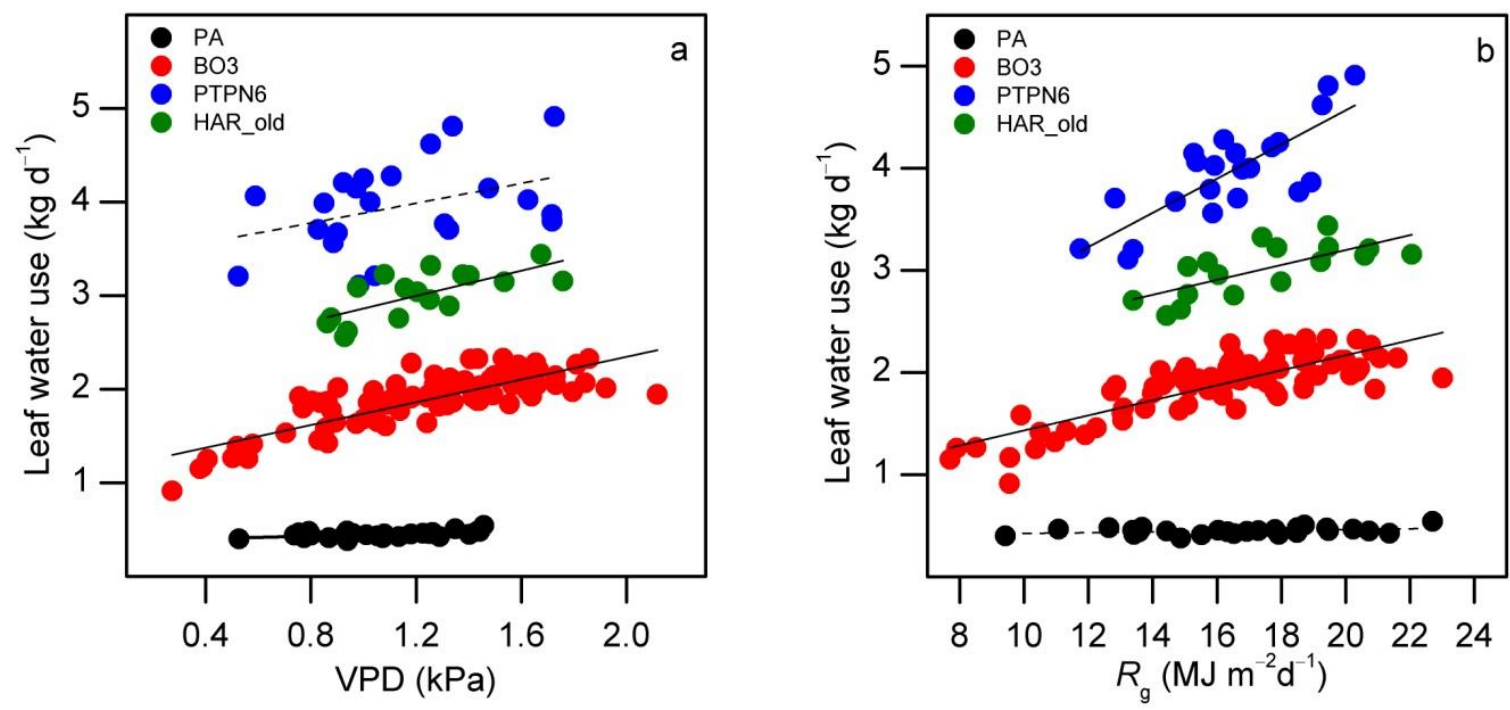

Figure 4.5 The day-to-day response of leaf water use rates in four different oil palm stands to changes in average daytime vapor pressure deficit (VPD) (a) and integrated daily radiation $\left(R_{\mathrm{g}}\right)$ (b) taken from the closest micrometeorological station from the respective plots. Data of at least 20 days per plot, each point represents one day. Leaf water use rates are from the locations PA (2 years old, black circles), BO3 (12 years old, low water use, red circles), PTPN6 (12 years old, high water use, blue circles) and HAR_old (25 years old, green circles). Significant linear relationships are indicated with solid $(P<0.05)$ and dotted $(P<0.1)$ lines, regression functions are provided in the figure. 

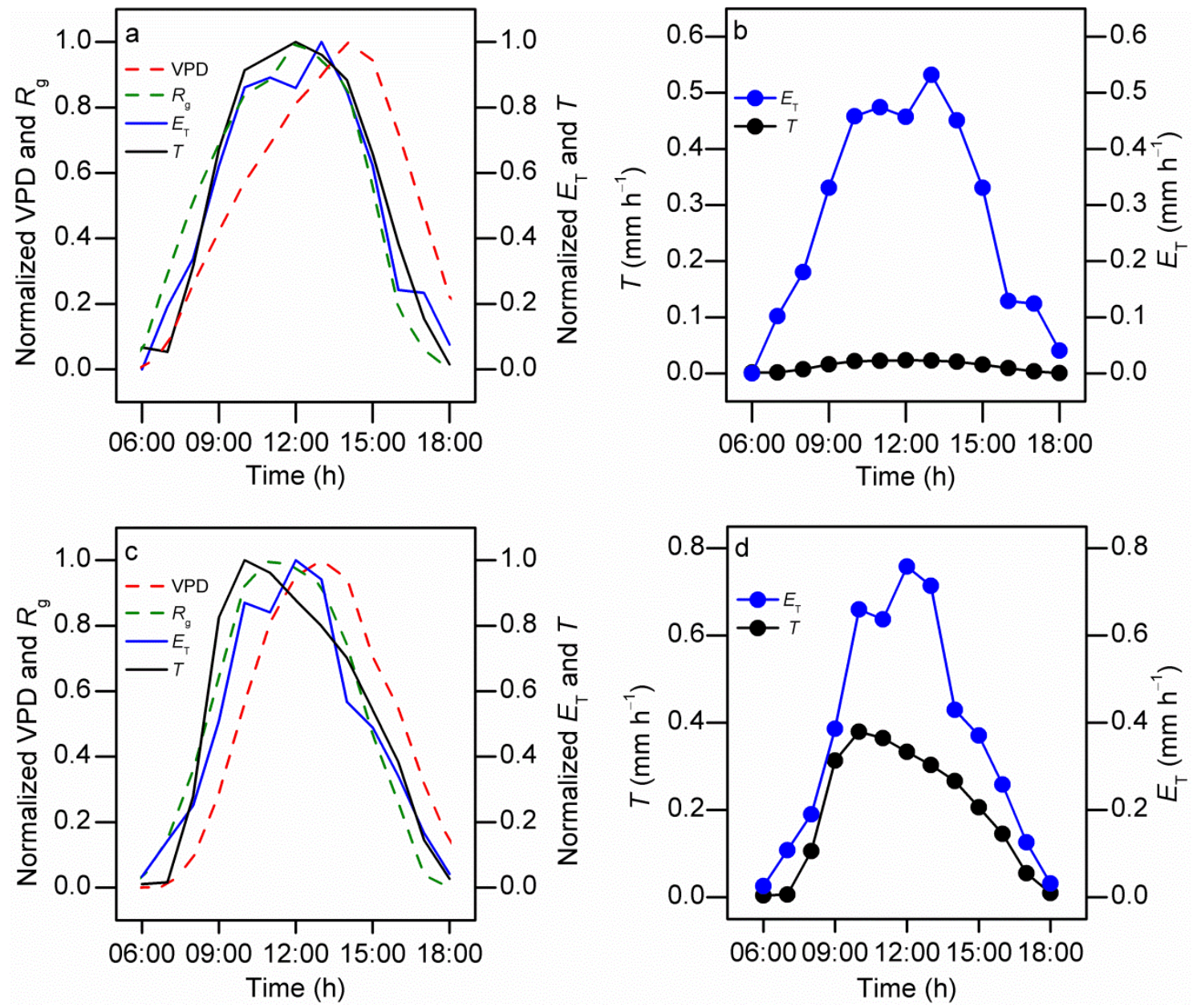

Figure 4.6 Normalized diurnal pattern of vapor pressure deficit (VPD), radiation $\left(R_{\mathrm{g}}\right)$, transpiration $(T)$ and evapotranspiration $\left(E_{\mathrm{T}}\right)$ in a 2-year-old (PA) (a) and a 12-year-old (PTPN6) (c) oil palm stand; absolute hourly values of $E_{\mathrm{T}}$ and $T$ in PA (b) and PTPN6 (d). Eddy covariance and sap flux density measurements were conducted in parallel to derive evapotranspiration and transpiration rates, respectively. Values of three sunny days averaged. 


\subsection{Discussion}

\subsubsection{Oil palm transpiration over age}

Among 13 studied productive oil palm stands (i.e. $>4$ years old) stand transpiration rates varied more than two-fold. The observed range (1.1-2.5 $\mathrm{mm} \mathrm{d}^{-1}$ ) compares to transpiration rates derived with similar techniques in a variety of tree-based tropical land-use systems, e.g. an Acacia mangium plantation on Borneo (2.3 $\mathrm{mm} \mathrm{d}^{-1}$ for stands of relatively low density, Cienciala et al., 2000), cacao monocultures and agroforests with varying shade tree cover on Sulawesi $\left(0.5-2.2 \mathrm{~mm} \mathrm{~d}^{-1}\right.$, Köhler et al., 2009, 2013) and reforestation and agroforestry stands on the Philippines and in Panama (0.6-2.5 $\mathrm{mm} \mathrm{d}^{-1}$, Dierick and Hölscher, 2009; Dierick et al., 2010). The highest observed values for oil palm stands (2.0-2.5 $\mathrm{mm} \mathrm{d}^{-1}$, PTPN6, BO5, and HO2 stands) compare to or even exceed values reported for tropical forests (1.3-2.6 $\mathrm{mm} \mathrm{d}^{-1}$; Calder et al., 1986; Becker, 1996; McJannet et al., 2007), suggesting that oil palms can transpire at substantial rates under certain, yet unexplained site or management conditions despite e.g. a much lower biomass per hectare than in natural forests (Kotowska et al., 2015).

In the 15 studied oil palm stands, stand-level transpiration rates increased almost 8-fold from an age of two years to a stand age of five years; they then remained relatively constant with further increasing age but were highly variable among productive stands. In our study region, oil palm plantations are commonly cleared and replaced at an age of max. 25-30 years due to constrictions in fruit harvest with further increasing palm height; the oldest studied stand was 25 years old. In contrast to previous studies for dicot tree mono-cultural stands of varying age we thus did not find, after a relatively early peak, lower stand transpiration rates with increasing stand age (e.g. Jayasuriya et al., 1993; Roberts et al., 2001; Vertessy et al., 2001; Delzon and Loustau, 2005). Asides from the productivity-related artificial short oil palm lifespan in our studied stands as opposed to much larger time-scales in studies on tree stands (e.g. comparison of 10- and 91-year old stands in Delzon and Loustau, 2005), this is also related to differences in stand establishment: oil palms are commonly planted in a fixed, relatively large grid, which results in a less pronounced reduction of stand density with increasing stand age than in dicot tree stands, which are often established at much higher stand densities and consequently show higher density-dependent mortality rates. After an initial steep rise of transpiration at a very young plantation age, stand transpiration thus does not seem to vary considerably over the life span of a certain oil palm plantation, which contrasts with the water use characteristics of tree plantations.

The observed substantial stand-to-stand variability of transpiration among the 15 stands, particularly among medium aged plantations, could to $60 \%$ be explained by the variables stand age and density, 
and up to $87 \%$ when excluding three stands with much higher water use. The remaining unexplained variability as well as the high water use rates in the three mentioned stands could be related to differences in site and soil characteristics. However, all studied stands were located in comparable landscape positions (i.e. upland sites of little or medium inclination) and on similar mineral soils, i.e. loam or clay Acrisols of generally comparable characteristics (Allen et al., 2015; Guillaume et al., 2015). Differences in management intensity could also contribute to the remaining unexplained variability of stand transpiration rates over age. E.g., on P-deficient soils such as the Acrisols of our study region (Allen et al., 2015), fertilization can greatly increase oil palm yield (Breure, 1982) and thus total primary productivity, which could consequently lead to a higher water use of oil palms. Accordingly, the highest observed transpiration value in our study came from a stand in an intensively and regularly fertilized, high yielding commercial plantation. Thus, there may be a trade-off between management intensity, and hence yield, on the one hand, and water use of oil palms on the other hand. This trade-off is of particular interest in the light of the continuing expansion of oil palm plantations (FAO, 2014) and increasing reports of water scarcity in oil palm dominated areas (Obidzinski et al., 2012; Larsen et al., 2014).

\subsubsection{Evapotranspiration and the contribution of transpiration}

Our eddy-covariance derived evapotranspiration estimates of 2.8 and $4.7 \mathrm{~mm} \mathrm{~d}^{-1}$ (on sunny days, in 2and 12-year old stands, respectively) compare very well to the range reported for oil palms in other studies: For 3-4 year old stands in Malaysia, eddy-covariance derived values of $1.3 \mathrm{~mm} \mathrm{~d}^{-1}$ and 3.3-3.6 $\mathrm{mm} \mathrm{d}^{-1}$ were reported for the dry and rainy season, respectively (Henson and Harun, 2005). For mature stands, a value of $3.8 \mathrm{~mm} \mathrm{~d}^{-1}$ was given, derived by the same technique (Henson, 1999). Micrometerologically-derived values for 4-5 year old stands in Peninsular India were $2.0-5.5 \mathrm{~mm} \mathrm{~d}^{-1}$ during the dry season (Kallarackal et al., 2004). A catchment-based approach suggested values of 3.3-3.6 $\mathrm{mm} \mathrm{d}^{-1}$ for stands in Malaysia between 2 and 9 years old (Yusop et al., 2008); evapotranspiration rates derived from the Penman-Monteith equation and published data for various stands were $1.3-2.5 \mathrm{~mm} \mathrm{~d}^{-1}$ in the dry season and 3.3-6.5 $\mathrm{mm} \mathrm{d}^{-1}$ in the rainy season (Radersma and Ridder, 1996). The values reported in most available studies as well as our values overlap in a corridor from about $3 \mathrm{~mm} \mathrm{~d}^{-1}$ to about $5 \mathrm{~mm} \mathrm{~d}^{-1}$; this range compares to evapotranspiration rates reported for rainforests in South East Asia (e.g. Tani et al., 2003a; Kumagai et al., 2005). Considering that oil palm stands e.g. have much lower stand densities and biomass per hectare than natural tropical forests (Kotowska et al., 2015), this indicates a quite high evapotranspiration from oil palms at both the individual and the stand level. Additionally to the previously discussed relatively high water use of oil palms under certain site or management conditions, the high evapotranspiration from oil palm can be explained by substantial additional water fluxes to the atmosphere. These fluxes (i.e. the 
differences between evapotranspiration and transpiration estimates) were substantial in both the 2year old and the 12-year old oil palm stand, i.e. 2.6 and $2.2 \mathrm{~mm} \mathrm{~d}^{-1}$, respectively. In the 2-year old PA stand the contribution of palm transpiration to total evapotranspiration was very low (8\%, Figure 4.6).The majority of water fluxes to the atmosphere came from evaporation (e.g. from the soil, interception) and transpiration by other plants. The spaces between palms (planting distance approx. 8 $\times 8 \mathrm{~m}$ ) were covered by a dense, up to $50 \mathrm{~cm}$ high grass layer at the time of study (approx. 60\% ground cover); transpiration rates from grasslands can exceed those of forests (e.g. review in McNaughton and Jarvis, 1983; Kelliher et al., 1992) and could well account for 1-2 $\mathrm{mm} \mathrm{d}^{-1}$ to (partly) explain the observed difference of $2.6 \mathrm{~mm} \mathrm{~d}^{-1}$ between evapotranspiration and transpiration estimates in the PA stand. The 2-year old oil palms were still very small (average trunk height $0.3 \mathrm{~m}$, overall height $1.8 \mathrm{~m}$ ) and had a low average number of leaves, 24 as opposed to $37 \pm 1$ (mean $\pm \mathrm{SD}$ ) between the 15 studied stands; further, leaves were much smaller than in mature stands. Leaf area index (LAI) of 2-year old oil palm stands was reported be at least 5-fold lower (LAI < 1) than in mature stands of similar planting density as our study plots (Henson and Dolmat, 2003). The very low observed water use of the oil palms in PA $\left(12 \mathrm{~kg} \mathrm{~d}^{-1}\right.$ per palm compared to approx. $100 \mathrm{~kg} \mathrm{~d}^{-1}$ per palm in mature stands) and the consequent very low contribution of palm transpiration to evapotranspiration thus do not seem contradictory. At PTPN6 (12 years old) transpiration rates as well as the contribution of transpiration to evapotranspiration (53\%) were much higher than in the 2-year old stand (PA); also, total evapotranspiration was almost 70\% higher. The sum of evaporation (e.g. from the soil) and transpiration by other plants was of similar magnitude $\left(2.2 \mathrm{~mm} \mathrm{~d}^{-1}\right.$, i.e. $15 \%$ lower) as in PA. Due to the intense management, there was very little ground vegetation in inter-rows present in the PTPN6 stand. However, the abundant trunk epiphytes in butts of pruned leaf petioles that remain on the trunks of mature oil palms may contribute significantly to non-palm transpirational water fluxes. Additionally, oil palm trunks were reported to have a large potential external water storage capacity (up to $6 \mathrm{~mm}$, Merten et al., 2016) for stemflow water after precipitation events; the mentioned butts of pruned leaf petioles constitute "chambers" filled with humus, water and epiphytes, which can remain moist for several days following rainfall events. On dry, sunny days of high evaporative demand, the (partial) drying out of these micro-reservoirs may significantly contribute to water fluxes from evaporation. This is supported by the diurnal course of all water fluxes except oil palm transpiration at PTPN6 (calculated by subtracting hourly transpiration from evapotranspiration rates), which closely followed VPD until its $3 \mathrm{pm}$ peak, but then declined rapidly. Generally, our comparison of eddy-covariance derived evapotranspiration and sap-flux derived transpiration suggests significant other water fluxes to the atmosphere than transpiration (e.g. from evaporation) that are still marginal during the morning hours, reach their peak at the time VPD peaks and are extremely sensitive to decreasing VPD in the afternoon. In our study, transpiration amounted to only $8 \%$ and $53 \%$ of evapotranspiration in the two year-old and the 12 year-old oil palm stand, respectively, which 
is lower than values reported e.g. for mature coconut stands (68\%, Roupsard et al., 2006) and rainforests in Malaysia (81-86\%, Tani et al., 2003b). The low relative contribution of palm transpiration to total evapotranspiration in oil palm stands could be due to relatively high water fluxes from evaporation, e.g. after rainfall interception. Interception was reported to be substantially higher in oil palm stands in the study region (28\%, Merten et al., 2016) than e.g. in rainforests in Malaysia (12-16\%, Tani et al., 2003b) and Borneo (18\%, Dykes, 1997). The high water losses from interception paired with the relatively high water use of oil palms and the consequent high total evapotranspirational fluxes from oil palm plantations could contribute to reduced water availability at the landscape level in oil palm dominated areas, e.g. during pronounced dry periods (Merten et al., 2016).

\subsubsection{Micrometeorological drivers of oil palm water use}

At the diurnal scale, we examined the relationship between water use rates and VPD and radiation (hourly averages of three sunny days, Figure 4.4): In all examined oil palm stands except the very young stand (PA, 2 years old), under comparable sunny conditions, the intra-daily transpiration response to the mentioned environmental drivers was characterized by an early peak (10 am-11 am), before radiation (12 am-1 pm) and VPD (2 pm-3 pm) peaked; after this early peak of water use rates, however, they subsequently declined consistently throughout the day, regardless of further increases of radiation and VPD (Figure 4.4). For most thus far examined dicot tree species, peaks in water use rates coincide with peaks in radiation (e.g. Zeppel et al., 2004; Köhler et al., 2009; Dierick et al., 2010; Horna et al., 2011); however, a similar behavior as in oil palms, i.e. early peaks of transpiration followed by consistent declines, has been reported, but not yet explained, for Acer rubrum L. (Johnson et al., 2011) and some tropical bamboo species (Mei et al., 2015). Due to the early peaks, considerable hysteresis in the oil palm transpiration response to VPD was observed in all examined stands except for PA (2 years old). In studies on tree species, pronounced hysteresis has been reported e.g. for eucalyptus trees in Australia during the dry season (O'Grady et al., 1999; Zeppel et al., 2004) or for popular hybrids on clear, but not on cloudy days (Meinzer et al., 1997). The underlying ecohydrological mechanisms remain yet unexplained; potentially, the development of water stress (Kelliher et al., 1992), decreasing leaf stomatal conductance and assimilation rates over the course of a day (Eamus and Cole, 1997; Williams et al., 1998; Zeppel et al., 2004) or changes in leaf water potential, soil moisture content or xylem sap abscistic acid content (Prior et al., 1997; Thomas et al., 2000; Thomas and Eamus, 2002) could play a role. For oil palms, no eco-physiological studies are available yet to assess these potential underlying reasons for the observed pronounced diurnal transpirational hysteresis. A contribution of stem water storage to transpiration in the morning could be another potential explanation (Waring and Running, 1978; Waring et al., 1979, Goldstein et al., 
1998). It could explain the early peak followed by a steady decline of transpiration regardless of VPD and radiation patterns, the decline being the consequence of eventually depleted trunk water storage reservoirs. Other (palm) species were reported to have substantial internal trunk water storage capacities (e.g. Holbrook and Sinclair, 1992; Madurapperuma et al., 2009), which can contribute to sustain relatively high transpiration rates despite limiting environmental conditions (e.g. Vanclay, 2009).

At the day-to-day scale, in all 15 oil palm stands, the response of water use rates particlularly to changes in VPD seemed "buffered", i.e. near-maximum daily water use rates were reached at relatively low VPD, but better environmental conditions for transpiration (i.e. higher VPD) did not induce strong increases in water use rates (i.e. 1.2-fold increase in water use for a two-fold increase in VPD). Likewise, for both photosynthesis rates (Dufrene and Saugier, 1993) and water use rates (Niu et al., 2015) of oil palm leaves, linear increases with increasing VPD were reported at relatively low VPD, until a certain threshold $(1.5-1.8 \mathrm{kPa})$ was reached, after which no further increases in photosynthesis and water use rates, respectively, occurred. For tropical tree and bamboo species, more sensitive responses to fluctuations in VPD, i.e. 1.4- to 1.7-fold increases and more than two-fold increases, respectively, have been reported (e.g. Köhler et al., 2009; Dierick et al., 2010, Komatsu et al., 2010). However, a similar "levelling-off" effect of water use rates at higher VPD, as observed for the oil palm stands in our study, has been reported for Moso bamboo stands in Japan (in contrast to coniferous forests in the same region, where water use had a linear relationship with VPD, Komatsu et al., 2010). The hydraulic limitations "buffering" the day-to-day oil palm water use response to VPD are yet to be explained. As soil moisture was non-limiting, they are likely of micrometeorological or eco-physiological nature. The early peaks of water use rates and the consequent strong hysteresis to VPD on the intra-daily level, which may point to a depletion of internal trunk water storage reservoirs early in the day as a possible reason for substantially reduced oil palm water use rates at the time of diurnally optimal environmental conditions, give some first indications of the direction that further studies could take.

\subsection{Conclusions}

The study provides first insights into eco-hydrological characteristics of oil palms at varying spatial and temporal scales and first estimates of oil palm stand transpiration rates across an age gradient. Stand transpiration rates increased almost 8 -fold from an age of two years to a stand age of five years and then remained constant with further increasing age, but were highly variable among medium-aged plantations. In some of the studied stands, transpiration was quite high, i.e. higher than values reported for tropical rainforests. There may be a potential trade-off between water use and management intensity of oil palm plantations. Total evapotranspirational water fluxes from a two and 
a 12 year-old oil palm plantation were also relatively high, i.e. other water fluxes besides transpiration (e.g. from the soil) contributed substantially and variably to evapotranspiration. This reduced a 12fold difference in transpiration between the two stands to a less than two-fold difference in evapotranspiration. In the diurnal course, most oil palms showed a strong hysteresis between water use and VPD. On the day-to-day basis this results in a relatively low variability of oil palm water use regardless of fluctuations in VPD and radiation. In conclusion, oil palm dominated landscapes show some spatial variations in (evapo)transpiration rates, e.g. due to varying age-structures and stand densities, but the day-to-day variability of oil palm transpiration is rather low. Under certain site or management conditions, (evapo)trans-pirational water fluxes from oil palms can be substantial.

\section{Data availability}

The underlying data of this manuscript is deposited and stored in the EFForTS-IS data base (https://efforts-is.uni-goettingen.de) of the CRC990 of the Georg-August-Universität Göttingen, Germany (www.uni-goettingen.de/crc990). Due to project data sharing agreement limitations, this data base is not publicly accessible, and digital identifiers and citations can thus not be provided. However, the data are stored safely and according to the good practise of data storage as e.g. demanded by the DFG (German Research Foundation). To make the underlying data of our manuscript accessible for readers, we have attached them as a zipped supplement to this manuscript. Inside this supplement, all data used in this manuscript can be found in the form of 30-min observations for each respective stand.

\section{Acknowledgements}

This study was supported by a grant from the German Research Foundation (DFG, CRC 990, A02, A03). Furong Niu received a scholarship from the China Scholarship Council (CSC); Afik Hardanto received a scholarship from the Indonesian-German Scholarship Program (IGSP). The authors thank Pak Heri Junedi and Pak Agusta Herdhata for constructive cooperation in the project. The authors also thank Surya Darma Tarigan for data on the external trunk water storage capacity of oil palm trunks, Dodo Gunawan for providing long-term climatic data and Martyna Kotowska for stand structural data. A big "Thank you!” also to everyone in Göttingen, Bogor and Jambi that made this work possible. Terimakasih! 


\section{References}

Allen, K., Corre, M., Tjoa, A., Veldkamp, E., 2015. Soil nitrogencycling response to conversion of lowland forests to oil palm and rubber plantations in Sumatra, Indonesia. PLoS ONE, 10, e0133325.

Baldocchi, D., 2003. Assessing the eddy covariance technique for evaluating carbon dioxide exchange rates of ecosystems: past, present and future. Global Change Biology, 9, 479-492.

Banabas, M., Turner, M. A., Scotter, D. R., Nelson, P. N., 2008. Losses of nitrogen fertiliser under oil palm in Papua New Guinea: 1. Water balance, and nitrogen in soil solution and runoff. Australian Journal of Soil Research, 46, 332-339.

Barnes, A. D., Jochum, M., Mumme, S., Haneda, N. F., Farajallah, A., Widarto, T. H., Brose, U., 2014. Consequences of tropical land use for multitrophic biodiversity and ecosystem functioning. Nature Communications, 5, 5351.

Becker, P., 1996. Sap flow in Bornean heath and dipterocarp forest trees during wet and dry periods. Tree Physiology, 16, 295-299

Breure, C. J., 1982. Factors affecting yield and growth of oil palm tenera in West New Britain. Oléagineux, 37, 213-227.

Calder, I. R., Wright, I. R., Murdiyarso, D., 1986. A study of evaporation from tropical rain forestWest Java. Journal of Hydrology, 89, 13-31.

Cienciala, E., Ku cera, J., and Malmer, A., 2000. Tree sap flow and stand transpiration of two Acacia mangium plantations in Sabah, Borneo. Journal of Hydrology, 236, 109-120.

Comte, I., Colin, F., Whalen, J. K., Grünberger, O., Caliman, J. P., 2012. Agricultural practices in oil palm plantations and their impact on hydrological changes, nutrient fluxes and water quality in Indonesia. Advances in Agronomy, 116, 71-124.

Cornish, P. M., Vertessy, R. A., 2001. Forest age-induced changes in evapotranspiration and water yield in a eucalypt forest. Journal of Hydrology, 242, 43-63.

Delzon, S., Loustau, D., 2005. Age-related decline in stand water use: sap flow and transpiration in a pine forest chronosequence. Agricultural Forest and Meteorology, 129, 105-119.

Dierick, D., Hölscher, D., 2009. Species-specific tree water use characteristics in reforestation stands in the Philippines. Agricultural Forest and Meteorology, 149, 1317-1326.

Dierick, D., Kunert, N., Köhler, M., Schwendenmann, L., Hölscher, D., 2010. Comparison of tree water use characteristics in reforestation and agroforestry stands across the tropics, in: Tropical Rainforests and Agroforests under Global Change, edited by: Tscharntke, T., Leuschner, C., Veldkamp, E., Faust, H., Guhardja, E., and Bidin, A., Environmental Science and Engineering, Springer Berlin Heidelberg, Berlin, Heidelberg, 293-308.

Drescher, J., Rembold, K., Allen, K., Beckschäfer, P., Buchori, D., Clough, Y., Faust, H., Fauzi, A.M., Gunawan, D., Hertel, D., et al., 2016. Ecological and socio-economic functions across tropical land use systems after rainforest conversion. Philosophical Transactions of the Royal Society B: Biological Sciences, 371, 20150275.

Dufrene, E., Saugier, B., 1993. Gas exchange of oil palm in relation to light, vapour pressure deficit, temperature and leaf age. Functional Ecology, 97-104.

Dykes, A. P., Rainfall interception from a lowland tropical rainforest in Brunei. Journal of Hydrology, 200, 260-279. 
Easmus, D., Cole, S., 1997. Diurnal and seasonal comparisons of assimilation, phyllode conductance and water potential of three Acacia and one Eucalyptus species in the Wet-Dry tropics of Australia. Australian Journal of Botany, 45, 275-290.

FAO, 2014. FAOSTAT online statistical service, Food and Agriculture Organization of the United Nations, Rome. Available at: http://faostat3.fao.org/ (last access: 19 March 2015).

Goldstein, G., Andrade, J. L., Meinzer, F. C., Holbrook, N. M., Cavelier, J., Jackson, P., Celis, A., 1998. Stem water storage and diurnal patterns of water use in tropical forest canopy trees, Plant, Cell \& Environment, 21, 397-406.

Granier, A., 1985. Une nouvelle méthode pour la mesure du flux de sève brute dans le tronc des arbres. Annals of Forest Science, 42, 193-200.

Guillaume, T., Muhammad, D., Kuzyakov, Y., 2015. Losses of soil carbon by conversion of tropical forest to plantations: Erosion and decomposition estimated by $\delta^{13} \mathrm{C}$. Global Change Biology, $21,3548-3560$.

Henson, I. E., 1999. Notes on oil palm productivity. IV. Carbon dioxide gradients and evapotranspiration, above and below the canopy. Journal of Oil Palm Research, 11, 33-40.

Henson, I. E., Dolmat, M. T., 2003. Physiological analysis of an oil palm density trial on a peat soil. Journal of Oil Palm Research, 15, 1-27.

Henson, I. E., Harun, M. H., 2005. The influence of climatic conditions on gas and energy exchanges above a young oil palm stand in north Kedah. Journal of Oil Palm Research, 17, 73-91.

Holbrook, N. M., Sinclair, T. R., 1992. Water balance in the arborescent palm, Sabal palmetto. II. Transpiration and stem water storage. Plant, Cell \& Environment, 15, 401-409.

Hollinger, D. Y., Kelliher, F. M., Schulze, E. D., Köstner, B. M. M., 1994. Coupling of tree transpiration to atmospheric turbulence. Nature, 371, 60-62.

Horna, V., Schuldt, B., Brix, S., Leuschner, C., 2011. Environment and tree size controlling stem sap flux in a perhumid tropical forest of Central Sulawesi, Indonesia. Annals of Forest Science, 68, 1027-1038.

Jayasuriya, M., Dunn, G., Benyon, R. O., Shaughnessy, P. J., 1993. Some factors affecting water yield from mountain ash (Eucalyptus regnans) dominated forests in south-east Australia. Journal of Hydrology, 150, 345-367.

Johnson, D. M., McCulloh, K. A., Meinzer, F. C., Woodruff, D. R., Eissenstat, D. M., 2011. Hydraulic patterns and safety margins, from stem to stomata, in three eastern U.S. tree species. Tree Physiology, 31, 659-668.

Kallarackal, J., Jeyakumar, P., George S. J., 2004. Water use of irrigated oil palm at three different arid locations in Peninsular India. Journal of Oil Palm Research, 16, 45-53.

Kelliher, F. M., Köstner, B., Hollinger, D. Y., Byers, J. N., Hunt, J. E., McSeveny, T. M., Meserth, R., Weir, P. L., Schulze, E. D., 1992. Evaporation, xylem sap flow, and tree transpiration in a New Zealand broad-leaved forest. Agricultural Forest and Meteorology, 62, 53-73.

Köhler, M., Dierick, D., Schwendenmann, L., Hölscher, D., 2009. Water use characteristics of cacao and Gliricidia trees in an agroforest in Central Sulawesi, Indonesia. Ecohydrology, 2, 520529.

Köhler, M., Hanf, A., Barus, H., Hölscher, D., 2013. Cacao trees under different shade tree shelter: effects on water use. Agroforestry Systems, 88, 63-73. 
Komatsu, H., Onozawa, Y., Kume, T., Tsuruta, K., Kumagai, T., Shinohara, Y., Otsuki, K., 2010. Stand-scale transpiration estimates in a Moso bamboo forest: II. Comparison with conifer-ous forests. Forest Ecology and Management, 260, 1295-1302.

Kotowska, M.M., Leuschner, C., Triadiati, T., Meriem, S., Hertel, D., 2015. Quantifying above and belowground biomass carbon loss with forest conversion in tropical lowlands of Sumatra (Indonesia). Global Change Biology, 21, 3620-3634.

Kumagai, T., Saitoh, T. M., Sato, Y., Takahashi, H., Manfroi, O. J., Morooka, T., Kuraji, K., Suzuki, M., Yasunari, T., Komatsu, H., 2005. Annual water balance and seasonality of evapotranspiration in a Bornean tropical rainforest. Agricultural Forest and Meteorology, 128, 81-92.

Larsen, R. K., Jiwan, N., Rompas, A., Jenito, J., Osbeck, M., Tarigan, A., 2014. Towards "hybrid accountability" in EU biofuels policy? Community grievances and competing water claims in the Central Kalimantan oil palm sector. Geoforum, 54, 295-305.

Madurapperuma, W. S., Costa, W. de, Sangakkara, U. R., Jayasekara, C., 2009. Estimation of water use of mature coconut (Cocos nucifera L.) cultivars (CRIC 60 and CRIC 65) grown in the low country intermediate zone using the compensation heat pulse method (CHPM). Journal of the National Science Foundation of Sri Lanka, 37, 175-186.

Mauder, M., Foken, T., 2006. Impact of post-field data processing on eddy covariance flux estimates and energy balance closure. Meteorologische Zeitschrift, 15, 97-609.

McJannet, D., Fitch, P., Disher, M., Wallace, J., 2007. Measurements of transpiration in four tropical rainforest types of north Queensland, Australia. Hydrological Process, 21, 3549-3564.

McNaughton, K. G., Jarvis, P. G., 1983. Water Deficits and Plant Growth: Predicting Effects of Vegetation Changes on Transpiration and Evaporation, Academic Press, New York, US.

Mei, T., Fang, D., Röll, A., Niu, F., Hendrayanto, Hölscher, D., 2015. Water use patterns of four tropical bamboo species assessed with sap flux measurements. Frontiers in Plant Science, 6, 1202.

Meijide, A., Röll, A., Fan, Y., Herbst, M., Niu, F., Tiedemann, F., June, T., Rauf, A., Hölscher, D., Knohl, A., Controls of water and energy fluxes in oil palm plantations: effect of environmental variables and oil palm age. In review.

Meinzer, F. C., Hinckley, T. M., Ceulemans, R., 1997. Apparent responses of stomata to transpiration and humidity in a hybrid poplar canopy. Plant, Cell \& Environment, 20, 1301-1308.

Merten, J., Röll, A., Guillaume, T., Meijide, A., Tarigan, S., Agusta, H., Dislich, C., Dittrich, C., Faust, H., Gunawan, D., et al., 2016. Water scarcity and oil palm expansion: social views and environmental processes. Ecology and Society, 21, 5

Morgan, P. H., Mercer, L. P., Flodin, N. W., 1975. General model for nutritional responses of higher organisms. Proceedings of the National Academy of Sciences, 72, 4327-4331.

Niu, F., Röll, A., Hardanto, A., Meijide, A., Köhler, M., Hendrayanto, Hölscher, D., 2015. Oil palm water use: calibration a sap flux method and a field measurement of scheme. Tree Physiology, $35,563-573$.

Obidzinski, K., Andriani, R., Komarudin, H., Andrianto, A., 2012. Environmental and social impacts of oil palm plantations and their implications for biofuel production in Indonesia. Ecology and Society, 17, 25. 
O’Grady, A. P., Eamus, D., Hutley, L. B., 1999. Transpiration increases during the dry season: patterns of tree water use in eucalypt open-forests of northern Australia. Tree Physiology, 19, 591-597.

Prior, L. D., Eamus, D., Duff, G. A., 1997. Seasonal trends in carbon assimilation, stomatal conductance, pre-dawn leaf water potential and growth in Terminalia ferdinandiana, a deciduous tree of northern Australian savannas. Australian Journal of Botany, 45, 53-69.

Radersma, S., Ridder, N. de, 1996. Computed evapotranspiration of annual and perennial crops at different temporal and spatial scales using published parameter values. Agricultural Water Management, 31, 17-34.

R Development Core Team, 2014. R: a language and environment for statistical computing. R Foundation for Statistical Computing, Vienna, Austria.

Renninger, H. J., Phillips, N., Hodel, D. R., 2009. Comparative hydraulic and anatomic properties in palm trees (Washingtonia robusta) of varying heights: implications for hydraulic limitation to increased height growth. Trees, 23, 911-921.

Renninger, H. J., Phillips, N., Salvucci, G. D., 2010. Wet- vs. dryseason transpiration in an Amazonian rain forest palm Iriartea deltoidea. Biotropica, 42, 470-478.

Richardson, A. D., Hollinger, D. Y., Burba, G. G., Davis, K. J., Flanagan, L. B., Katul, G. G., Munger, J. W., Ricciuto, D. M., Stoy, P. C., Suyker, A. E., et al., 2006. A multi-site analysis of random error in tower-based measurements of carbon and energy fluxes. Agricultural Forest and Meteorology, 136, 1-18.

Roberts, S., Vertessy, R., Grayson, R., 2001. Transpiration from Eucalyptus sieberi (L. Johnson) forests of different age. Forest Ecology and Management, 143, 153-161.

Roupsard, O., Bonnefond, J. M., Irvine, M., Berbigier, P., Nouvellon, Y., Dauzat, J., Taga, S., Hamel, O., Jourdan, C., Saint-André, L., et al., 2006. Partitioning energy and evapo-transpiration above and below a tropical palm canopy. Agricultural Forest and Meteorology, 139, 252-268.

Ryan, M. G., Phillips, N., Bond, B. J., 2006. The hydraulic limitation hypothesis revisited. Plant, Cell \& Environment, 29, 367-381.

Tani, M., Nik, A. R., Ohtani, Y., Yasuda, Y., Sahat, M. M., Kasran, B., Takanashi, S., Noguchi, S., Yusop, Z., Watanabe, T., 2003a. Characteristics of energy exchange and surface conductance of a tropical rain forest in peninsular Malaysia. Edited by: Pasoh, Okuda, T., Manokaran, N., Matsumoto, Y., Niiyama, K., Thomas, S. C., Ashton, P. S., Springer, Tokyo, Japan, 73-88.

Tani, M., Nik, A. R., Yasuda, Y., Noguchi, S., Shamsuddin, S. A., Sahat, M. M., Takanashi, S., 2003b. Long-term estimation of evapotranspiration from a tropical rain forest in Peninsular Malaysia. In: Water Resources Systems-Water Availability and Global Change, edited by: Franks, S., Bloeschl, G., Kumagai, M., Musiake, K., Rosbjerg, D., IAHS Publ. No. 280, IAHS Press, Wallingford, UK, 267-274.

Thomas, D. S., Eamus, D., Shanahan, S., 2000. Influence of season, drought and xylem ABA on stomatal responses to leaf-toair vapour pressure difference of trees of the Australian wet-dry tropics. Australian Journal of Botany, 48, 143-151.

Thomas, D. S., Eamus, D., 2002. Seasonal patterns of xylem sap pH, xylem abscisic acid concentration, leaf water potential and stomatal conductance of six evergreen and deciduous Australian savanna tree species. Australian Journal of Botany, 50, 229-236. 
Vanclay, J. K., 2009. Managing water use from forest plantations. Forest Ecology and Management, 257, 385-389.

Vertessy, R. A., Watson, F. G., O, Sullivan, S. K., 2001. Factors determining relations between stand age and catchment water balance in mountain ash forests. Forest Ecology and Management, $143,13-26$.

Waring, R. H., Running, S. W., 1978. Sapwood water storage: its contribution to transpiration and effect upon water conductance through the stems of old-growth Douglas-fir. Plant, Cell \& Environment, 1, 131-140.

Waring, R. H., Whitehead D., Jarvis, P. G., 1979. The contribution of stored water to transpiration in Scots pine. Plant, Cell \& Environment, 2, 309-317.

Williams, M., Malhi, Y., Nobre, A. D., Rastetter, E. B., Grace, J., Pereira, M. G. P., 1998. Seasonal variation in net carbon exchange and evapotranspiration in a Brazilian rain forest: a modeling analysis. Plant, Cell \& Environment, 21, 953-968.

Yoder, B. J., Ryan, M. G., Waring, R. H., Schoettle, A. W., Kaufmann, M. R., 1994. Evidence of reduced photosynthetic rates in old trees. Forest Science, 40, 513-527.

Yusop, Z., Chong, M. H., Garusu, G. J., Ayob, K., 2008. Estimation of evapotranspiration in oil palm catchments by short-term period water-budget method. Malaysian Journal of Civil Engineering, 20, 160-174.

Zeppel, M., Murray, B. R., Barton, C., Eamus, D., 2004. Seasonal responses of xylem sap velocity to VPD and solar radiation during drought in a stand of native trees in temperate Australia. Functional Plant Biology, 31, 461-470.

Zimmermann, M. H., 1973. The monocotyledons: their evolution and comparative biology IV. Transport problems in arborescent monocotyledons. The Quarterly Review of Biology, 48, 314-321. 
Table 4.1 Stand locations, characteristics and study periods.

\begin{tabular}{|c|c|c|c|c|c|c|c|c|c|}
\hline Plot code & Location/Village name & $\begin{array}{l}\text { Age } \\
\text { (yrs) }\end{array}$ & Study region $^{*}$ & Coordinates & $\begin{array}{c}\text { Altitude } \\
\text { (m) }\end{array}$ & Stand type $^{\dagger}$ & Study period & $\begin{array}{l}\text { Radiation/VPD } \\
\left(\mathrm{MJ} \mathrm{m}^{-2} \mathrm{~d}^{-1} / \mathrm{kPa}\right)\end{array}$ & $\begin{array}{l}\text { Radiation/VPD } \\
\left(\mathrm{MJ} \mathrm{m}^{-2} \mathrm{~d}^{-1} / \mathrm{kPa}\right)\end{array}$ \\
\hline $\mathrm{PA}^{\S}$ & Pompa Air & 2 & $\mathrm{H}$ & $01^{\circ} 50.13 ' \mathrm{~S} ; 103^{\circ} 17.74^{\prime} \mathrm{E}$ & 75 & $\mathrm{~S}$ & 15.10.2013-14.1.2014 & $21.6 / 1.4$ & $16.6 / 1.1$ \\
\hline HAR_yg & Bungku & 3 & $\mathrm{H}$ & $01^{\circ} 55.4^{\prime} \mathrm{S} ; 103^{\circ} 15.67^{\prime} \mathrm{E}$ & 63 & $S$ & $28.9 .2013-24.10 .2013$ & 21.8/1.6 & $17.6 / 1.2$ \\
\hline BD_yg & Pematang Kabau & 5 & B & $01^{\circ} 58.83^{\prime} \mathrm{S} ; 102^{\circ} 36.31^{\prime} \mathrm{E}$ & 55 & $S$ & 9.7.2013-3.8.2013 & $17.4 / 1.5$ & $12.3 / 1.2$ \\
\hline BO5 & Lubuk Kepayang & 9 & B & $02^{\circ} 06.82^{\prime} \mathrm{S} ; 102^{\circ} 47.74^{\prime} \mathrm{E}$ & 65 & $\mathrm{~S}$ & $1-22.9 .2013$ & $20.4 / 1.6$ & $15.4 / 1.1$ \\
\hline $\mathrm{HO} 4$ & Pompa Air & 10 & B & $01^{\circ} 47.21^{\prime} \mathrm{S} ; 103^{\circ} 16.23^{\prime} \mathrm{E}$ & 48 & $\mathrm{~S}$ & 18.7.2013-5.8.2013 & 19.9/1.4 & $16.0 / 1.0$ \\
\hline BO4 & Dusun Baru & 11 & B & $02^{\circ} 03.03{ }^{\prime} \mathrm{S} ; 102^{\circ} 45.20^{\prime} \mathrm{E}$ & 34 & $\mathrm{~S}$ & $6-26.8 .2013$ & $22.9 / 1.8$ & $17.6 / 1.4$ \\
\hline $\mathrm{BO} 3$ & Lubuk Kepayang & 12 & $\mathrm{~B}$ & $02^{\circ} 04.25^{\prime} \mathrm{S} ; 102^{\circ} 47.51^{\prime} \mathrm{E}$ & 71 & $\mathrm{~S}$ & $3.7 .2013-30.9 .2013$ & $21.8 / 1.8$ & $16.1 / 1.2$ \\
\hline $\mathrm{PTPN6}^{\S}$ & $\begin{array}{c}\text { PT. Perkebunan } \\
\text { Nusantara } 6\end{array}$ & 12 & $\mathrm{H}$ & $01^{\circ} 41.58^{\prime} \mathrm{S} ; 103^{\circ} 23.46^{\prime} \mathrm{E}$ & 70 & $\mathrm{C}$ & 19.7.2014-20.12.2014 & $19.7 / 1.4$ & $16.7 / 1.1$ \\
\hline $\mathrm{BO} 2$ & Lubuk Kepayang & 13 & B & $02^{\circ} 04.53{ }^{\prime} \mathrm{S} ; 102^{\circ} 47.51^{\prime} \mathrm{E}$ & 84 & $S$ & $10.6 .2013-4.7 .2013$ & $24.9 / 2.1$ & $20.5 / 1.7$ \\
\hline $\mathrm{HO} 2$ & Bungku & 14 & $\mathrm{H}$ & $01^{\circ} 53.00^{\prime} \mathrm{S} ; 103^{\circ} 16.06^{\prime} \mathrm{E}$ & 55 & $\mathrm{~S}$ & 25.9.2013-19.11.2013 & $21.3 / 1.5$ & $17.0 / 1.2$ \\
\hline $\mathrm{HO} 1$ & Bungku & 16 & $\mathrm{H}$ & $01^{\circ} 54.59^{\prime} \mathrm{S} ; 103^{\circ} 15.97^{\prime} \mathrm{E}$ & 81 & $S$ & $9-30.8 .2013$ & 22.31 .9 & $18.5 / 1.5$ \\
\hline $\mathrm{HO} 3$ & Pompa Air & 17 & $\mathrm{H}$ & $01^{\circ} 51.47 \mathrm{~S} ; 103^{\circ} 18.46^{\prime} \mathrm{E}$ & 64 & $\mathrm{~S}$ & 7.12.2013-19.1. 2014 & $16.7 / 1.0$ & $13.0 / 0.8$ \\
\hline PTHI & PT.Humusindo & 18 & $\mathrm{H}$ & $01^{\circ} 57.72^{\prime} \mathrm{S} ; 103^{\circ} 15.84^{\prime} \mathrm{E}$ & 59 & $\mathrm{C}$ & $15.11 .2013-4.12 .2013$ & $17.5 / 1.1$ & $17.4 / 1.1$ \\
\hline BD_old & Pematang Kabau & 22 & B & $01^{\circ} 57.37^{\prime} \mathrm{S} ; 102^{\circ} 33.67^{\prime} \mathrm{E}$ & 73 & $S$ & $14-30.7 .2013$ & $15.1 / 1.4$ & $11.8 / 1.2$ \\
\hline HAR_old & Bungku & 25 & $\mathrm{H}$ & $01^{\circ} 56.69^{\prime} \mathrm{S} ; 103^{\circ} 16.70^{\prime} \mathrm{E}$ & 43 & $\mathrm{~S}$ & $30.9 .2013-1.11 .2013$ & $21.1 / 1.6$ & $17.1 / 1.2$ \\
\hline
\end{tabular}

* "H" stands for Harapan region, "B" stands for Bukit Duabelas region; ‘ "S” stands for small holding, "C" stands for company; ${ }^{\ddagger}$ data were ave-rages of three selected sunny days; ${ }^{\#}$ data were averages of the full measurement periods; ${ }^{\S}$ parallel sap flux and eddy covariance measurements; same sunny days used. 
Table 4.2 Summary table of results for all 15 oil palm stands. $R^{2}$ and $P$ values for linear regression and fitting a Hill function, respectively, are presented to explain variability in water use characteristics (i.e. maximum sap flux density, leaf water use, palm water use and stand transpiration) by the stand variables age, trunk height and sapwood area.

\begin{tabular}{|c|c|c|c|c|c|c|c|c|}
\hline & \multicolumn{2}{|c|}{$\begin{array}{c}\text { Maximum sap flux } \\
\text { density }\end{array}$} & \multicolumn{2}{|c|}{ Leaf water use } & \multicolumn{2}{|c|}{ Palm water use } & \multicolumn{2}{|c|}{ Stand transpiration } \\
\hline & $\begin{array}{c}\text { Linear } \\
\text { fit }\end{array}$ & $\begin{array}{c}\text { Hill } \\
\text { function }\end{array}$ & $\begin{array}{c}\text { Linear } \\
\text { fit }\end{array}$ & $\begin{array}{c}\text { Hill } \\
\text { function }\end{array}$ & $\begin{array}{c}\text { Linear } \\
\text { fit }\end{array}$ & $\begin{array}{c}\text { Hill } \\
\text { function }\end{array}$ & $\begin{array}{c}\text { Linear } \\
\text { fit }\end{array}$ & $\begin{array}{c}\text { Hill } \\
\text { function }\end{array}$ \\
\hline$\overline{\text { Age }}$ & n.s. & $\begin{array}{c}R^{2} \mathrm{adj}= \\
0.16^{* *}\end{array}$ & $\begin{array}{l}R^{2}= \\
0.31^{*}\end{array}$ & $\begin{array}{c}R^{2} \text { adj }= \\
0.61^{* *}\end{array}$ & n.s. & $\begin{array}{c}R^{2} \mathrm{adj}= \\
0.59^{* *}\end{array}$ & n.s. & $\begin{array}{l}R^{2} \mathrm{adj}= \\
0.45^{* *}\end{array}$ \\
\hline $\begin{array}{l}\text { Trunk } \\
\text { height }\end{array}$ & n.s. & $\begin{array}{l}R^{2} \mathrm{adj}= \\
0.15^{* *}\end{array}$ & $\begin{array}{l}R^{2}= \\
0.37^{*}\end{array}$ & $\begin{array}{l}R^{2} \text { adj }= \\
0.62^{* *}\end{array}$ & $\begin{array}{l}R^{2}= \\
0.32^{*}\end{array}$ & $\begin{array}{l}R^{2} \mathrm{adj}= \\
0.61^{* *}\end{array}$ & n.s. & $\begin{array}{l}R^{2} \mathrm{adj}= \\
0.44^{* *}\end{array}$ \\
\hline $\begin{array}{l}\text { Sapwood } \\
\text { area }\end{array}$ & n.s. & $\begin{array}{l}R^{2} \mathrm{adj}= \\
0.02^{* *}\end{array}$ & $\begin{array}{c}R^{2}= \\
0.41^{* *}\end{array}$ & $\begin{array}{l}R^{2} \mathrm{adj}= \\
0.60^{* *}\end{array}$ & $\begin{array}{c}R^{2}= \\
0.39^{* *}\end{array}$ & $\begin{array}{c}R^{2} \text { adj }= \\
0.61^{* *}\end{array}$ & $\begin{array}{c}R^{2}= \\
0.42^{* *}\end{array}$ & $\begin{array}{r}R^{2} \mathrm{adj}= \\
0.43^{* *}\end{array}$ \\
\hline
\end{tabular}

* for $P \leq 0.05,{ }^{* *}$ for the $P \leq 0.01$, n.s. for no significant relationship $(P>0.05)$. 
Table 4.3 Summary table of results for 12 oil palm stands, i.e. excluding three stands of yet unexplained much higher water use (PTPN6, BO5, and HO2). $R^{2}$ and $P$ values for linear regression and fitting a Hill function, respectively, are presented to explain variability in water use characteristics (i.e. maximum sap flux density, leaf water use, palm water use and stand transpiration) by the stand variables age, trunk height and sapwood area.

\begin{tabular}{|c|c|c|c|c|c|c|c|c|}
\hline & \multicolumn{2}{|c|}{$\begin{array}{l}\text { Maximum sap flux } \\
\text { density }\end{array}$} & \multicolumn{2}{|c|}{ Leaf water use } & \multicolumn{2}{|c|}{ Palm water use } & \multicolumn{2}{|c|}{ Stand transpiration } \\
\hline & $\begin{array}{l}\text { Linear } \\
\text { model }\end{array}$ & $\begin{array}{c}\text { Hill } \\
\text { function }\end{array}$ & $\begin{array}{l}\text { Linear } \\
\text { model }\end{array}$ & $\begin{array}{c}\text { Hill } \\
\text { function }\end{array}$ & $\begin{array}{l}\text { Linear } \\
\text { model }\end{array}$ & $\begin{array}{c}\text { Hill } \\
\text { function }\end{array}$ & $\begin{array}{l}\text { Linear } \\
\text { model }\end{array}$ & $\begin{array}{c}\text { Hill } \\
\text { function }\end{array}$ \\
\hline Age & n.s. & $\begin{array}{c}R^{2} \mathrm{adj}= \\
0.16^{* *}\end{array}$ & $\begin{array}{c}R^{2}= \\
0.67^{* *}\end{array}$ & $\begin{array}{c}R^{2} \text { adj }= \\
0.86^{* *}\end{array}$ & $\begin{array}{c}R^{2}= \\
0.63^{* *}\end{array}$ & $\begin{array}{l}R^{2} \mathrm{adj}= \\
0.87^{* *}\end{array}$ & n.s. & $\begin{array}{l}R^{2} \mathrm{adj}= \\
0.75^{* *}\end{array}$ \\
\hline $\begin{array}{l}\text { Trunk } \\
\text { height }\end{array}$ & n.s. & $\begin{array}{l}R^{2} \mathrm{adj}= \\
0.13^{* *}\end{array}$ & $\begin{array}{c}R^{2}= \\
0.60^{* *}\end{array}$ & $\begin{array}{l}R^{2} \text { adj }= \\
0.82^{* *}\end{array}$ & $\begin{array}{c}R^{2}= \\
0.56^{* *}\end{array}$ & $\begin{array}{l}R^{2} \mathrm{adj}= \\
0.86^{* *}\end{array}$ & n.s. & $\begin{array}{l}R^{2} \mathrm{adj}= \\
0.77^{* *}\end{array}$ \\
\hline $\begin{array}{l}\text { Sapwood } \\
\text { area }\end{array}$ & n.s. & $\begin{array}{c}R^{2} \mathrm{adj}= \\
0.01^{* *}\end{array}$ & $\begin{array}{c}R^{2}= \\
0.68^{* *}\end{array}$ & $\begin{array}{c}R^{2} \text { adj }= \\
0.80^{* *}\end{array}$ & $\begin{array}{c}R^{2}= \\
0.64^{* *}\end{array}$ & $\begin{array}{c}R^{2} \text { adj }= \\
0.85^{* *}\end{array}$ & $\begin{array}{c}R^{2}= \\
0.61^{* *}\end{array}$ & $\begin{array}{c}R^{2} \text { adj }= \\
.69^{* *}\end{array}$ \\
\hline
\end{tabular}

* for $P \leq 0.05, * *$ for the $P \leq 0.01$, n.s. for no significant relationship $(P>0.05)$. 

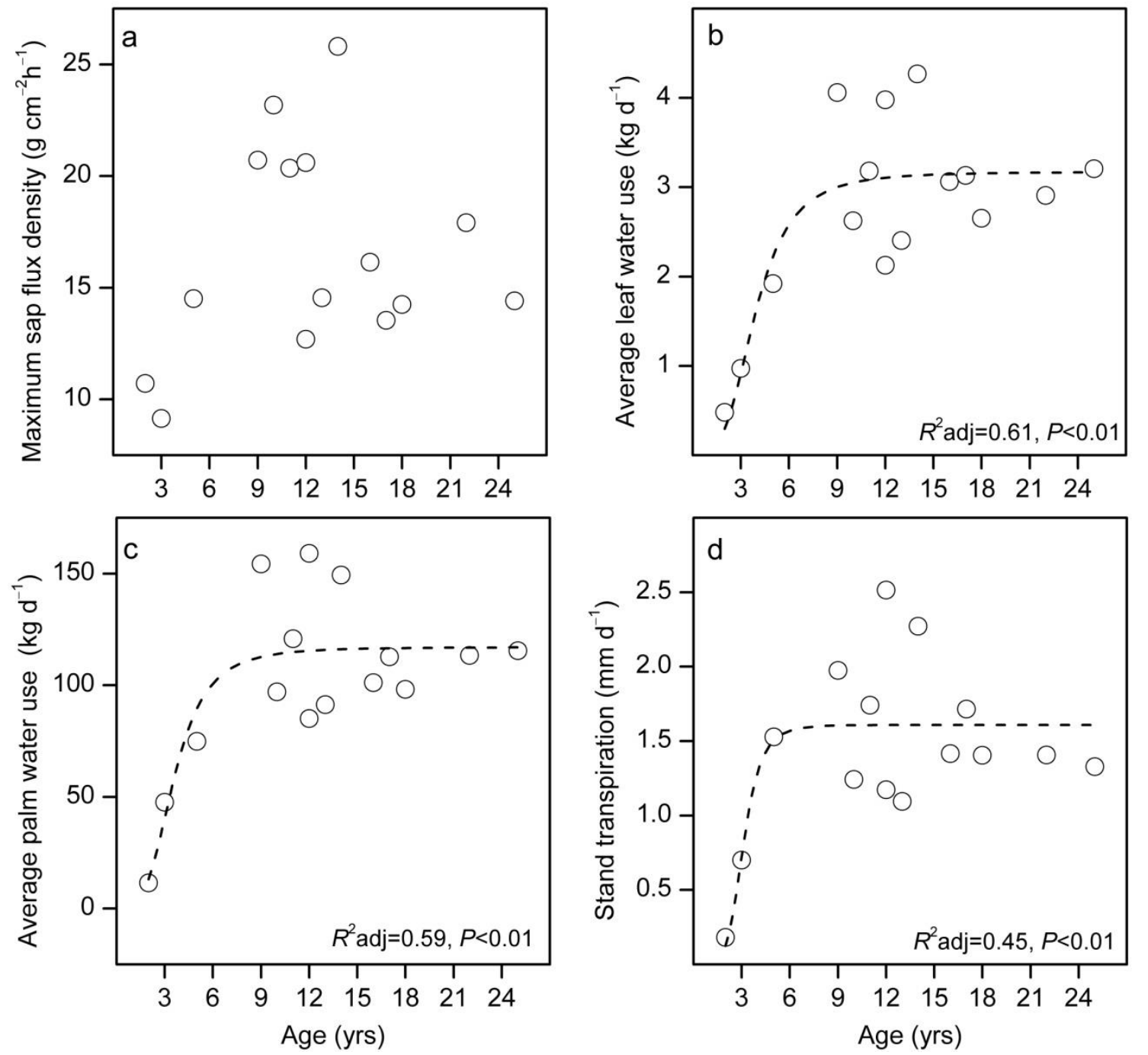

Appendix Figure 4.1 The change of maximum hourly sap flux density (a), average leaf water use (b), average palm water use (c) and stand transpiration (d) over stand age. Data of the different levels derived from simultaneous sap flux measurements on at least 13 leaves per stand; values of three sunny days averaged. The provided fits are Hill functions (dotted lines). 


\section{CHAPTER 5}

\section{RUBBER TREE TRANSPIRATION IN THE LOW- LANDS OF SUMATRA}

FurongNiu $^{1 * \dagger}$, Alexander Röll ${ }^{1 *}$, Ana Meijide ${ }^{2}$, Hendrayanto $^{3}$, Dirk Hölscher ${ }^{1}$

* The authors contributed equally to this work.

${ }^{1}$ Tropical Silviculture and Forest Ecology, Georg-August-Universität Göttingen, Germany

${ }^{2}$ Bioclimatology, Georg-August-Universität Göttingen, Germany

${ }^{3}$ Department of Forest Management, Institut Pertanian Bogor, Indonesia

${ }^{\dagger}$ Correspondence to: Furong Niu, Tropical Silviculture and Forest Ecology, Georg-AugustUniversität Göttingen, Büsgenweg 1, 37077 Göttingen, Germany. E-mail: $\underline{\text { fniu@ @gwdg.de }}$ 


\begin{abstract}
Since centuries, rubber trees (Hevea brasiliensis Muell. Arg.) have been cultivated in Asia and in the last decades their plantation area is expanding. From mainland Asia, high evapotranspiration rates from rubber tree plantations were reported and it was indicated that its transpiration responds sensitively to dynamics in environmental drivers. The present study was conducted in the lowlands of Sumatra, Indonesia, where rubber is grown by small-holders and maritime climatic conditions prevail. We assessed patterns of rubber tree water use as influenced by tree size, plantation age, and micrometeorological drivers by sap flux methods. Laboratory tests did not indicate the need to adjust the original calibration equation parameters for thermal dissipation probes (TDP). In a field trial, TDP measurement combined with radial profiles of sap flux density derived from heat field deformation sensors yielded tree water use rates similar to those obtained by the independent stem heat balance method. Sap flux was monitored on 10 on-farm plots in mono-cultural rubber plantations between 2 and 16 years old. Tree water use increased from young to about eight-year old plantations and then leveled off. In the older plantations, sap flux densities decreased with increasing tree diameter, which was not observed in the younger plantations. As a result, tree water use increased steeply with diameter in up to eight years old plantations, while the increase was much less pronounced in 14 and 16 year old plantations. Rubber tree transpiration showed a pronounced seasonality due to partial leaf shedding. Overall, the magnitude of transpiration was substantially lower than previously reported for rubber plantations on the Asian mainland. Potential reasons include differences in methods (eddy covariance vs. sap flux), management (more intensive on the Asian mainland) and climate (maritime in Sumatra and more continental on the mainland). In Sumatra, the expansion of oil palm plantations has raised concerns regarding periodic water scarcity. Rubber trees plantations may be of less concern due to their low transpiration rates and leaf-shedding in dry periods. In conclusion, our study endorses the importance of considering stand age, management, climate and species in eco-hydrological assessments of tropical plantation landscapes.
\end{abstract}

Keywords: age, climate, Hevea brasiliensis, transpiration, tree size, tropics, sap flux, land use, plantations 


\subsection{Introduction}

The area of rubber tree (Hevea brasiliensis Muell. Arg.) cultivation has also strongly increased throughout Southeast Asia (Qiu, 2009; Ziegler et al., 2009) and has directly and indirectly contributed to the decrease of natural tropical forests. There are concerns regarding biodiversity, climate but also the hydrological cycle. High evapotranspiration rates from rubber plantations in Thailand and Cambodia were recorded based on eddy covariance measurements (Giambelluca et al., 2016). Based on studies in southern China, it was proposed that rubber plantations act as "water pumps" and their evapotranspiration exceeds those of nearby natural forests (Tan et al., 2011). Sap flux measurements in Cambodia and Thailand on rubber trees resulted in lower transpiration estimates than those cited above but also indicated that rubber tree transpiration responds sensitively to dynamics in environmental drivers (Isarangkool Na Ayutthaya et al., 2011; Kobayashi et al., 2014).

Rubber tree cultivation for latex production has a century-long tradition in Indonesia and is one of the land uses that have largely gained in land cover. In recent decades, many types of land use including remaining natural forests and traditional rubber agroforestry system have been replaced by rubber monoculture plantations (Gouyou et al., 1993; Feintrenie and Levang, 2009). Indonesia has consequently become the second largest rubber producing country in the world (FAOSTAT, 2016). With regard to the climatic conditions, the "maritime continent" Indonesia and including the lowlands of Sumatra shows much lower seasonality than the Asian mainland and a more persistent cloud cover. Rubber plantations here are mainly owned and managed small-holders. In a comparison across land use types in Sumatran lowlands, rubber plantations had a much lower net primary productivity than remaining forests of oil palm plantations of the region and also a low standing biomass (Kotowska et al., 2015). It would hence seem plausible that also the transpiration by the Sumatran rubber plantations is low. Recently, concerns regarding temporal water scarcity and oil palm expansion have been raised (Merten et al., 2016), which were based on social and environmental studies. The eco-hydrological similarities and differences between oil palm and rubber plantations have not yet been addressed in more detail.

Our study was implemented in Jambi province in the lowlands of Sumatra. Here rubber cultivation has a long history but former studies often addressed the jungle rubber, rubber trees with admixed native trees (Van Noordwijk et al., 2012). In well accessible regions and near Jambi city, today oil palm cultivation prevails but further inland rubber plantations are (still) abundant, but much more in form of mono-cultural plantations. In our study we (1) assessed patterns of rubber tree water use as influenced by tree size, plantation age, and micro-meteorological drivers, and (2) relate the findings to previous studies of rubber tree water use from the Southeast Asian mainland and oil palms from the same region. The study is based on sap flux methods, and thus for an improved comparability we also 
conducted some laboratory and field experiments regarding the reliability of the employed methods before addressing the above listed topics.

\subsection{Methods}

\subsubsection{Study sites}

The field measurements were conducted in 10 small-holder rubber plantations (for stand characteristics see Appendix Table 5.1) in the lowlands of Jambi province, Indonesia (Figure 5.1). In the region, the average annual temperature was $26.7 \pm 1.0{ }^{\circ} \mathrm{C}$ (data from 1991 to 2011 ; mean $\pm \mathrm{SD}$ ). Annual precipitation was $2235 \pm 385 \mathrm{~mm}$. A period of relatively low rainfall $(<120 \mathrm{~mm}$ monthly precipitation), but no strong dry season usually occurred from June to September, but with considerable intra-annual variation. Soil types in the region are sandy and clay Acrisols (Drescher et al., 2016). The plantations were spread over two landscapes of lowland Jambi, with similar elevation of around $80 \mathrm{~m}$ a.s.l. The 10 studied plantations were between 2 and 17 years old. Eight belong to the core design of the "EFForTS" project (Drescher et al., 2016) and two were added to better cover low ages. All plantations are typical local small-holder sites under similar management. Both manual and chemical weeding was conducted throughout the year, while the plantations were not fertilized in the studied year (Allen et al., 2015).

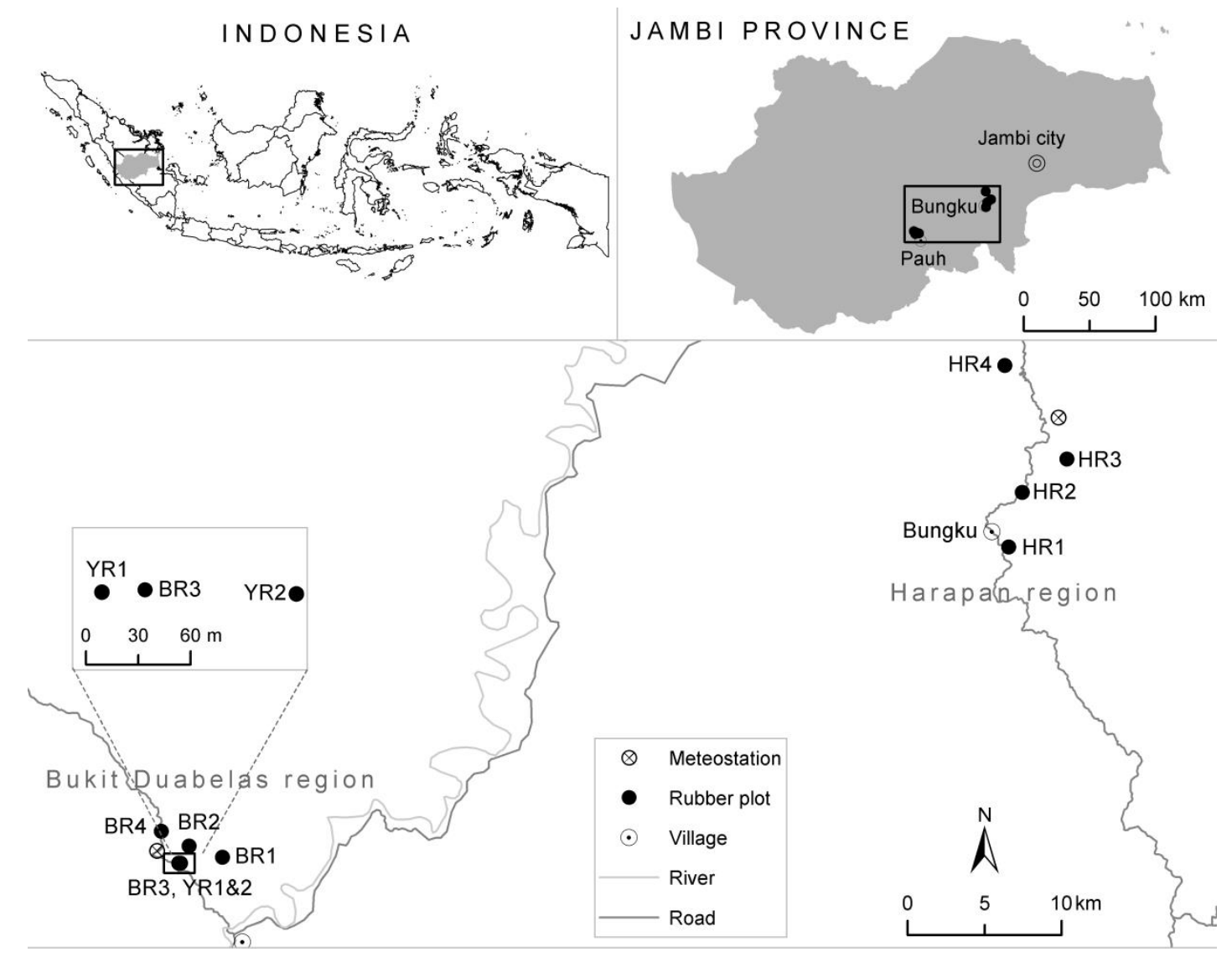

Figure 5.1 Locations of the 10 studied rubber plantations in Jambi province, Sumatra, Indonesia. 


\subsubsection{Sap flux measurements}

\subsubsection{Laboratory tests}

The tests of thermal dissipation probe (TDP) for measurements on rubber trees were conducted in the laboratory of the University of Jambi, Indonesia. We used the procedure described in detail for oil palm leaves (Niu et al., 2015). Water was pushed through segments equipped with TDPs and the water quantity was gravimetrically recorded. To prevent possible vessel blockage by latex exudate after cutting, the rubber segments were soaked in clear water for one night before the experiments started (Isarangkool Na Ayutthaya et al., 2010). In total, five rubber tree branches were used; average branch diameter was $6.04 \pm 0.28 \mathrm{~cm}$ (mean $\pm \mathrm{SD}$ ), the average length was $60 \pm 3 \mathrm{~cm}$.

\subsubsection{Field measurements}

Three sap flux techniques (thermal dissipation probe, heat field deformation and stem heat balance) were applied in a long-term monitoring plot (plot code: BR3; Appendix Table 5.1) located in a 7-yearold rubber plantation. Stand density was 464 trees per hectare. Average diameter (measured at ca. 1.7 m) was $14.5 \pm 2.4 \mathrm{~cm}$ (mean $\pm \mathrm{SD}$ ), average height was $13.2 \pm 1.3 \mathrm{~m}$ (Kotowska et al., 2015, also see Appendix Table 5.1). Ten trees of varying diameters (small to large) were selected for the TDP measurements; their average diameter was $16.2 \pm 2.3 \mathrm{~cm}$. On each tree, two $2.5 \mathrm{~cm}$-long TDP sensors were installed, in the South and North, respectively, ca. $30 \mathrm{~cm}$ above the area frequently cut for rubber extraction (commonly at around $2 \mathrm{~m}$ in height). After sensor installation, insulative materials and aluminum foil were used to cover the sensor in order to minimize temperature gradients and to reflect radiation. The sensors were connected to a multiplexer (AM16/32, Campbell Scientific Inc., Logan, USA), which was connected to a data logger (CR1000, Campbell Scientific Inc.). Data were recorded in $30 \mathrm{~s}$ intervals and averaged and stored every 10 minutes. Sap flux density $\left(J_{\mathrm{s}}, \mathrm{g} \mathrm{cm}^{-2} \mathrm{~h}^{-1}\right)$ was calculated with the original calibration equation by Granier (1985). Zero-flux nighttime conditions were examined following Oishi et al. (2008); during the whole respective measurement periods at all sites, the maximum temperature differences between the probes remained stable over hours when vapor pressure deficit (VPD) was below $0.05 \mathrm{kPa}$.

In five of the ten TDP sample trees (average diameter: $16.1 \pm 1.5 \mathrm{~cm}$ ), heat field deformation (HFD) sensors (ICT International Pty Ltd., Armidale, Australia) were installed in parallel to the TDP. The HFD sensors were installed approx. $30 \mathrm{~cm}$ below the TDP to avoid potential thermal interferences between the respective heating systems. This was confirmed in exploratory experiments before the measurements: when alternately turning on and off the systems over several hours during both the day and the night, sensors of neither system showed any reaction to turning on or off the respective other heating system. The first radial measurement point of the HFD sensors was placed at $0.25 \mathrm{~cm}$ depth, with seven more radial measurement points in $1 \mathrm{~cm}$ intervals. Simultaneous HFD and TDP measurements were conducted for at least 10 days on each tree. HFD data were stored separately as 10 
minute averages by built-in data loggers. The raw HFD-derived sap flux data were processed with the software Sap Flow Tool (version 1.4.1, ICT international Pty Ltd.).

Stem heat balance (SHB) measurements were conducted simultaneously with TDP measurements on four rubber trees (average diameter: $12.3 \pm 1.4 \mathrm{~cm}$ ) over periods of $2-3$ weeks. The SHB gauges (SGA100 and 150, Dynagage Inc., Huston, USA) were installed closely following the instructions of the user manual provided by the manufacturer (Dynamax, 2005) at a height of approx. $3.5 \mathrm{~m}$, more than one meter higher than the TDP sensors in order to avoid possible thermal interferences. As for the TDP measurements, data were recorded in $30 \mathrm{~s}$ intervals and stored as ten minutes averages by the same data logger. The raw data were processed as described in the Dynamax user manual. The wood thermal conductivity of rubber trees was set at the suggested value of $0.42 \mathrm{~J} \mathrm{~K}^{-1} \mathrm{~m}^{-1}$ for woody stems.

In the remaining nine rubber plantations (Appendix Table 5.1), only TDP measurements were conducted. Six trees per plot were selected to install two TDP sensors per tree, with the exception of a very young rubber plantation ( 2 yrs old), where only one sensor was installed per tree due to the small stem diameter $(<5 \mathrm{~cm})$. In the two young rubber plantations, four trees were selected per site. These two plots and trees will only be used for assessing age-related changes in tree water use. The measurements lasted 3-5 weeks per site, during different periods, but always in parallel to the measurements in the long-term monitoring plot (BR3). Sensor installation and other methodological aspects were identical to the above-described TDP setup in the BR3 plot.

\subsubsection{Tree water use and stand transpiration}

The individual daily tree water use of the sample trees was calculated by multiplying the TDP-derived sap flux density daysums by the respective "effective sapwood area $\left(\mathrm{SWA}_{\text {eff }}\right)$ ", i.e. the water conductive area taking into account radial changes in $J_{\mathrm{s}}$ and normalizing these by the TDP measurement depth (Oishi et al., 2008). For this, we first averaged the respective $J_{\mathrm{s}}$ daysum values of all available days for each of the 8 measurement depths. We then took these HFD-derived radial sap flux profiles and normalized the respective absolute $J_{\mathrm{s}}$ values of each of the 5 HFD sample trees by the mean $J_{\mathrm{s}}$ value (of all 5 trees) at a depth of $1.25 \mathrm{~cm}$, which constitutes the center of TDP sensor placement. The normalized values of all trees and measurement depths were then pooled, and a Gaussian function was fit to the data points to obtain a radial profile function of $J_{\mathrm{s}}$. Following Oishi et al. (2008), this allowed to calculate the diameter-dependent $\mathrm{SWA}_{\text {eff }}$ for each sample tree by multiplying the area below the Gaussian function by the distance from the centroid of the curve to the center of each respective tree. Using inventory data (i.e. tree diameter) for each plot (Kotowska et al., 2015) and the established function, the $\mathrm{SWA}_{\text {eff }}$ could be calculated for each tree in a respective stand, and consequently be summed up to obtain the stand $\mathrm{SWA}_{\text {eff. }}$. 
To derive individual tree water use rates, the respective $\mathrm{SWA}_{\text {eff }}$ were multiplied by the $J_{\mathrm{s}}$ daysums obtained as an average of the two sensors per sample tree. To calculate average tree water use rates for each plot, the respective average tree $\mathrm{SWA}_{\text {eff }}$ was multiplied by the average $J_{\mathrm{s}}$ of all sensors running simultaneously in the according plot; in analogy, stand transpiration rates were calculated by using the

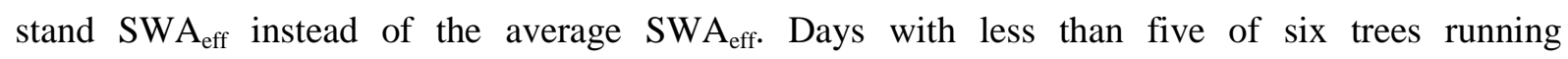
simultaneously per plot (or less than three of four trees in the two young rubber plots) were excluded from the analysis due to the high associated uncertainties of the estimate (see Kobayashi et al., 2014 for associated uncertainties with varying sample size in rubber trees). The whole measurement period in the long-term monitoring plot (BR3) was from 11.03.2013 to 22.01.2014 (with 305 days with at least five trees running simultaneously). For deriving the annual transpiration rate, the monthly averaged value between March and April, 2013 were used for filling the data gap in January and February, 2013, since they have quite similar climatic conditions and leaf coverage. For the comparison to TDP derived daily water use rates, SHB-derived $J_{\mathrm{s}}$ daysums were multiplied by the cross-sectional areas at the location of SHB sensor installation. This yielded SHB-derived daily water use rates for the four sample trees where simultaneous TDP and SHB measurements were performed.

\subsubsection{Environmental and phenological monitoring}

To analyze the influence of environmental drivers on rubber tree water use, data from a micrometeorological station set up in an open area about $2 \mathrm{~km}$ from the long-term monitoring plot was used (Figure 5.1). Air temperature and relative humidity were measured with a Thermohygrometer (type 1.1025.55.000, Thies Clima, Göttingen, Germany) to calculate vapor pressure deficit (VPD). A radiation sensor (CMP3 Pyranometer, Kipp \& Zonen, Delft, The Netherlands) was installed to measure global radiation $\left(R_{\mathrm{g}}, \mathrm{MJ} \mathrm{m}^{-2} \mathrm{~d}^{-1}\right.$, here after referred to as "radiation"). All meteorological data were recorded in $15 \mathrm{~s}$ intervals and stored as averages every ten minutes by a data logger (LogTrans 16-GPRS, UIT, Dresden, Germany). Additionally, a soil moisture sensor (Trime-Pico 32, IMKO, Ettlingen, Germany) was installed in the center of the long term monitoring plot, at a depth of $0.3 \mathrm{~m}$ into the soil; data were recorded hourly by a data logger (LogTrans 16-GPRS, UIT). However, during the whole measurement period in this plot, soil moisture never fell below $33 \mathrm{vol}$ \%, and exploratory analyses showed no significant relationship between soil moisture and water use rates. We thus excluded soil moisture from further analysis of environmental drivers for rubber tree water use, and the data are not shown. As rubber trees shed their leaves during dry periods, we regularly visually estimated the leaf-coverage (in $\%$ of full leaf-coverage) for each plot during the respective measurement periods. For the analysis, we subsequently distinguished between the fully-leaved and the partially-leaved period. 


\subsubsection{Data analysis}

For the long-term monitoring plot, the daily tree water use values from both fully-leaved (09.09.201322.01.2014; 125 days) and partially-leaved (13.06.2013-09.08.2013; 86 days) periods were plotted against VPD and $R_{\mathrm{g}}$ to examine the influence of micrometeorological drivers. For a further analysis of these micrometeorological drivers on rubber tree water use at the diurnal scale, the hourly values of three selected sunny $\left(R_{\mathrm{g}}>21.0 \mathrm{MJ} \mathrm{m}^{-2} \mathrm{~d}^{-1}\right)$ and three selected cloudy $\left(R_{\mathrm{g}}<9.5 \mathrm{MJ} \mathrm{m}^{-2} \mathrm{~d}^{-1}\right)$ days from the long-term monitoring plot were averaged, normalized (by setting the maximum to one) and plotted against $R_{\mathrm{g}}$ and VPD (also normalized) to examine occurrence, magnitude and pattern dynamics of hysteresis. These days were taken from the fully-leaved period. The same three sunny days were used to examine the relationship between individual tree water use and tree diameter in the long term monitoring plot (on 10 trees) and across five further mature stands measured during the fully-leaved period on their respective three sunny days (on six trees each).

The Wilcoxon signed-rank test was used to determine differences between TDP and gravimetric measurements in the laboratory calibration experiments, and the Mann-Whitney test was used to determine differences in transpiration rates of the long term monitoring plot between fully-leaved and partially-leaved periods, as these data were not distributed normally (Shapiro-Wilk normality test). The Student's t-test was used to determine differences in average tree water use and stand transpiration rates (respective averages of three sunny days) between four partially-leaved and five fully-leaved mature stands. All statistical analyses were performed using R version 3.1.1 (R Development Core Team, 2016).

\subsection{Results}

\subsubsection{Methods test}

\subsubsection{Laboratory}

The range of TDP-derived sap flux densities $\left(J_{\mathrm{S}_{-} \mathrm{TDP}}\right)$ covered in the laboratory calibration experiments on rubber branches ranged from 0 to $49 \mathrm{~g} \mathrm{~cm}^{-2} \mathrm{~h}^{-1}$ and thus fully covered the range observed during the field measurement campaign on rubber trunks $\left(0-45 \mathrm{~g} \mathrm{~cm}^{-2} \mathrm{~h}^{-1}\right)$. Half-hourly $J_{\mathrm{s}_{-} \text {TDP }}$ values in the experiments calculated with the original TDP calibration equation (Granier, 1985) showed a strong linear relationship with the sap flux density derived from gravimetric reference measurements $\left(J_{\mathrm{s}_{-} \text {grav }}\right.$, $R^{2}=0.96, P<0.001$, Figure 5.2a). There was a slight overestimation of $J_{\mathrm{s}}(4 \%$, Figure $5.2 \mathrm{a}$ ) in the TDP measurements compared to gravimetric measurements; however for better comparability with other studies we did not adjust for it. 


\subsubsection{Radial profiles in sap flux density}

In the five rubber trees measured with the HFD method, radial changes in $J_{\mathrm{s}}$ were similar, i.e. a clear decrease with increasing depth into the xylem (Figure 5.2b). A Gaussian function was fitted to the pooled data of the five trees $\left(R^{2}\right.$ adj $\left.=0.64, P<0.001\right)$. It indicates maximum $J_{\mathrm{s}}(100 \%)$ at a depth of $1.25 \mathrm{~cm}$ into the xylem and a drop to about $20 \%$ at a depth of $7.25 \mathrm{~cm}$, with some variation between the five sample trees. According to the fit, zero $J_{\mathrm{s}}$ is reached at a depth of $9.2 \mathrm{~cm}$. The Gaussian fit was used to derive a relationship between the DBH of rubber trees and their "effective sapwood area", i.e. their water conductive area taking into account the radial $J_{\mathrm{s}}$ changes and normalized for the standard TDP measurement depth $(1.25 \mathrm{~cm}$ ). The relationship (for a diameter range from 13.4-19.7 cm) was $\mathrm{SWA}_{\text {eff }}=16.436 *$ diameter $-113.62\left(R^{2}=0.99 ; P<0.001\right)$.

\subsubsection{Comparison of TDP and SHB measurements}

TDP-derived sap flux density daysums $\left(J_{\mathrm{S}_{-} \mathrm{TDP}}\right)$ were scaled-up to whole tree water use by multiplying them by the HFD-derived $\mathrm{SWA}_{\text {eff }}$ of the respective sample trees (see previous section). For four sample trees on which simultaneous TDP and SHB measurements were conducted, this allowed for a comparison of water use rates derived with the two techniques. Water use rates derived by TDP sensor were strongly correlated with SHB-derived values $\left(R^{2}=0.95, P<0.001\right.$, Figure 5.2c). Also, absolute water use rates derived by the two methods were quite similar: SBH-derived values were on average $12 \%$ higher.
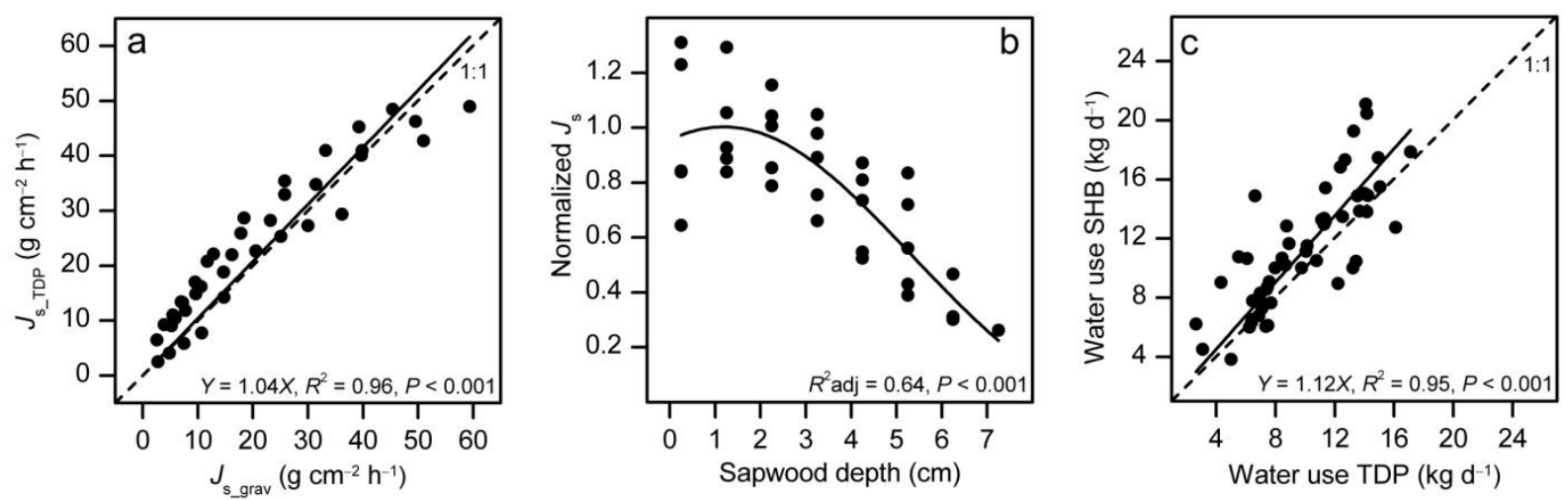

Figure 5.2 (a) Sap flux densities derived from gravimetric measurements $\left(J_{s_{-} \text {grav }}\right)$ and thermal dissipation probes $\left(J_{\mathrm{s}_{-} \text {TDP }}\right)$ using the original calibration equation (Granier, 1985). Pooled data from five rubber segments. (b) Changes of normalized $J_{\mathrm{s}}$ with increasing sapwood depth as measured by heat field deformation sensors on five rubber trees. Absolute daysum $J_{\mathrm{s}}$ from all measurement depths and trees were normalized by the mean value of the five trees at the center of TDP sensors. For each tree, the daysum $J_{\mathrm{s}}$ values of at least 10 days were averaged; the line represents a Gaussian fit. (c) Daily rubber tree water use derived from TDP vs. stem heat balance (SHB) measurements. TDP measurement were extrapolated to plant water use based on radial profile measurements. Pooled data from four trees, with at least two weeks of measurements per tree. 


\subsubsection{Patterns in rubber tree water use}

\subsubsection{Tree diameter and sap flux}

Maximal sap flux density $J_{s_{-} \max }$ tended to increase with (or showed no relationship to) tree diameter in 7 and 8 year old plantations. In contrast, $J_{s_{-} \max }$ decreased strongly with diameter in the more advanced plantations (14 and 16 yrs old) (Figure 5.3a). Consequently, in the younger plantations estimated tree water use increased steeply with diameter in the younger and less steep in the older plantations (Figure $5.3 b)$.
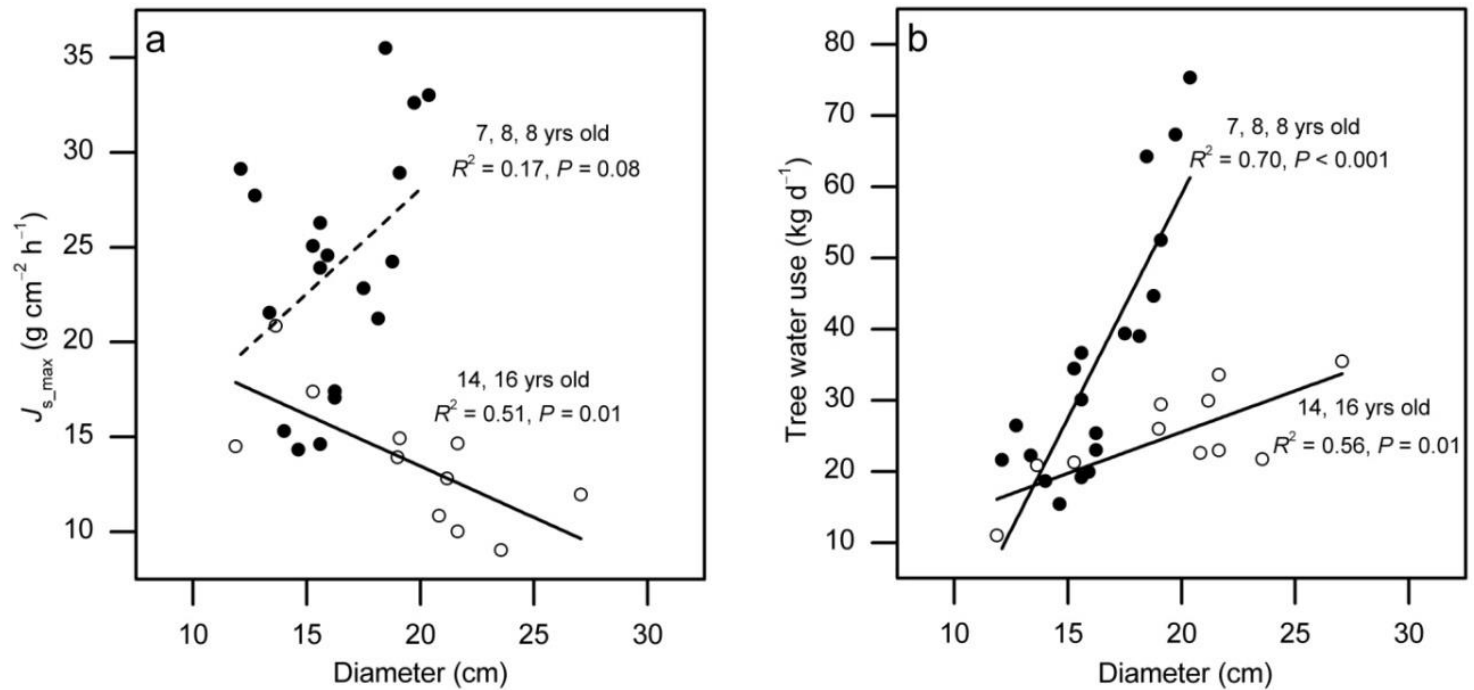

Figure 5.3 Sap flux density $\left(J_{s_{-} \max }\right)$ (a) and tree water use (b) in five mature rubber plantations when fully in leaves. Each point represents the mean value of three sunny days; solid points represent trees in relatively young rubber plantations ( $7-8$ yrs), hollow ones trees in older plantations (14-16 yrs). 


\subsubsection{Plantation age and water use}

During fully-leaved periods, mean rubber tree water use (average of three sunny days) was 3.0 and 9.6 $\mathrm{kg} \mathrm{d}^{-1}$ in two young plantations ( 2 and 5 yrs old, respectively). It was much higher (23.1 to $29.4 \mathrm{~kg} \mathrm{~d}^{-1}$ ) in five 7-16 year-old plantations (Figure 5.4). 64\% of the considerable spatial variability in rubber tree water use among the seven fully-leaved plots was explained by stand age (negative exponential function, $P<0.001$, Figure 5.4).

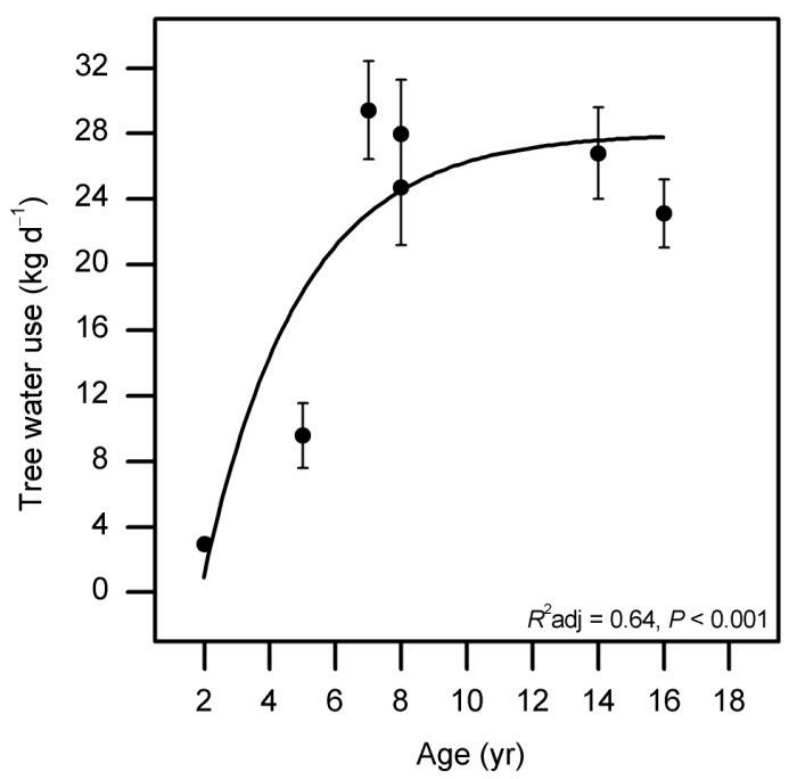

Figure 5.4 Average tree water use of fully-leaved rubber plantations $(n=7)$ with varying plantation age. Each point represents the mean tree water use of three selected sunny days; the error bars represent the according standard errors. A negative exponential function was fitted to the average tree water use values; the according $R^{2}$ adj and $P$-values are provided in the figure.

\subsubsection{Partial leaf-shedding}

Partial leaf-shedding occurred in three of the studied rubber plantations (HR2, HR3 and HR4, 40-70\% leaf-coverage) as well as, seasonally, in the long-term monitoring plot (30-60\% leaf-coverage, see Appendix Table 5.1). Leaf-shedding was not homogeneous and simultaneous over the study landscape, nor among the studied plots, and not even necessarily among the trees of a certain stand. As most of the studied rubber plots were studied successively rather than simultaneously, effects of partial leafshedding on spatial and temporal variability of rubber tree water use cannot always be clearly separated in this section.

In the long-term monitoring plot (BR3), the normalized tree water use decreased $25 \%$ from fullyleaved to partial leaf-shedding period (Figure 5.5). It also led to a higher plot-to-plot variability of normalized tree water use, which had a coefficient of variation of $10 \%$ among fully-leaved plots but $30 \%$ among partially leaved plots. 


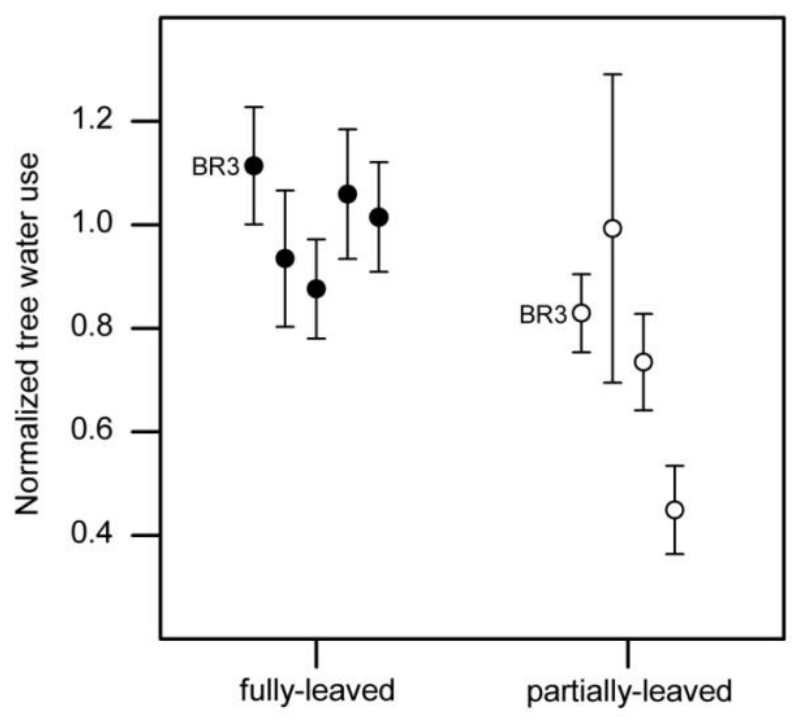

Figure 5.5 Normalized tree water use of different rubber plantations measured during the fully-leaved $(\mathrm{n}=5)$ and partially-leaved $(\mathrm{n}=4)$ periods, respectively. Normalization occurred by dividing average water use values of each plantation by the mean tree water use of all plantations measured during the fully-leaved period. Each point represents the mean tree water use of three selected sunny days, the error bars represent the according standard errors.

On our long-term monitoring plot BR3 periodical and partial leaf-shedding decreased stand transpiration from $1.1 \pm 0.02 \mathrm{~mm} \mathrm{~d}^{-1}$ (mean $\pm \mathrm{SE}$ ) during the fully-leaved period (125 days) to $0.9 \pm$ $0.02 \mathrm{~mm} \mathrm{~d}^{-1}$ during the partially-leaved period (86 days). The estimated annual stand transpiration rate was $395 \mathrm{~mm} \mathrm{yr}^{-1}$.

In both, the fully-leaved period and the partially-leaved period there was a significant linear increase of daily tree water use with $R_{\mathrm{g}}$ and VPD (Figure 5.6). However the slopes were much steeper in the fully-leaved period. Thus, differences in daily water use rates between the two periods were particularly pronounced at higher $R_{\mathrm{g}}$ or VPD, e.g. water use was $36 \%$ lower during the partially-leaved period at a VPD of $1 \mathrm{kPa}$ (Figure 5.6a).

We further assessed the micrometeorological drivers of temporal variability in rubber tree water use at the diurnal scale in the fully leaved period. On sunny days, pronounced hysteresis was observed for the normalized hourly tree water use response to VPD; the hysteresis to $R_{\mathrm{g}}$ was smaller (Figure 5.7a). Hourly tree water use increased quickly with increasing VPD or $R_{\mathrm{g}}$ in the early morning, and maximum water use rates were reached around 10 o'clock, when VPD was at $58 \%$ and $R_{\mathrm{g}}$ at $94 \%$ of their respective daily maxima. After reaching the maximum, rubber tree water use rates remained relatively high well into the afternoon, showing values of $95 \%$ of its daily maximum at the diurnal peak of VPD (at 14:00) and 98\% at the diurnal peak of radiation (at 13:00). Under cloudy conditions (Figure 5.7b), the areas of hysteresis to the micrometeorological drivers were considerably smaller for VPD but kept relatively consistent for $R_{\mathrm{g}}$. There was almost no hysteresis to VPD under cloudy 
conditions and water use responded almost proportionally to changes in VPD. Water use rates thus peaked much later in the day under cloudy conditions (13:00) than on sunny days.
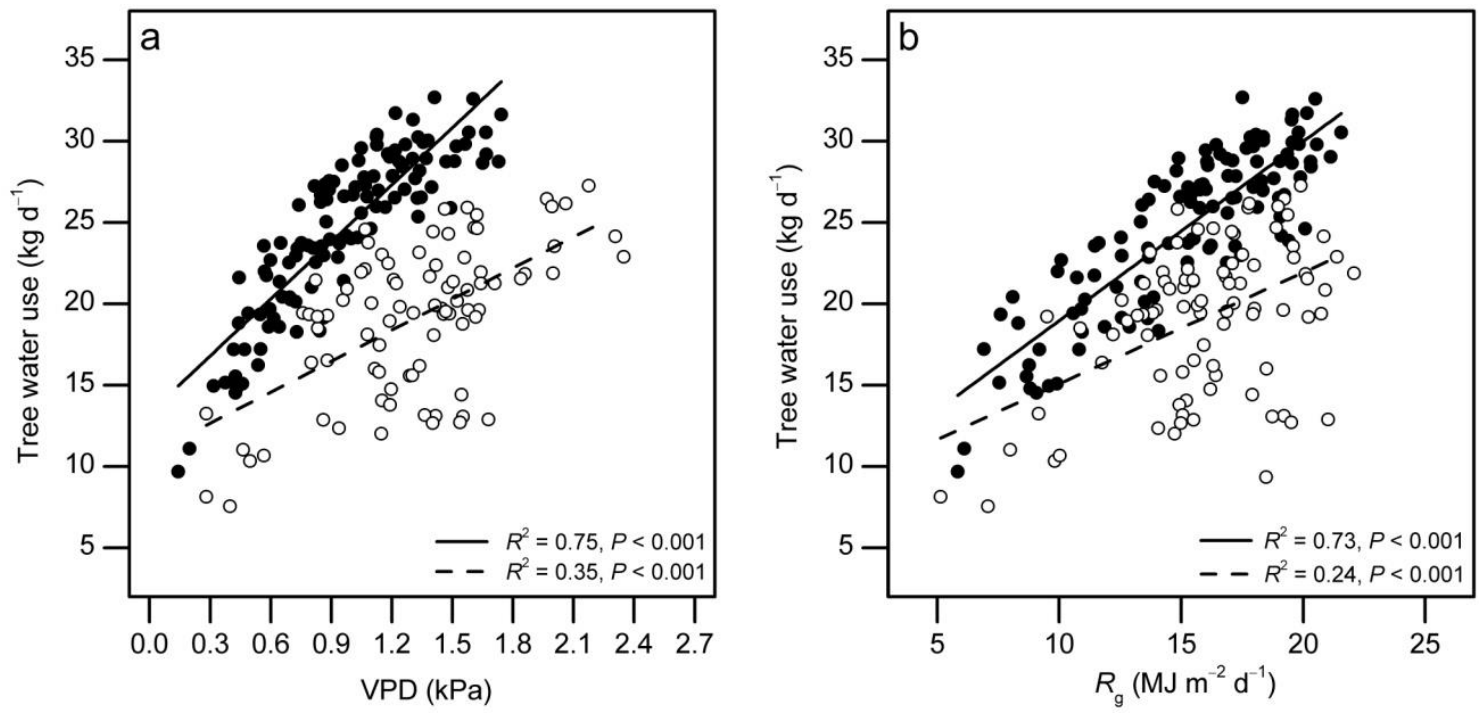

Figure 5.6 Rubber tree water use plotted against average daytime vapor pressure deficit (VPD) (a) and integrated daily radiation $\left(R_{\mathrm{g}}\right)(\mathrm{b})$. Tree water use rates derived from 10 trees measured in the longterm monitoring plot (BR3). Solid points represent days during the fully-leaved period, hollow points during the partially-leaved period. The solid lines represent the linear regressions during the fullyleaved period, dashed lines indicate the fitting during the partially-leaved period. According $R^{2}$ and $P$ values are provided in the panels.
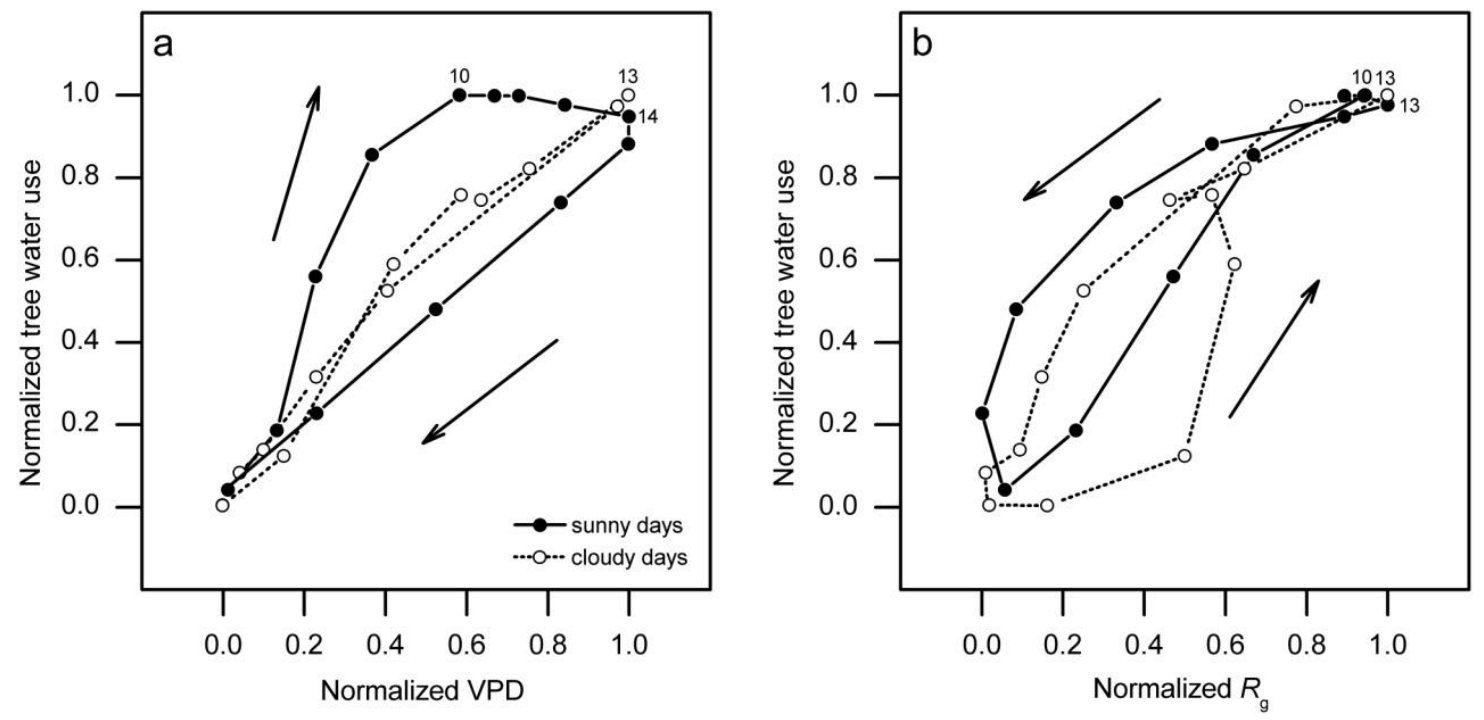

Figure 5.7 Normalized hourly tree water use rates plotted against normalized hourly vapor pressure deficit (VPD) (a) and radiation $\left(R_{\mathrm{g}}\right)(\mathrm{b})$ on three selected sunny and cloudy days during the fullyleaved period. Data were normalized by setting the respective diurnally observed maximum values to one. The normalized tree water use rates were the average of all sample trees in the long-term 
monitoring plot (BR3). The arrows indicate the order of observations, the numbers the respective times of day.

\subsection{Discussion}

\subsubsection{Methods test}

Compared to gravimetric reference measurements, our experiments showed only a slight overestimation of $J_{\mathrm{s}}$ by TDP sensors. Considering the small deviation and for better comparability with other studies, we decided to use the original calibration equation (Granier, 1985) for calculating $J_{\mathrm{s}}$ in rubber trees rather than deriving new, rubber-specific parameters. The process of scaling-up from TDP point measurement to per-tree water use is another potential source of estimation errors in sap flux derived water use rates (Oishi et al., 2008; Nadezhdina et al., 2012; Berdanier et al., 2016). The sharp (Gaussian) decrease in $J_{\mathrm{s}}$ that we found based on HFD measurements was of similar magnitude as radial $J_{\mathrm{s}}$ decreases reported by Isarangkool $\mathrm{Na}$ Ayutthaya et al. (2010) for rubber trees when measuring at different depths with the transient thermal dissipation probes technique. This is in line with the typical sap flux radial profiles for diffuse porous species which fitted by Gaussian and Gamma functions (Phillips et al. 1996; Zang et al., 1996; Berdanier et al., 2016). When comparing TDP and HFD scaled tree water use estimates with those derived from the independent SHB method, SHB values were by $12 \%$ higher. We cannot judge which method might be more reliable but a potential underestimation from our TDP and HFD based field monitoring must be considered. In addition, each value derived on the stand scale is subject to an uncertainty arising of the number of sample trees and sensors. Our number of sample trees and sensors is similar to that used by Kobayashi et al. (2014) in rubber trees, who estimated this uncertainty with $10 \%$ for values at the stand scale. However, our study was mainly designed for analyzing patterns in rubber tree water use which may arise from diameter relationship, age and response to climatic drivers.

\subsubsection{Patterns in rubber tree water use}

Among 30 trees measured in five fully-leaved mature rubber plantations, tree water use increased linearly with increasing tree diameter. That water use mainly scales with tree size is in accordance with several other studies on conifers and angiosperms (e.g. Meinzer et al., 2001, 2005). However, there were pronounced differences in our study between younger (7-8 yrs old) and older rubber trees (14-16 yrs). For older trees, the slope of the regression line between diameter and water use was 5fold lower than for younger trees, which, e.g. at a diameter of $20 \mathrm{~cm}$, results in a more than two-fold difference in water use. This divergence in water use between younger and older rubber trees was related to different patterns of $J_{s_{-} \max }$ with increasing tree diameters: In older trees, it was decreasing, while there was an increasing trend in younger trees. It has been postulated, that $J_{\mathrm{s}_{-} \max }$ universally 
decreases with increasing tree diameter ("functional convergence", Meinzer et al., 2001). However, the range of diameters in our study $(11-27 \mathrm{~cm})$ was likely too small to make this effect visible. This has also been shown in other studies with a similarly small covered diameter-range (Dierick and Hölscher 2009; Dierick et al., 2010; Köhler et al., 2010; Kunert et al., 2010). Potential reasons for the much lower and decreasing $J_{s_{-} \max }$ in older rubber trees as opposed to younger ones could be related to physiological damages after more than a decade of regular rubber extraction, which could also be related to productivity. It may also be due to changes in the planting material as modern clones only recently have been introduced in Jambi's small-holder agriculture.

Looking at the spatial variability of rubber tree water use among seven fully-leaved plots (2-16 yrs old), $64 \%$ of the variability in rubber tree water use among plots could be explained by varying plantation age. Similarly strong effects of plantation age on water use were demonstrated for oil palms (Elaeis guineensis Jacq.) in the study region: among 15 plantations between 2 and $25 \mathrm{yrs}$ old, $75 \%$ of the variability in water use could be explained by plantation age (Röll et al., 2015). Remaining unexplained variability of water use rates is likely due to differences in site characteristics. For example, for eight of the 10 rubber plots examined in this study, pronounced site-to-site variability in soil characteristics (e.g. with regard to nitrogen availability or soil organic carbon content) was reported (Allen et al., 2015; Guillaume et al., 2015). For partially-leaved plots, at least part of the considerate (i.e. three-fold higher than in fully-leaved plots) variability among four plots likely comes from heterogeneous leaf-coverage during the respective periods of measurement. While fully-leaved plots were relatively homogeneous (i.e. 100\% foliage), partially-leaved plots ranged from 30-70\% foliage (Appendix Table 5.1). In conclusion, the substantial spatial variability in rubber tree water use both within and among plots could to a large extent be explained by differences in stand characteristics (diameter, age and foliage).

Asides from substantial spatial variability in rubber tree water use due to varying stand and site characteristics, we also found pronounced temporal day-to-day variation in water use, particularly between the fully-leaved and the partially-leaved period. Data from our long-term monitoring plot suggest that leaf-shedding (reduction to $30-60 \%$ foliage) results in a reduction of water use of about $21 \%$. In our study area and period, the dry season was not very pronounced (precipitation events at least once a week), and leaf-shedding on rubber trees was not complete (max. 70\% shedding based on visual assessment), relatively short-term (several days to few weeks), successively (not simultaneously even in neighboring stands) and highly variable at small-scales (shedding and non-shedding trees occurred within single plots). In contrast to this, on the Asian mainland a much more pronounced and prolonged dry period (including e.g. drops in soil moisture to $10 \%$ ) goes along with more complete and homogeneous leaf-shedding, which consequently manifests itself in larger reductions of rubber tree water use compared to fully-leaved conditions (Isarangkool Na Ayutthaya et al., 2011; Kobayashi et al., 2014; Sopharat et al., 2014). 
Data from our long-term monitoring plot further suggests that differences in water use rates between fully-leaved and partially-leaved are particularly pronounced at high atmospheric evaporative demand, i.e. high VPD and radiation. The transpiration response to increases in VPD and radiation was more sensitive under fully-leaved conditions. Sensitive responses of (fully-leaved) rubber tree transpiration to changes in environmental drivers were also reported in studies from the Asian mainland (Kobayashi et al., 2014; Giambelluca et al., 2016).

For a closer analysis of the response of rubber tree water use to fluctuations in micrometeorological drivers, we took a look at the water use response to VPD and $R_{\mathrm{g}}$ at the diurnal scale and compared the data from sunny and cloudy days (both under fully-leaved conditions). On sunny days, the water use response was relatively closely coupled to $R_{\mathrm{g}}$ (i.e. small area of hysteresis), particularly before noon; under cloudy conditions, it was coupled closely to VPD (almost no hysteresis). This is different from mature oil palms in the same study region, where transpiration on sunny days increased early in the morning, but then declined consistently throughout the day despite further increasing radiation and VPD (Niu et al., 2015, Röll et al., 2015). Rubber, in contrast, continues to transpire at high rates well into the afternoon.

\subsubsection{Comparison with other rubber and oil palm transpiration data}

Regarding the magnitude of transpiration, mean rubber tree water use and stand transpiration rates of five mature, fully-leaved rubber plantations in Jambi, Indonesia were $26.4 \mathrm{~kg} \mathrm{~d}^{-1}$ and $1.3 \mathrm{~mm} \mathrm{~d}^{-1}$ under sunny conditions. While to our knowledge no values from other studies are available yet from maritime Indonesia, rubber transpiration rates from the Asian mainland have been reported to be substantially higher ( $2 \mathrm{~mm} \mathrm{~d}^{-1}$, Isarangkool $\mathrm{Na}$ Ayutthaya et al., 2011; Kobayashi et al., 2014; Sopharat et al., 2014). Also on the Asian mainland, evapotranspiration rates of rubber plantations, eddy covariance derived, have been reported to be as high as $4.0 \mathrm{~mm} \mathrm{~d}^{-1}$ and thus exceed those of natural forests in the same region (Tan et al., 2011; Giambelluca et al., 2016). For tropical tree-based ecosystems such as rubber plantations, transpiration is estimated to constitute $70 \pm 14 \%$ of total evapotranspiration (Schlesinger and Jasechko, 2014), combing with above-mentioned eddy covariance derived evapotranspiration rate $\left(4 \mathrm{~mm} \mathrm{~d}^{-1}\right)$, which yields relatively high transpiration estimates of 2.2 to $3.4 \mathrm{~mm} \mathrm{~d}^{-1}$. Transpiration estimates for the Asian mainland are thus at least $60 \%$ higher than the averages values we derived in our study. Studies on the Asian mainland covered similar stem diameter and stand age ranges as our study (Table 5.1); so it is unlikely that the differences in transpiration estimates arise from tree stand structural characteristics. Potential reasons for the differences include methods, management and climate. The estimates on the Asian mainland are mainly based on the eddy covariance technique. Due to many challenges when measuring with this technique, studies thus far encompass only few sites. When e.g. comparing those values to the single highest stand transpiration rate in our study $\left(1.5 \mathrm{~mm} \mathrm{~d}^{-1}\right)$, differences appear less pronounced than when using our five-plot- 
average $\left(1.3 \mathrm{~mm} \mathrm{~d}^{-1}\right.$, five fully-leaved plots). One study in central Cambodia using sap flux measurements at a single site to derive stand transpiration rates reported lower rubber transpiration rates (1.3 and $1.8 \mathrm{~mm} \mathrm{~d}^{-1}$ in two different years, Kobayashi et al., 2014). While, in the same plantation, eddy covariance derived evapotranspiration rate is much higher than sap flux derived transpiration rate (Giambelluca et al., 2016). One reason for the difference might be other sources of evapotranspiration such as the dense understory (see Table 5.1) or the soil which is measured by the eddy covariance but not the sap flux technique. However, lower estimates derived from sap flux than from eddy covariance are not unusual (Oishi et al., 2008; Kumagai et al., 2015).

More sophisticated management of rubber plantations on the Asian mainland may be a further reason for higher water use rates. Our study sites in Jambi, Indonesia were all small-holder properties. The studies on the Asian mainland were at least partially conducted in larger plantations (e.g. on an experimental farm in Cambodia; Kumagai et al., 2015; Giambelluca et al., 2016), where more sophisticated management, e.g. also with regard to optimal harvesting practices or the utilization of higher-yielding rubber varieties, may induce higher productivity, which would likely go along with higher rubber tree water use. Accordingly, net primary productivity of eight of the 10 rubber plantations in our study was relatively low $\left(7.7 \pm 1.1 \mathrm{Mg} \mathrm{ha}^{-1} \mathrm{yr}^{-1}\right.$, mean $\left.\pm \mathrm{SD}\right)$, e.g. $53 \%$ and $34 \%$ lower than that of oil palm plantations and forests in the region (Kotowska et al., 2015).

Climatically, the study sites on the continental Asian mainland (i.e. Cambodia and Thailand) have very different characteristics than our maritime study sites. Climate on the mainland is highly seasonal, with the clear annual cycles of precipitation, soil moisture and VPD (Kumagai et al., 2015; Giambelluca et al., 2016). It has been postulated that high rubber transpiration on the Asian mainland is sustained by a short leaf shedding period (around one to two months) and rapid leaf flushing in the late dry season, deep soil water extraction in times of limiting soil moisture conditions during the dry season and high water use in the wet season to compensate for a shortened growing season in the Asian monsoon region (Giambelluca et al., 2016). Comparing with Asian mainland studies, in the long-term monitoring plot we observed longer partially leaf-shedding period (from middle of June to middle of September) with lower transpiration rate although the soil water was not limited. The potential evapotranspiration during the rainy seasons in Asian mainland was above $1200 \mathrm{~mm} \mathrm{~d}^{-1}$ (see Figure 4 in Kumagai et al., 2015), which was even higher than the annual value for our studied area $\left(1150 \pm 10 \mathrm{~mm} \mathrm{~d}^{-1}\right.$; Meijide et al., in review) (Table 5.1). This substantial higher potential evapotranspiration rate during the rainy season could drive to the much higher transpiration rate comparing with our study. In conclusion, there are potential good reasons why besides methodological aspects rubber tree water use in small-holder plantation in Sumatra may be lower than those so far reported from the Asian mainland.

From Sumatra, water use rates of oil palm plantations are also available (Niu et al., 2015; Röll et al., 2015). The sap flux measurements have been well calibrated in the laboratory and seem reliable when 
comparing them with estimates by the eddy covariance measurements (Niu et al., 2015; Meijide et al., in review). Similar as this study the oil palm water use is also significantly affect by the stand age (Röll et al., 2015). During sunny conditions, the averaged transpiration rate of matured oil palm stands was $1.6 \mathrm{~mm} \mathrm{~d}^{-1}$, comparing with $1.3 \mathrm{~mm} \mathrm{~d}^{-1}$ in rubber plantations in this study, which was $30 \%$ lower. Interestingly, the highest oil palm transpiration rates $\left(2.5 \mathrm{~mm} \mathrm{~d}^{-1}\right)$ were recorded in the most intensively managed plantation. In addition, the rubber trees sharply decrease the transpiration by partially leaf shedding during relatively dry periods. These results suggest substantial differences in the annual transpiration rate between oil palm and rubber monocultures and may consequently affect the local hydrological cycles in the opposite direction. Recently, concerns regarding temporal water scarcity and oil palm expansion have been raised (Merten et al., 2016). Due to the overall lower transpiration rate, in particular due to the temporal leaf shedding, the concerns regarding rubber plantations in the eco-hydrological cycle in lowland Sumatra may be less than those of oil palm.

We conclude that there is substantial variability in transpiration even in mono-cultural rubber plantations. The study endorses the importance of considering climate, stand age and management in eco-hydrological assessments of tropical plantation landscapes.

\section{Acknowledgements}

This study was supported by a grant from the German Research Foundation (DFG, CRC 990, A02). Furong Niu received a scholarship from the China Scholarship Council (CSC). The authors thank Pak Agusta Herdhata and Pak Heri Junedi for constructive cooperation in the project and Andrea Hanf and our field assistants Bayu and Ferry for support in the field.

\section{References}

Allen, K., Corre, M., Tjoa, A., Veldkamp, E., 2015, Soil nitrogencycling response to conversion of lowland forests to oil palmand rubber plantations in Sumatra, Indonesia, PLoS ONE, 10, e0133325.

Allen, R.G., Pereira, L.S., Raes, D., Smith, M., 1998. Crop evapotranspiration-guidelines for computing crop water requirements-FAO Irrigation and Drainage Paper 56. Food and Agriculture Organization of the United Nations, Rome.

Berdanier, A.B., Miniat, C.F., Clark, J.S., 2016. Predictive models for radial sap flux variation in coniferous, diffuse-porous and ring-porous temperate trees. Tree Physiology, tpw027.

Dierick, D., Hölscher, D., 2009. Species-specific tree water use characteristics in reforestation stands in the Philippines. Agricultural and Forest Meteorology, 149, 1317-1326. 
Dierick, D., Hölscher, D., Schwendenmann, L., 2010.Water use characteristics of a bamboo species (Bambusa blumeana) in the Philippines. Agricultural Forest and Meteorology, 150, 15681578.

Drescher, J., Rembold, K., Allen, K., Beckschäfer, P., Buchori, D., Clough, Y., Faust, H., Fauzi, A.M., Gunawan, D., Hertel, D., et al., 2016. Ecological and socio-economic functions across tropical land use systems after rainforest conversion. Philosophical Transactions of the Royal Society B: Biological Sciences, 371, 20150275.

Dynamax, 2005. Dynagage sap flow sensor user manual. Dynamax Inc., Houston, USA. http://www.dynamax.com/images/uploads/papers/Dynagage_Manual.pdf (last access: 04.05.2016).

FAOSTAT, 2016. FAO online statistical service, Food and Agriculture Organization of the United Nations, Rome, Italy, available at: http://faostat3.fao.org/ (last access: 04.05.2016).

Feintrenie, L., Levang, P., 2009. Sumatra's rubber agroforests: advent, rise and fall of a sustainable cropping system. Small-scale Forestry, 8, 323-335.

Giambelluca, T.W., Mudd, R.G., Liu, W., Ziegler, A.D., Kobayashi, N., Kumagai, T.O., Miyazawa, Y., Lim, T.K., Huang, M., Fox, J., et al., 2016. Evapotranspiration of rubber (Hevea brasiliensis) cultivated at two plantation sites in Southeast Asia. Water Resources Research, 52, 660-679.

Gouyon, A., Foresta, H., Levang, P., 1993. Does 'jungle rubber' deserve its name? An analysis of rubber agroforestry systems in southeast Sumatra. Agroforest System, 22, 181-206.

Granier, A., 1985. Une nouvelle méthode pour la mesure du flux de sève brute dans le tronc des arbres. Annals of Forest Science, 42, 193-200.

Isarangkool Na Ayutthaya, S., Do, F.C., Pannengpetch, K., Junjittakarn, J., Maeght, J.L., Rocheteau, A., Cochard, H., 2010. Transient thermal dissipation method of xylem sap flow measurement: multi-species calibration and field evaluation. Tree Physiology, 30, 139-148.

Isarangkool Na Ayutthaya, S., Do, F.C., Pannangpetch, K., Junjittakarn, J., Maeght, J.L., Rocheteau, A., Cochard, H., 2011. Water loss regulation in mature Hevea brasiliensis: effects of intermittent drought in the rainy season and hydraulic regulation. Tree Physiology, 31, 751762.

Kobayashi, N., Kumagai, T.O., Miyazawa, Y., Matsumoto, K., Tateishi, M., Lim, T.K., Mudd, R.G., Ziegler, A.D., Giambelluca, T.W., Yin, S., 2014. Transpiration characteristics of a rubber plantation in central Cambodia. Tree Physiology, 34, 285-301.

Köhler, M., Dierick, D., Schwendenmann, L., Hölscher, D., 2009. Water use characteristics of cacao and Gliricidia trees in an agroforest in Central Sulawesi, Indonesia. Ecohydrology, 2, 520529.

Kotowska, M.M., Leuschner, C., Triadiati, T., Meriem, S. and Hertel, D., 2015. Quantifying aboveand belowground biomass carbon loss with forest conversion in tropical lowlands of Sumatra (Indonesia). Global Change Biology, 21, 3620-3634.

Kumagai, T.O., Mudd, R.G., Giambelluca, T.W., Kobayashi, N., Miyazawa, Y., Lim, T.K., Liu, W., Huang, M., Fox, J.M., Ziegler, A.D., et al., 2015. How do rubber (Hevea brasiliensis) plantations behave under seasonal water stress in northeastern Thailand and central Cambodia? Agricultural and Forest Meteorology, 213, 10-22.

Kunert, N., Schwendenmann, L., Hölscher, D., 2010. Seasonal dynamics of tree sap flux and water use in nine species in Panamanian forest plantations. Agricultural and Forest Meteorology, 150, $411-419$. 
Meijide, A., Röll, A., Fan, Y., Herbst, M., Niu, F., Tiedemann, F., June, T., Rauf, A., Hölscher, D., Knohl, A. Controls of water and energy fluxes in oil palm plantations: effect of environmental variables and oil palm age. In review.

Meinzer, F.C., Goldstein, G., Andrade, J.L., 2001. Regulation of water flux through tropical forest canopy trees: do universal rules apply? Tree Physiology, 21, 19-26.

Meinzer, F.C., Bond, B.J., Warren, J.M., Woodruff, D.R., 2005. Does water transport scale universally with tree size? Functional Ecology, 19, 558-565.

Merten, J., Röll, A., Guillaume, T., Meijide, A., Tarigan, S., Agusta, H., Dislich, C., Dittrich, C., Faust, H., Gunawan, D., et al., 2016. Water scarcity and oil palm expansion: social views and environmental processes. Ecology and Society, 21, 5

Nadezhdina, N., Vandegehuchte, M.W., Steppe, K., 2012. Sap flux density measurements based on the heat field deformation method. Trees, 26, 1439-1448.

Niu, F., Röll, A., Hardanto, A., Meijide, A., Köhler, M., Hendrayanto, Hölscher, D., 2015. Oil palm water use: calibration a sapflux method and a field measurement of scheme. Tree Physiology, $35,563-573$.

Oishi, A.C., Oren, R., Stoy, P.C., 2008. Estimating components of forest evapotranspiration: a footprint approach for scaling sap flux measurements. Agricultural and Forest Meteorology, 148, 1719-1732.

Phillips, N., Oren, R., Zimmermann, R., 1996. Radial patterns of xylem sap flow in non-, diffuse- and ring-porous tree species. Plant, Cell \& Environment, 19, 983-990.

Priestley, C.H.B., Taylor, R.J., 1972. On the assessment of surface heat flux and evaporation using large-scale parameters. Monthly Weather Review, 100, 81-92.

Qiu, J., 2009. Where the rubber meets the garden. Nature, 457, 246-247.

R Development Core Team, 2016. R: a language and environment for statistical computing. $\mathrm{R}$ Foundation for Statistical Computing, Vienna, Austria.

Röll, A., Niu, F., Meijide, A., Hardanto, A., Knohl, A., Hölscher, D., 2015. Transpiration in an oil palm landscape: effects of palm age. Biogeosciences, 12, 5619-5633.

Schlesinger, W.H., Jasechko, S., 2014. Transpiration in the global water cycle. Agricultural and Forest Meteorology, 189, 115-117.

Sopharat, J., Gay, F., Thaler, P., Sdoodee, S., Isarangkool Na Ayutthaya, S., Tanavud, C., Hammecker, C., Do, F.C., 2014. A simple framework to analyze water constraints on seasonal transpiration in rubber tree (Hevea brasiliensis) plantations. Frontiers in Plant Science, 5, 753.

Tan, Z.H., Zhang, Y.P., Song, Q.H., Liu, W.J., Deng, X.B., Tang, J.W., Deng, Y., Zhou, W.J., Yang, L.Y., Yu, G.R., et al., 2011. Rubber plantations act as water pumps in tropical China. Geophysical Research Letters, 38, L24406.

Van Noordwijk, M., Tata, H.L., Xu, J., Dewi, S., Minang, P.A., 2012. Segregate or integrate for multifunctionality and sustained change through rubber-based agroforestry in Indonesia and China. In Agroforestry-The Future of Global Land Use (69-104). Springer Netherlands.

Zang, D.Q., C.L. Beadle, D.A. White., 1996. Variation of sapflow velocity in Eucalyptus globules with position in sapwood and use of a correction coefficient. Tree Physiology, 16, 697-703.

Ziegler, A.D., Fox, J.M., Xu, J., 2009. The rubber juggernaut. Science, 324, 1024-1025. 
Table 5.1 Geography and climate, and stand characteristics in the studies from the Asian mainland and this study on Sumatra.

\begin{tabular}{|c|c|c|c|c|c|c|}
\hline & $\begin{array}{l}\text { Northeast } \\
\text { Thailand }^{\text {a,b }}\end{array}$ & $\begin{array}{l}\text { Northeast } \\
\text { Thailand }^{\mathrm{c}, \mathrm{d}}\end{array}$ & Cambodia ${ }^{\mathrm{c}, \mathrm{d}, \mathrm{e}}$ & Southern China $^{f}$ & Sumatra (all plots) ${ }^{\mathrm{g}}$ & Sumatra $(\text { BR3 })^{\mathrm{h}}$ \\
\hline \multicolumn{7}{|l|}{ Geography and Climate } \\
\hline Coordinates & $15^{\circ} 16^{\prime} \mathrm{N} 103^{\circ} 04^{\prime} \mathrm{E}$ & $18^{\circ} 12^{\prime} \mathrm{N} 103^{\circ} 25^{\prime} \mathrm{E}$ & $11^{\circ} 57^{\prime} \mathrm{N} 105^{\circ} 34^{\prime} \mathrm{E}$ & $21^{\circ} 55^{\prime} \mathrm{N} 101^{\circ} 15^{\prime} \mathrm{E}$ & $02^{\circ} 05^{\prime} \mathrm{S} 102^{\circ} 46^{\prime} \mathrm{E}$ & $02^{\circ} 05^{\prime} \mathrm{S} 102^{\circ} 46^{\prime} \mathrm{E}$ \\
\hline Elevation $(\mathrm{m})$ & NA & 210 & 57 & $550-680$ & $78 \pm 15$ & 90 \\
\hline Soil moisture $\left(\mathrm{m}^{3} \mathrm{~m}^{-3}\right)$ & $\sim 0.1-0.25$ & $\sim 0.1-0.3$ & $\sim 0.2-0.4$ & NA & $\sim 0.32-0.4$ & $0.32-0.4$ \\
\hline Mean annual rainfall (mm) & 1176 & $2118^{\#}$ & $1439^{\#}$ & 1487 & $1971^{\#}$ & $1971^{\#}$ \\
\hline $\begin{array}{l}\text { Length of dry season } \\
\left(<100 \mathrm{~mm} \mathrm{mo}^{-1}\right)(\mathrm{mo})\end{array}$ & 6 & 7 & 6 & 6 & 0 & 0 \\
\hline \multicolumn{7}{|l|}{ Radiation $\left(\mathrm{MJ} \mathrm{m}^{-2} \mathrm{yr}^{-1}\right)$} \\
\hline Annual & NA & $\sim 6500^{1}$ & $\sim 6800^{1}$ & NA & $5478^{\S}$ & $5478^{\S}$ \\
\hline Monthly min & & $\sim 460^{1}$ & $\sim 480^{1}$ & & $379^{\S}$ & $379^{\S}$ \\
\hline Monthly max & & $\sim 640^{1}$ & $\sim 640^{1}$ & & $530^{\S}$ & $530^{\S}$ \\
\hline \multicolumn{7}{|l|}{ Air temperature } \\
\hline Mean annual & NA & 26.1 & 26.5 & 21.5 & 26.7 & 26.7 \\
\hline Monthly min & & $14-15$ & $22-24$ & & 26 & 26 \\
\hline Monthly max & & $31-33$ & $30-32$ & & 28 & 28 \\
\hline \multicolumn{7}{|l|}{ Air humidity } \\
\hline Mean annual & NA & NA & $\sim 84 \%$ & $87 \%$ & $87 \%$ & $87 \%$ \\
\hline Monthly min & & & & & $91 \%$ & $91 \%$ \\
\hline Monthly max & & & & & $85 \%$ & $85 \%$ \\
\hline Potential evapotranspiration $\left(\mathrm{mm} \mathrm{yr}^{-1}\right)$ & $1247^{*}$ & $\sim 1600^{\dagger}$ & $\sim 1900^{\dagger}$ & $1000-1200^{\ddagger}$ & $1150 \pm 10^{*}$ & $1150 \pm 10^{*}$ \\
\hline \multicolumn{7}{|l|}{ Stand characteristics } \\
\hline Stand age $(y r)$ & 11 & 18 & 7 & 33 & $7-16$ & 7 \\
\hline Stand density (tree/ha) & 571 & 567 & 555 & NA & $502 \pm 147$ & 464 \\
\hline \multicolumn{7}{|l|}{ Leaf phenology } \\
\hline Degree of defoliation & Up to $100 \%$, & Up to $100 \%$, & Up to $100 \%$, & NA & $46 \%$ Partially & $40-70 \%$ defoliated, three \\
\hline Length of leaf-shedding period & 2 months & 1 month & 1 month & 2 months & defoliated & months \\
\hline Understory & NA & Sparse & Abundant & NA & Sparse & Sparse \\
\hline \multicolumn{7}{|l|}{ (Evapo)transpiration } \\
\hline${ }^{*}$ Transpiration $\left(\mathrm{mm} \mathrm{yr}^{-1}\right)$ & 430 & NA & 469,658 & NA & NA & 387 \\
\hline${ }^{\Delta}$ Evapotranspiration $\left(\mathrm{mm} \mathrm{yr}^{-1}\right)$ & NA & 1211 & 1459 & 1125 & NA & NA \\
\hline
\end{tabular}

${ }^{\mathrm{a}}$ Isarangkool Na Ayutthaya et al. (2011); ${ }^{\mathrm{b}}$ Sopharat et al. (2014); ${ }^{\mathrm{c}}$ Kumagai et al. (2015); ${ }^{\mathrm{d}}$ Giambelluca et al. (2016); ${ }^{\mathrm{e}}$ Kobayashi et al. (2014); ${ }^{\mathrm{f}}$ Tan et al. (2011);

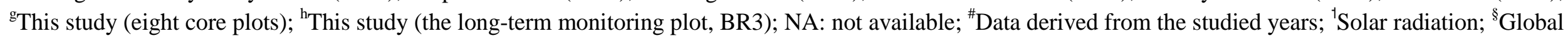
radiation; "The evapotranspiration was calculated according to the FAO 56 Penman-Monteith formula in Allen et al. (1998); ${ }^{\dagger}$ The potential evaporation was calculated according Priestley and Taylor, (1972); ${ }^{\ddagger}$ Class A pan evaporation; ${ }^{\#}$ Sap flux measurement; ${ }^{\Delta}$ Eddy covariance measurement. 
Appendix Table 5.1 Detailed stand characteristics and transpiration rates $(T)$ in the 10 rubber plantations studied in Jambi, Indonesia.

\begin{tabular}{|c|c|c|c|c|c|c|c|c|c|c|c|c|}
\hline $\begin{array}{l}\text { Plot } \\
\text { code }\end{array}$ & Coordinates & $\begin{array}{l}\text { Elevation } \\
\text { (m) }\end{array}$ & $\begin{array}{c}\text { Stand } \\
\text { density } \\
\text { (tree/ha) }\end{array}$ & $\begin{array}{c}\text { Average } \\
\text { diameter } \\
(\mathrm{cm})\end{array}$ & $\begin{array}{c}\text { Average } \\
\text { height } \\
\text { (m) }\end{array}$ & $\begin{array}{l}\text { Age } \\
(\mathrm{yr})\end{array}$ & $\begin{array}{l}\text { Measurement } \\
\text { period }\end{array}$ & $\begin{array}{c}* \text { Leaf } \\
\text { coverage }\end{array}$ & $\begin{array}{c}\text { T_leaf- } \\
\text { shedding } \\
\left(\mathbf{m m ~ d}^{-1}\right)\end{array}$ & $\begin{array}{c}\text { T_fully-leaved } \\
\left(\mathbf{m m ~ d}^{-1}\right)\end{array}$ & $\begin{array}{c}\text { Daily average } \\
\text { VPD } \\
(\mathbf{k P a})\end{array}$ & 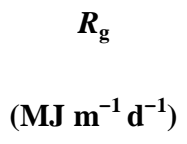 \\
\hline BR1 & $\begin{array}{c}2^{\circ} 5.51^{\prime} \mathrm{S} \\
102^{\circ} 48.51^{\prime} \mathrm{E}\end{array}$ & 71 & 552 & $16.94 \pm 4.79$ & $13.39 \pm 2.65$ & 16 & $25.4-15.5 .13$ & no & NA & $1.28 \pm 0.11$ & $0.73 \pm 0.12$ & $20.88 \pm 1.51$ \\
\hline BR2 & $\begin{array}{c}2^{\circ} 5.11^{\prime} \mathrm{S} \\
102^{\circ} 47.35^{\prime} \mathrm{E}\end{array}$ & 95 & 556 & $13.96 \pm 1.98$ & $13.46 \pm 1.17$ & 8 & $8.2-8.3 .13$ & no & NA & $1.37 \pm 0.19$ & $0.93 \pm 0.29$ & $20.46 \pm 1.38$ \\
\hline BR3 & $\begin{array}{c}2^{\circ} 5.72^{\prime} \mathrm{S} \\
102^{\circ} 46.99^{\prime} \mathrm{E}\end{array}$ & 90 & 464 & $14.46 \pm 2.04$ & $13.18 \pm 1.35$ & 7 & $13.6 .13-22.1 .14$ & $* * 30-60 \%$ & $1.02 \pm 0.09$ & $1.37 \pm 0.14$ & $\begin{array}{l}1.15 \pm 0.24^{*} \\
0.77 \pm 0.14^{\dagger}\end{array}$ & $\begin{array}{l}22.37 \pm 0.62^{\ddagger} \\
21.10 \pm 0.09^{\dagger}\end{array}$ \\
\hline BR4 & $\begin{array}{c}2^{\circ} 4.60^{\prime} \mathrm{S} \\
102^{\circ} 46.37^{\prime} \mathrm{E}\end{array}$ & 51 & 484 & $15.43 \pm 2.90$ & $13.71 \pm 1.76$ & 8 & $12.3-16.4 .13$ & no & NA & $1.35 \pm 0.16$ & $0.76 \pm 0.08$ & $22.97 \pm 0.46$ \\
\hline HR1 & $\begin{array}{c}1^{\circ} 54.66^{\prime} \mathrm{S} \\
103^{\circ} 16.00^{\prime} \mathrm{E}\end{array}$ & 77 & 372 & $20.47 \pm 3.97$ & $14.41 \pm 1.72$ & 14 & $25.11 .13-4.1 .14$ & no & NA & $1.00 \pm 0.10$ & $0.71 \pm 0.10$ & $19.17 \pm 0.95$ \\
\hline HR2 & $\begin{array}{c}1^{\circ} 52.74^{\prime} \mathrm{S} \\
103^{\circ} 16.47^{\prime} \mathrm{E}\end{array}$ & 59 & 300 & $18.48 \pm 4.02$ & $13.89 \pm 2.22$ & 15 & $27.7-2.9 .13$ & $60 \%$ & $0.77 \pm 0.23$ & NA & $0.99 \pm 0.11$ & $21.31 \pm 1.11$ \\
\hline HR3 & $\begin{array}{c}1^{\circ} 51.58^{\prime} \mathrm{S} \\
103^{\circ} 18.04^{\prime} \mathrm{E}\end{array}$ & 90 & 448 & $17.62 \pm 5.19$ & $12.96 \pm 2.62$ & 17 & 4.9-23.9.13 & $60-70 \%$ & $0.87 \pm 0.11$ & NA & $0.88 \pm 0.10$ & $22.30 \pm 0.64$ \\
\hline HR4 & $\begin{array}{c}1^{\circ} 48.30^{\prime} \mathrm{S} \\
103^{\circ} 15.87^{\prime} \mathrm{E}\end{array}$ & 71 & 820 & $14.49 \pm 4.59$ & $12.43 \pm 2.49$ & 15 & $31.5-23.7 .13$ & $40-50 \%$ & $0.98 \pm 0.19$ & NA & $0.88 \pm 0.62$ & $18.83 \pm 1.68$ \\
\hline YR 1 & $\begin{array}{c}2^{\circ} 5.72^{\prime} \mathrm{S} \\
102^{\circ} 46.99^{\prime} \mathrm{E}\end{array}$ & 90 & 400 & $5.1 \pm 1.1$ & $4.91 \pm 1.11$ & 2 & $12.11-30.12 .13$ & no & NA & $0.14 \pm 0.02$ & $0.83 \pm 0.14$ & $20.99 \pm 0.29$ \\
\hline YR 2 & $\begin{array}{c}2^{\circ} 5.72^{\prime} \mathrm{S} \\
102^{\circ} 46.99^{\prime} \mathrm{E}\end{array}$ & 90 & 625 & $12.25 \pm 1.23$ & $8.00 \pm 0.41$ & 5 & $14.01-2.03 .14$ & no & NA & $0.84 \pm 0.17$ & $0.64 \pm 0.04$ & $15.14 \pm 1.69$ \\
\hline
\end{tabular}

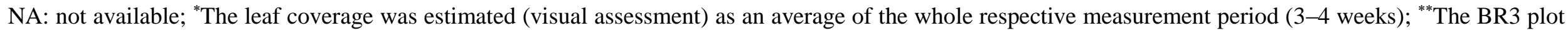

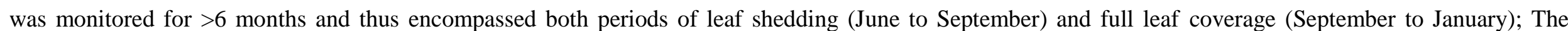

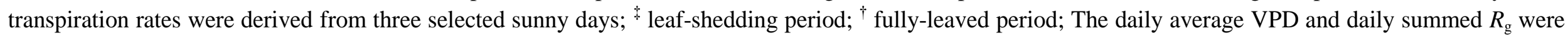
derived from respective three sunny days. 
CHAPTER 6

\section{SYNTHESIS}




\subsection{Overview}

The drastic recent conversion of natural rainforest to rubber and oil palm plantations in Indonesia could potentially affect the local hydrological cycle. Transpiration as a key process of the water cycle had previously only scarcely been studied for the two plantation types, particularly in maritime Indonesia (Carr, 2011; Comte et al., 2012). This study aimed at estimating plant water use and stand transpiration rates of mono-cultural oil palm and rubber plantations in Indonesia by conducting sap flux measurements. We established and refined a commonly applied sap flux measurement technique on both species and derived reliable field measurement schemes. Subsequently, extensive field measurements were carried out in 15 oil palm and 10 rubber plantations in order to delineate differences in water use characteristics between the two species, particularly with regard to the magnitude of water fluxes, the water use responses to fluctuations in key environmental drivers and the variability of water use across space and time.

\subsection{Establishing and refining the method}

The thermal dissipation probe (TDP; Granier, 1985) technique has been widely applied for studying whole plant water use (Smith and Allen, 1996; Wullschleger et al., 1998; Lu et al., 2004). As this method is associated with estimation uncertainties due to the empirical nature of its calibration equation, it is suggested to re-calibrate/validate the method when applying it to a previously unstudied species (Wullschleger et al., 1998; Clearwater et al., 1999; McCulloh et al., 2007; Bush et al., 2010). We consequently conducted laboratory calibration experiments for TDP measurements on both species. For monocot oil palms, our calibration experiment indicated a $17.3 \%$ overestimation when using the original calibration equation (see Figure 3.3); we thus derived new, species-specific parameters for TDP measurements on oil palm leaf petioles. For dicot rubber trees, an overestimation of sap flux density of only $4 \%$ was observed when using the original equation (see Figure 5.2). We thus decided that the original calibration equation is applicable for TDP measurements on rubber trees.

Besides from a potentially biased calibration equation, the scaling up from TDP point measurement to whole plant and subsequently stand level water use is another error source of TDP measurements (Nadezhdina et al., 1998; Oishi et al., 2008; Berdanier et al., 2016). To derive an appropriate scheme, we installed TDP sensors in our oil palm long-term monitoring plot in different directions and at different leaf positions to assess the influence of leaf traits on leaf level water use. Our results indicate that there was no significant relationship between any of the assessed leaf traits and leaf water use. We thus decided to apply an un-stratified sampling scheme. Following Kume et al. (2010), we further assessed estimation uncertainties related to limited sample size, i.e. number of measured leaves. This allowed to derive so-called "optimal sample 
sizes", which were 13 leaves to determine average leaf water use and four palms to establish the average number of leaves per palm. Combined, this approach resulted in a relative standard error of mean stand transpiration of $14.2 \%$.

To derive an appropriate sampling scheme for TDP measurements on rubber trees, we applied heat field deformation (HFD; Nadezhdina et al., 1998) sensors on five rubber trees to assess radial changes of sap flux density $\left(J_{\mathrm{s}}\right)$ in tree trunks in our rubber long-term monitoring plot. We then scaled up the TDP point measurements to whole plant water use by using the HFD-derived radial profiles of $J_{\mathrm{s}}$. We further validated this combined TDP/HFD scheme with another independent sap flux technique (i.e. the stem heat balance method; Sakuratani, 1981), which confirmed that our measurements were reliable. In analogy to our work on oil palms, we assessed the potential estimation errors related to limited sample size in rubber trees. The results indicate a total relative standard error of tree water use rates of $15 \%$ when measuring $J_{\mathrm{s}}$ on six trees (i.e. with 12 TPD sensors) and when deriving the "effective sapwood area" on five trees, respectively.

\subsection{Differences in oil palm and rubber tree water use}

We compared diurnal changes of palm/tree water use on a single sunny and a single cloudy day. Under both sunny and cloudy conditions, the whole tree water use was much higher in oil palms than in rubber trees. Hourly water use rates drastically increased in the morning hours, reach their daily maxima relatively early (around $11 \mathrm{am}$ ) in both species. However, after this peak, water use consistently and substantially decreased in oil palms, while remaining relatively stable in rubber trees until the afternoon hours. Whole plant water use decreased considerably from sunny to cloudy conditions in both species; the absolute decline was larger in oil palms as compared to rubber trees (Figure 6.1). 

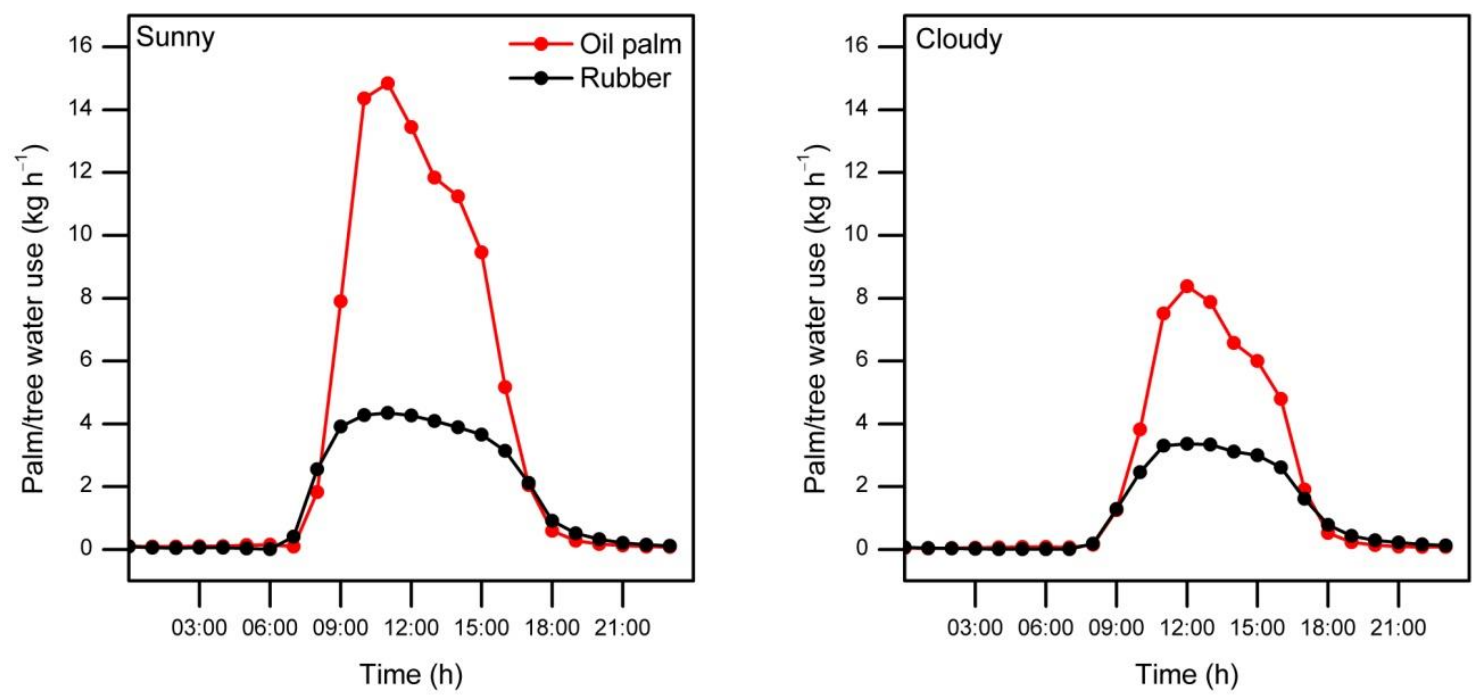

Figure 6.1 The diurnal courses of palm/tree water use in the oil palm and rubber long-term monitoring plots (BO3 and BR3). Points represent hourly average values. Data come from one typical sunny day (daytime average VPD $=1.65 \mathrm{kPa}$; daily summed radiation $=20.4 \mathrm{MJ} \mathrm{m}^{-2} \mathrm{~d}^{-1}$ ) and one cloudy day (daytime average $\mathrm{VPD}=0.55 \mathrm{kPa}$; daily summed radiation $=7.9 \mathrm{MJ} \mathrm{m}^{-2} \mathrm{~d}^{-1}$ ).

For further assessing the influences of environmental drivers on whole plant water use in the diurnal course, we plotted hourly averaged palm/tree water use against vapor pressure deficit (VPD) and radiation. Under sunny conditions, pronounced hystereses were observed in the relationship between palm/tree water use and VPD in both oil palm and rubber tree (Figure 6.2). In oil palms, the water use drastically increased with increasing VPD in the early morning, reaching its peak at $11 \mathrm{am}$, when VPD was at $65 \%$ of its daily maximum. Water use subsequently dropped sharply (to 64\% of its daily maximum) when VPD reached its diurnal peak. In rubber trees, the water use pattern was similar to oil palm in the morning, i.e. drastic increases with rising VPD, reaching the peak at 11 am when VPD was at $65 \%$ of its daily maximum. After that, however, rubber tree water use remained relatively stable (over $84 \%$ of its daily maximum) until maximum VPD was reached. Such hystereses in the relationships between water use and environment drivers have also been reported in several other studies (Kelliher et al., 1992; Meinzer et al., 1997; O'Grady et al., 1999, 2008; O'Brien et al., 2004; Zeppel et al., 2004). Their occurrence has been linked to several possible mechanisms: e.g., some studies reported that leaf stomatal conductance and net photosynthetic rates were higher in the morning comparing to the afternoon (Eamus and Cole, 1997; Fordyce et al., 1997; Prior et al., 1997), which could be driven by differences in stomatal sensitivity to VPD at varying times and which consequently result in non-proportional changes between VPD and water use in the diurnal course (Meinzer et al., 1997; O'Grady et al., 2008). However, for oil palms and rubber trees, data on stomatal sensitivity to VPD in the diurnal course are to our knowledge not available thus far. Other potential reasons for the observed hysteresis e.g. include declines in hydraulic conductance along the soil-to-canopy 
pathway (O’Grady et al., 1999; Zeppel et al., 2004). In our study region and during our study period, no pronounced dry season was observed, and soil moisture was never limiting for plant water use during the study period. Hence, the decline of hydraulic conductance is likely not the reason for the observed hysteresis. Internal water storage could also contribute to the occurrence of hysteresis (O'Grady et al., 1999), which is discussed in more detail for oil palms in Niu et al. (2015) (Chapter 3) and Röll et al. (2015) (Chapter 4). Under cloudy conditions, the hystereses of both species were considerably decreased; revealing that palm/tree water uses were coupled more closely to VPD under conditions of low-evaporative-demanded. In the same study region, more pronounced hysteresis was observed in the relation between water use and VPD in oil palm plantations compared to mean water use rate of three tree based land use types (i.e. natural rainforest, "jungle rubber" agricultural system, and rubber monoculture) versus VPD, under both sunny and cloudy conditions (Röll et al., in preparation). This may suggest that rubber and oil palm monocultures have different response patterns to fluctuations in VPD as compared to other tree species in the local natural rainforest.

At the day-to-day scale, stand transpiration rates were significantly correlated with VPD in both oil palm and rubber tree (full leaf coverage) plantations. Similar response patterns were observed in the oil palm and rubber long-term monitoring plots, i.e. stand transpiration rates increased with increasing VPD in the lower VPD range and tended to level-off when VPD was higher (Figure 6.3). Soil moisture was never limited in the study area throughout the measurement period; saturated transpiration rates under conditions of high-evaporative demand may thus be solely due to stomata closure, a mechanism which potentially protects xylem from catastrophic cavitation (David et al., 2004). Declines of stomatal conductance with increasing VPD have e.g. been reported for rubber plantations from mainland Southeast Asia (Kobayashi et al., 2014; Kumagai et al., 2015), which could thus also be the case for our maritime study region in Indonesia. For oil palm, the decreasing tendency of stomatal conductance at increasing VPD has further been confirmed for two of the studied plantations (Meijide et al., in review). 

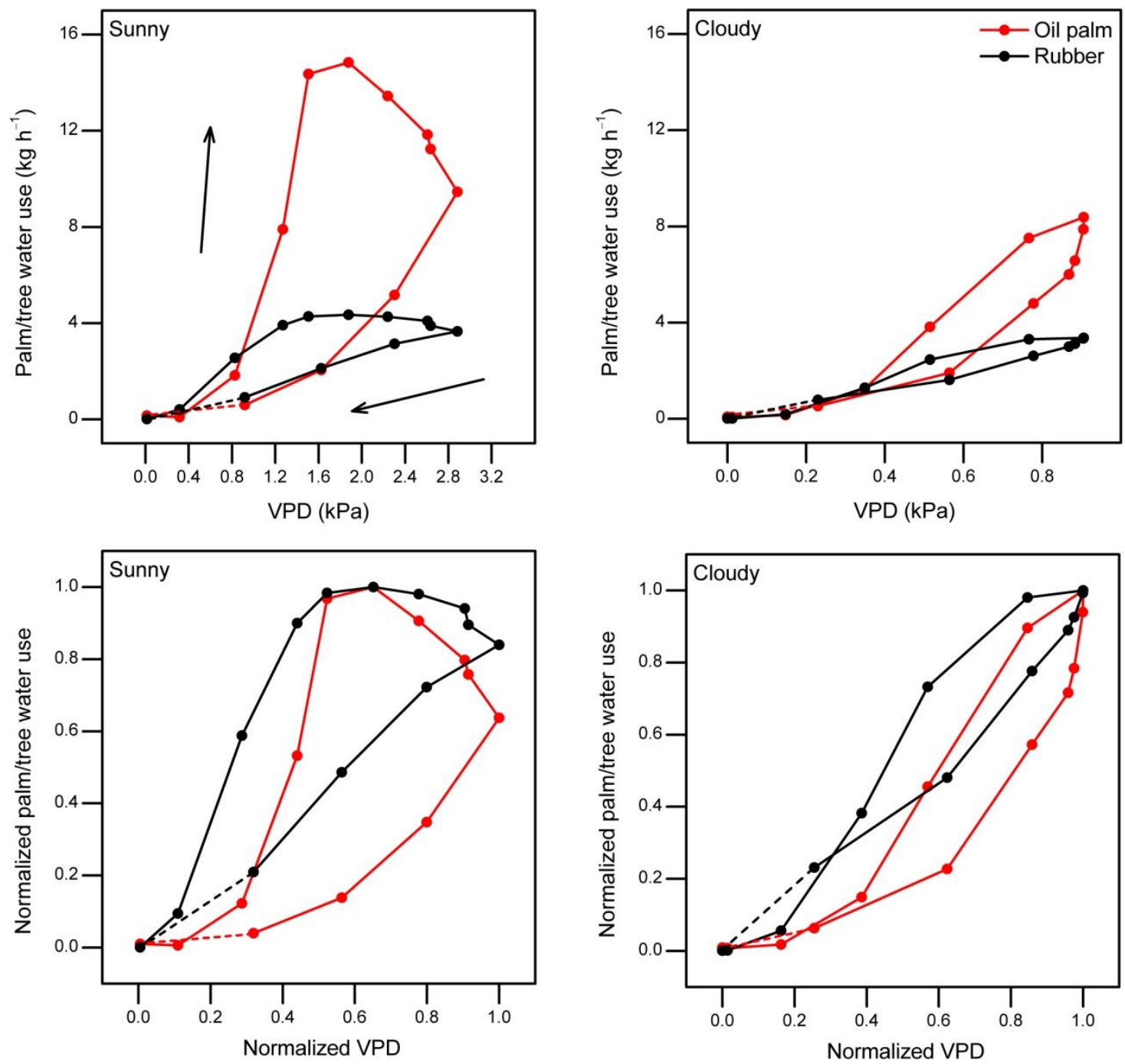

Figure 6.2 Palm/tree water use (both absolute and normalized values) plotted against vapor pressure deficit (VPD, absolute and normalized values) on one typical sunny day (daytime average $\mathrm{VPD}=1.65 \mathrm{kPa}$; daily summed radiation $=20.4 \mathrm{MJ} \mathrm{m}^{-2} \mathrm{~d}^{-1}$ ) and one cloudy day (daytime average VPD $=0.55 \mathrm{kPa}$; daily summed radiation $=7.9 \mathrm{MJ} \mathrm{m}^{-2} \mathrm{~d}^{-1}$ ). Data for rubber trees were from fully-leaved period. Points represent hourly averaged values. Arrows indicate the direction in which the next consecutive observation in time occurred. 


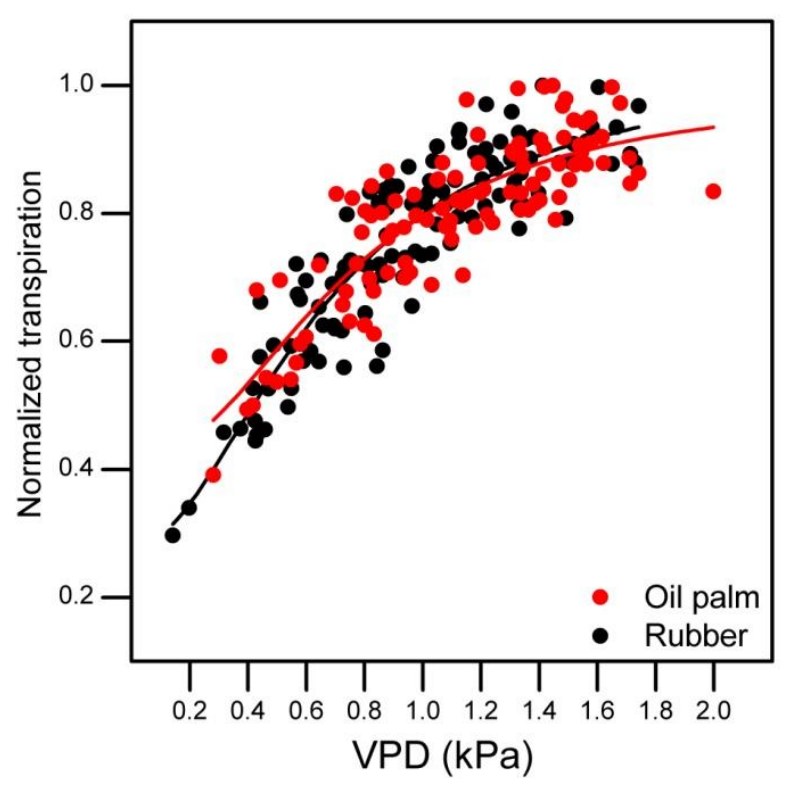

Figure 6.3 Normalized stand transpiration rates in the oil palm and rubber long-term monitoring plots (BO3 and BR3) plotted against VPD. Data for rubber plantations were from the fully-leaved period. Transpiration rates are daily averages, VPD data are daytime averages.

At the seasonal scale, there were pronounced differences in water use characteristics between oil palms and rubber trees due to partial leaf shedding in rubber trees during relatively dry periods, which reduced the transpiration of rubber plantations by up to $60 \%$ (Figure 6.4). Similar reductions due to leaf shedding were also reported for rubber plantations from mainland Southeast Asia, with around $50-75 \%$ decreases in transpiration/evapotranspiration rates during dry conditions, which tend to be more pronounced on the mainland (Kobayashi et al., 2014; Sopharat et al., 2014; Giambelluca et al., 2016). During relatively dry periods, rubber can thus sharply reduce transpiration by leaf shedding, while oil palm transpiration keeps stable, transpiring as much as under wet conditions. This can lead to substantial differences in the annual transpiration rate, which can affect local hydrological cycles. Excluding the dry periods and thus the periods of rubber leaf shedding, the transpiration rates of the two species were both closely correlated with environmental drivers (i.e. VPD and radiation). For both species, they were largely reduced on days with strong precipitation events (Figure 6.4). 


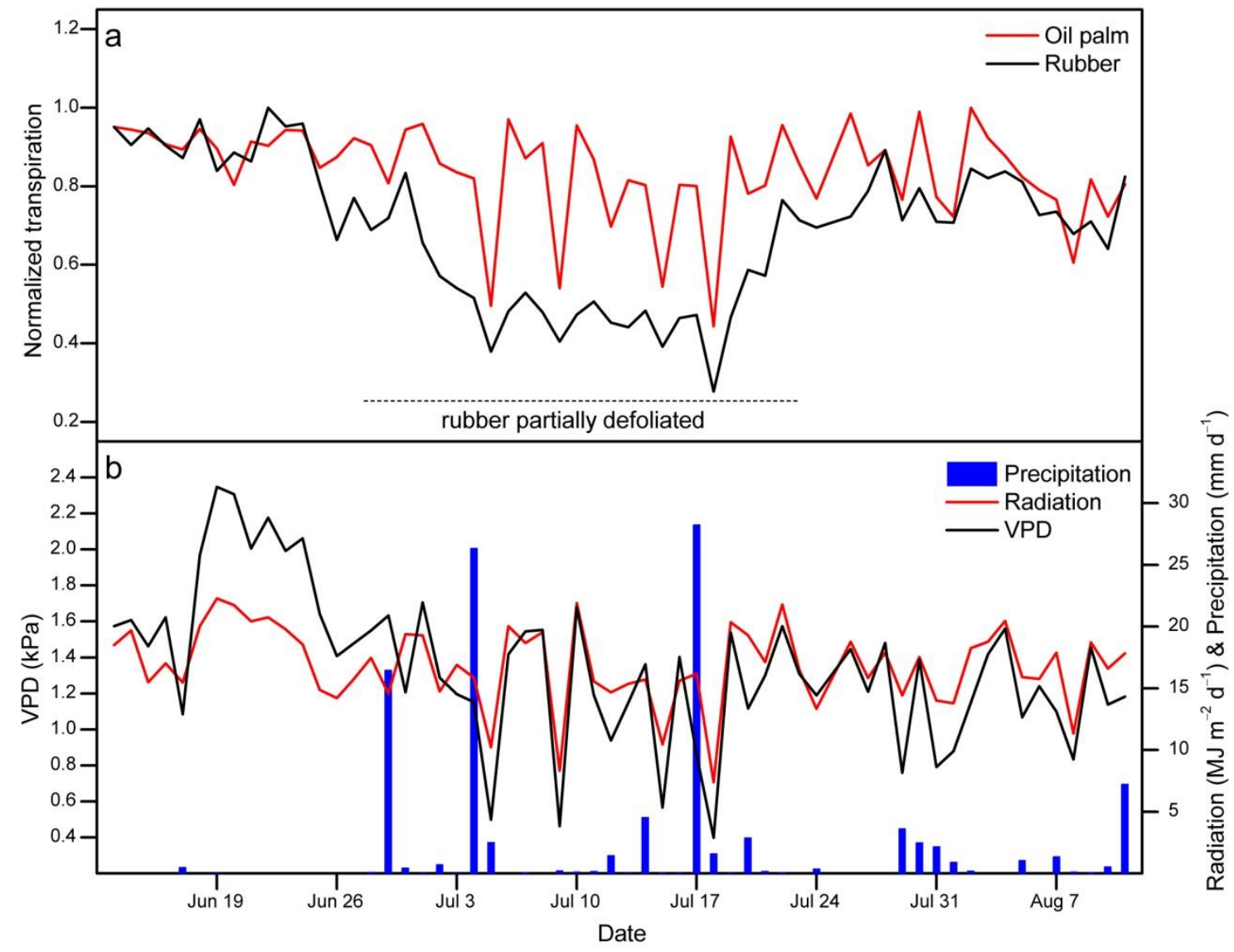

Figure 6.4 Seasonal changes of normalized transpiration (a) and VPD, radiation and precipitation (b) in the oil palm and rubber long-term monitoring plots (BO3 and BR3). Data from 13 June to 10 August 2013. Transpiration rates were normalized by setting the respective maxima during the study periods to one. VPD data are daytime averages, radiation data are presented as daysums.

The age effects on palm/tree water use and stand transpiration were studied at 15 on-farm plots in oil palm, which ranged from 2 to 25 years old, and at 10 on-farm plots in rubber, which ranged from 2 to 17 years old. We found significant age effects on whole plant water use and stand transpiration for both species (Figure 6.5). In oil palm plantations, palm water use/stand transpiration increased drastically from two to eight-year old plantations, and large variability was observed among medium aged ones (10 to 18-year old), followed by a slightly decrease in old plantations (25-years old). The highest stand transpiration rate $\left(2.5 \mathrm{~mm} \mathrm{~d}^{-1}\right)$ occurred in a commercial oil palm company with more intensive management; it was comparable or even higher than rates reported for natural rainforests (Röll et al., in preparation). Similar to oil palm plantations, tree water use and stand transpiration in rubber plantations quickly increased from two to seven-year old plantations and then level-off in older ones. Stand age can thus largely explain spatial variability of whole plant water use (59-71\%) and stand transpiration rate (59$61 \%$ ) in both oil palm and rubber plantations (Figure 6.5). Under sunny conditions, the average 
transpiration rate of mature oil palm stands was around $30 \%$ higher $\left(1.61 \mathrm{~mm} \mathrm{~d}^{-1}\right)$ than in mature rubber plantations $\left(1.27 \mathrm{~mm} \mathrm{~d}^{-1}\right)$.
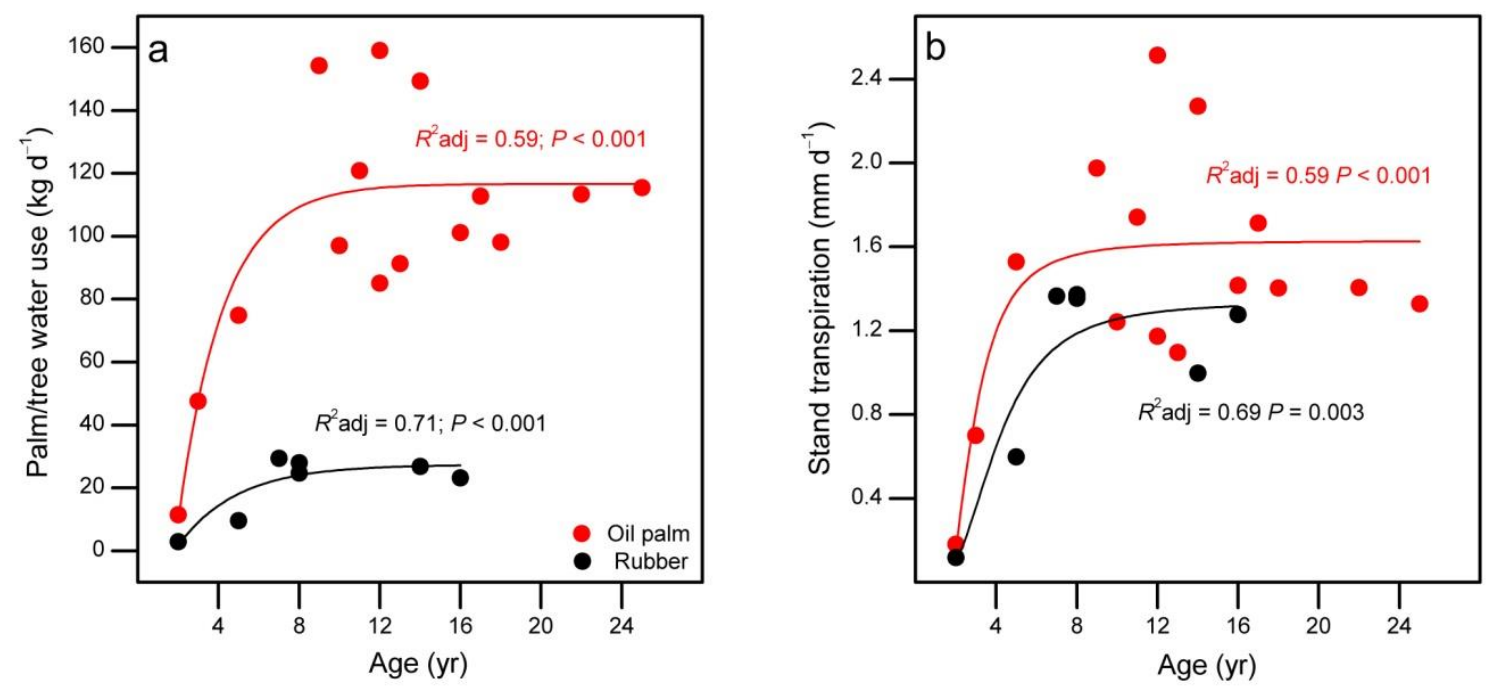

Figure 6.5 The palm/tree water use (a) and stand transpiration (b) plotted against stand ages in oil palm and rubber plantations. The presented data are averages of three sunny days. Data for rubber plantations are all from fully-leaved periods.

The differences of transpiration rates between oil palm and rubber monocultures with regard to the magnitude of water fluxes, their seasonal variability and the spatial heterogeneity induced by varying plantation age provide first insights into water use characteristics of the still expanding oil palm and rubber monocultures in maritime Indonesia. They contribute to allow for an assessment of the potential eco-hydrological consequences of agricultural expansion on the local water cycle, which is often at the cost of remaining natural forests. E.g., concerns regarding periodical water scarcity in oil palm dominated areas have recently been raised based on a study assessing social aspects and natural science measurements of (evapo)transpiration, soil hydrologic characteristics including estimated erosion of topsoil and catchment stream-flow characteristics (Merten et al., 2016). Even though our study reported much lower transpiration rates in rubber plantations than in oil palm plantations, rubber plantation may also be problematic hydrologically when including soil hydrological characteristics such as erosion into the analysis; this will have to be assessed in more detail in further eco-hydrological studies. 


\section{References}

Berdanier, A.B., Miniat, C.F., Clark, J.S., 2016. Predictive models for radial sap flux variation in coniferous, diffuse-porous and ring-porous temperate trees. Tree Physiology, tpw027.

Bush, S.E., Hultine, K.R., Sperry, J.S., Ehleringer, J.R., 2010. Calibration of thermal dissipation sap flow probes for ring-and diffuse-porous trees. Tree Physiology, 30, 1545-1554.

Carr, M.K.V., 2011. The water relations and irrigation requirements of oil palm (Elaeis guineensis): a review. Experimental Agriculture, 47, 629-652.

Clearwater, M.J., Meinzer, F.C., Andrade, J.L., Goldstein, G., Holbrook, N.M., 1999. Potential errors in measurement of nonuniform sap flow using heat dissipation probes. Tree Physiology, 19, 681-687.

Comte, I., Colin, F., Whalen, J. K., Grünberger, O., Caliman, J. P., 2012. Agricultural practices in oil palm plantations and their impact on hydrological changes, nutrient fluxes and water quality in Indonesia. Advances in Agronomy, 116, 71-124.

David, T.S., Ferreira, M.I., Cohen, S., Pereira, J.S., David, J.S., 2004. Constraints on transpiration from an evergreen oak tree in southern Portugal. Agricultural and Forest Meteorology, $122,193-205$.

Eamus, D., Cole, S., 1997. Diurnal and seasonal comparisons of assimilation, phyllode conductance and water potential of three Acacia and one Eucalyptus species in the wetdry tropics of Australia. Australian Journal of Botany, 45, 275-290.

Fordyce, I.R., Duff, G.A., Eamus, D., 1997. The water relations of Allosyncarpia ternata (Myrtaceae) at contrasting sites in the monsoonal tropics of northern Australia. Australian Journal of Botany, 45, 259-274.

Giambelluca, T.W., Mudd, R.G., Liu, W., Ziegler, A.D., Kobayashi, N., Kumagai, T.O., Miyazawa, Y., Lim, T.K., Huang, M., Fox, J., et al., 2016. Evapotranspiration of rubber (Hevea brasiliensis) cultivated at two plantation sites in Southeast Asia. Water Resources Research, 52, 660-679.

Granier, A., 1985. Une nouvelle méthode pour la mesure du flux de sève brute dans le tronc des arbres. Annals of Forest Science, 42, 193-200.

Kelliher, F.M., Köstner, B.M.M., Hollinger, D.Y., Byers, J.N., Hunt, J.E., McSeveny, T.M., Meserth, R., Weir, P.L., Schulze, E.D., 1992. Evaporation, xylem sap flow, and tree transpiration in a New Zealand broad-leaved forest. Agricultural and Forest Meteorology, $62,53-73$.

Kobayashi, N., Kumagai, T.O., Miyazawa, Y., Matsumoto, K., Tateishi, M., Lim, T.K., Mudd, R.G., Ziegler, A.D., Giambelluca, T.W., Yin, S., 2014. Transpiration characteristics of a rubber plantation in central Cambodia. Tree Physiology, 34, 285-301.

Kumagai, T.O., Mudd, R.G., Giambelluca, T.W., Kobayashi, N., Miyazawa, Y., Lim, T.K., Liu, W., Huang, M., Fox, J.M., Ziegler, A.D., et al., 2015. How do rubber (Hevea brasiliensis) plantations behave under seasonal water stress in northeastern Thailand and central Cambodia? Agricultural and Forest Meteorology, 213, 10-22.

Kume, T., Onozawa, Y., Komatsu, H., Tsuruta, K., Shinohara, Y., Umebayashi, T., Otsuki, K., 2010. Stand-scale transpiration estimates in a Moso bamboo forest: (I) Applicability of sap flux measurements. Forest Ecology and Management, 260, 1287-1294.

Lu, P., Urban, L. and Zhao, P., 2004. Granier's thermal dissipation probe (TDP) method for measuring sap flow in trees: theory and practice. Acta Botanica Sinica, 46, 631-646. 
McCulloh, K.A., Winter, K., Meinzer, F.C., Garcia, M., Aranda, J., Lachenbruch, B., 2007. A comparison of daily water use estimates derived from constant-heat sap-flow probe values and gravimetric measurements in pot-grown saplings. Tree Physiology, 27, 1355-1360.

Meijide, A., Röll, A., Fan, Y., Herbst, M., Niu, F., Tiedemann, F., June, T., Rauf, A., Hölscher, D., Knohl, A. Controls of water and energy fluxes in oil palm plantations: effect of environmental variables and oil palm age. In review.

Meinzer, F.C., Hinckley, T.M., Ceulemans, R., 1997. Apparent responses of stomata to transpiration and humidity in a hybrid poplar canopy. Plant, Cell \& Environment, 20, 1301-1308.

Merten, J., Röll, A., Guillaume, T., Meijide, A., Tarigan, S., Agusta, H., Dislich, C., Dittrich, C., Faust, H., Gunawan, D., et al., 2016. Water scarcity and oil palm expansion: social views and environmental processes. Ecology and Society, 21, 5

Nadezhdina, N., Cermák, J., Nadezhdin, V., 1998. Heat field deformation method for sap flow measurements. In: Cermák, J., Nadezhdina, N. (Eds.), Proceedings of the 4th International Workshop on Measuring Sap Flow in Intact Plants. Publishing House of Mendel University, Czech Republic, 72-92

Niu, F., Röll, A., Hardanto, A., Meijide, A., Köhler, M., Hendrayanto, Hölscher, D., 2015. Oil palm water use: calibration of a sap flux method and a field measurement scheme. Tree Physiology, 35, 563-573.

O'Brien, J.J., Oberbauer, S.F., Clark, D.B., 2004. Whole tree xylem sap flow responses to multiple environmental variables in a wet tropical forest. Plant, Cell \& Environment, 27, 551-567.

O'Grady, A.P., Eamus, D., Hutley, L.B., 1999. Transpiration increases during the dry season: patterns of tree water use in eucalypt open-forests of northern Australia. Tree Physiology, 19, 591-597.

O'Grady, A.P., Worledge, D., Battaglia, M., 2008. Constraints on transpiration of Eucalyptus globulus in southern Tasmania, Australia. Agricultural and Forest Meteorology, 148, 453-465.

Oishi, A.C., Oren, R., Stoy, P.C., 2008. Estimating components of forest evapotranspiration: a footprint approach for scaling sap flux measurements. Agricultural and Forest Meteorology, 148, 1719-1732.

Prior, L.D., Eamus, D., Duff, G.A., 1997. Seasonal trends in carbon assimilation, stomatal conductance, pre-dawn leaf water potential and growth in Terminalia ferdinandiana, a deciduous tree of northern Australian savannas. Australian Journal of Botany, 45, 53-69.

Röll, A., Niu, F., Meijide, A., Hardanto, A., Hendrayanto, Knohl, A., Hölscher, D. Transpiration changes after rainforests transformation to rubber and oil palm plantations. In prepration

Röll, A., Niu, F., Meijide, A., Hardanto, A., Hendrayanto, Knohl, A., Hölscher, D., 2015. Transpiration in an oil palm landscape: effects of palm age. Biogeosciences, 12, 56195633.

Sakuratani, T., 1981. A heat balance method for measuring water flux in the stem of intact plants. Journal of Agricultural Meteorology, 37, 9-17.

Smith, D.M., Allen, S.J., 1996. Measurement of sap flow in plant stems. Journal of Experimental Botany, 47, 1833-1844.

Sopharat, J., Gay, F., Thaler, P., Sdoodee, S., Isarangkool Na Ayutthaya, S., Tanavud, C., Hammecker, C., Do, F.C., 2014. A simple framework to analyze water constraints on 
seasonal transpiration in rubber tree (Hevea brasiliensis) plantations. Frontiers in Plant Science, 5, 753 .

Wullschleger, S.D., Meinzer, F.C., Vertessy, R.A., 1998. A review of whole-plant water use studies in tree. Tree Physiology, 18, 499-512.

Zeppel, M.J., Murray, B.R., Barton, C., Eamus, D., 2004. Seasonal responses of xylem sap velocity to VPD and solar radiation during drought in a stand of native trees in temperate Australia. Functional Plant Biology, 31, 461-470. 


\section{INDEX OF FIGURES}

Figure 1.1 The cultivated area (a) and production (b) of oil palm plantations in Indonesia, Pg. Malaysia, and the world from 1990 to 2014. Data are from FAOSTAT (2016). 3

Figure 1.2 Distribution of oil palm and rubber plantations in Indonesia. Data from 5 "Transparent World-Tree Plantations" and "Indonesia Ministry of Forestry", both accessed through "Global Forest Watch (www.globalforestwatch.org)".

Figure 2.1 Locations of the studied plots in Jambi province, Sumatra, Indonesia.

Figure 2.2 Field installation of TDP sensors on oil palm in the long-term monitoring plot.

Figure 2.3 Field installations of TDP measurements on rubber tree in the long-term monitoring rubber plot.

Figure 2.4 Parallel sap flux and eddy covariance measurements in a young oil palm plantation.

Figure 3.1 Experimental set-up for the comparison of thermal dissipation probe (TDP) measurements with gravimetric readings on oil palm petioles (calibration experiment).

Figure 3.2 Cross-section of an oil palm petiole at location of probe installation (a) and installation of thermal dissipation probes (TDP) on oil palms in the field (b).

Figure 3.3 Sap flux densities derived from gravimetric measurements $\left(J_{\mathrm{g}}\right)$ and thermal dissipation probes $\left(J_{\mathrm{s}}\right)$ using the original parameters of the calibration equation (a) and our newly-derived parameters (b). Pooled data from eight oil palm segments, points represent 10-minute-averages, regression lines (solid lines) were forced through the origin, dashed lines indicate a 1:1 relationship.

Figure 3.4 Relative standard error of the mean $\left(\mathrm{SE}_{\mathrm{n}}\right)$ of average leaf water use $\left(E_{\mathrm{L}}\right)$ (a) and of the average number of leaves per palm $\left(N_{\mathrm{L}}\right)$ (b) in dependence of sample size, the number of measured leaves $(n)$ and sampled palms $(m)$, respectively. The dotted lines indicate "optimal" sample sizes, at which $\frac{\mathrm{dSE}_{\mathrm{n}}}{\mathrm{d} n, \mathrm{~d} m}>-0.005$.

Figure 3.5 Average leaf water use $\left(E_{\mathrm{L}}\right)$ plotted against average daytime vapor pressure deficit (VPD) (a) and integrated daily radiation $\left(R_{\mathrm{g}}\right)(\mathrm{b})$. Data of 90 days, $E_{\mathrm{L}}$ estimates based on at least 13 leaves measured simultaneously.

Figure 3.6 The diurnal courses of vapor pressure deficit (VPD) and radiation $\left(R_{\mathrm{g}}\right)$ (a) and of average leaf water use $\left(E_{\mathrm{L}}\right)(\mathrm{b})$. Normalized $E_{\mathrm{L}}$ plotted against normalized VPD (c) and normalized $R_{\mathrm{g}}(\mathrm{d})$. The points represent hourly means of three sunny days; the arrows indicate the direction in which the next consecutive observation in time occurred. $E_{\mathrm{L}}$ estimates based on at least 13 leaves measured 
simultaneously.

Figure 4.1 Locations of the studied oil palm stands in Jambi province, Sumatra, Indonesia. 47

Figure 4.2 The change of stand density (a), average number of leaves per palm (b), 52 average trunk height (c), and stand water conductive area (d) over age in the 15 studied oil palm stands.

Figure 4.3 The change of maximum hourly sap flux density (a), average leaf water use 54 (b), average palm water use (c) and stand transpiration (d) over stand age. Data of the different levels derived from simultaneous sap flux measurements on at least 13 leaves per stand; values of three sunny days averaged.

Figure 4.4 Diurnal course of vapor pressure deficit (VPD) and radiation $\left(R_{\mathrm{g}}\right)$ (a) and of sap flux density in four oil palm stands (b). Leaf water use plotted against hourly averages of normalized VPD (c) and Rg (d). Average water use estimates based on at least 13 leaves measured simultaneously; average water use rates, VPD and radiation of three sunny days, each point represents one hourly observation. Data are from the locations PA (2 years old, black arrows), BO3 (12 years old, low water use, red arrows), PTPN6 (12 years old, high water use, blue arrows) and HAR_old (25 years old, green arrows). Data were normalized by setting the maximum to one.

Figure 4.5 The day-to-day response of leaf water use rates in four different oil palm stands to changes in average daytime vapor pressure deficit (VPD) (a) and integrated daily radiation $\left(R_{\mathrm{g}}\right)(\mathrm{b})$ taken from the closest micrometeorological station from the respective plots. Data of at least 20 days per plot, each point represents one day. Leaf water use rates are from the locations PA (2 years old, black circles), BO3 (12 years old, low water use, red circles), PTPN6 (12 years old, high water use, blue circles) and HAR_old (25 years old, green circles). Significant linear relationships are indicated with solid $(P<0.05)$ and dotted $(P<0.1)$ lines, regression functions are provided in the figure.

Figure 4.6 Normalized diurnal pattern of vapor pressure deficit (VPD), radiation $\left(R_{\mathrm{g}}\right)$, transpiration $(T)$ and evapotranspiration $\left(E_{\mathrm{T}}\right)$ in a 2-year-old (PA) (a) and a 12year-old (PTPN6) (c) oil palm stand; absolute hourly values of $E_{\mathrm{T}}$ and $T$ in PA (b) and PTPN6 (d). Eddy covariance and sap flux density measurements were conducted in parallel to derive evapotranspiration and transpiration rates, respectively. Values of three sunny days averaged.

Figure 5.1 Locations of the 10 studied rubber plantations in Jambi province, Sumatra, Indonesia.

Figure 5.2 (a) Sap flux densities derived from gravimetric measurements $\left(J_{\mathrm{s}_{-} \text {grav }}\right)$ and 83 thermal dissipation probes $\left(J_{\mathrm{S}_{-} \text {TDP }}\right)$ using the original calibration equation (Granier, 1985) and pooled data from five rubber segments. (b) Changes of normalized $J_{\mathrm{s}}$ with increasing sapwood depth as measured by heat field deformation sensors on five rubber trees. Absolute daysum $J_{\mathrm{s}}$ from all measurement depths and trees were normalized by the mean value of the five 
trees at the center of TDP sensors. For each tree, the daysum $J_{\mathrm{s}}$ values of at least 10 days were averaged; the line represents a Gaussian fit. (c) Daily rubber tree water use derived from TDP vs. stem heat balance (SHB) measurements. TDP measurement were extrapolated to plant water use based on radial profile measurements. Pooled data from four trees, with at least two weeks of measurements per tree.

Figure 5.3 Sap flux density $\left(J_{s_{-} \max }\right)$ (a) and tree water use (b) in five mature rubber plantations when fully in leaves. Each point represents the mean value of three sunny days; solid points represent trees in relatively young rubber plantations (7-8 yrs), hollow ones trees in older plantations (14-16 yrs).

Figure 5.4 Average tree water use of fully-leaved rubber plantations $(n=7)$ with varying plantation age. Each point represents the mean tree water use of three selected sunny days; the error bars represent the according standard errors. A negative exponential function was fitted to the average tree water use values; the according $R^{2}$ adj and $P$-values are provided in the figure.

Figure 5.5 Normalized tree water use of different rubber plantations measured during the fully-leaved $(\mathrm{n}=5)$ and partially-leaved $(\mathrm{n}=4)$ period, respectively. Normalization occurred by dividing average water use values of each plantation by the mean tree water use of all plantations measured during the fully-leaved period. Each point represents the mean tree water use of three selected sunny days, the error bars represent the according standard errors.

Figure 5.6 Rubber tree water use plotted against average daytime vapor pressure deficit (VPD) (a) and integrated daily radiation $\left(R_{\mathrm{g}}\right)(\mathrm{b})$. Tree water use rates derived from 10 trees measured in the long-term monitoring plot (BR3). Solid points represent days during the fully-leaved period, hollow points during the partially-leaved period. The solid lines represent the linear regressions during the fully-leaved period, dashed lines indicate the fitting during the partiallyleaved period. According $R^{2}$ and $P$-values are provided in the panels.

Figure 5.7 Normalized hourly tree water use rates plotted against normalized hourly vapor 87 pressure deficit (VPD) (a) and radiation $\left(R_{\mathrm{g}}\right)(\mathrm{b})$ on three selected sunny and cloudy days during the fully-leaved period. Data were normalized by setting the respective diurnally observed maximum values to one. The normalized tree water use rates were the average of all sample trees in the long-term monitoring plot (BR3). The arrows indicate the order of observations, the numbers the respective times of day.

Figure 6.1 The diurnal courses of palm/tree water use in the oil palm and rubber long-term 100 monitoring plots (BO3 and BR3). Points represent hourly average values. Data come from one typical sunny day (daytime average $\mathrm{VPD}=1.65 \mathrm{kPa}$; daily summed radiation $=20.4 \mathrm{MJ} \mathrm{m}^{-2} \mathrm{~d}^{-1}$ ) and one cloudy day (daytime average $\mathrm{VPD}=0.55 \mathrm{kPa}$; daily summed radiation $\left.=7.9 \mathrm{MJ} \mathrm{m}^{-2} \mathrm{~d}^{-1}\right)$.

Figure 6.2 Palm/tree water use (both absolute and normalized values) plotted against 102 vapor pressure deficit (VPD, absolute and normalized values) on one typical 
sunny day (daytime average $\mathrm{VPD}=1.65 \mathrm{kPa}$; daily summed radiation $=20.4$

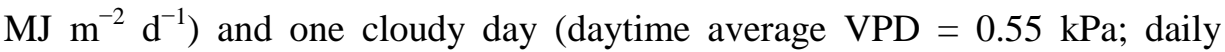
summed radiation $=7.9 \mathrm{MJ} \mathrm{m}^{-2} \mathrm{~d}^{-1}$ ). Data for rubber trees were from fullyleaved period. Points represent hourly averaged values. Arrows indicate the direction in which the next consecutive observation in time occurred.

Figure 6.3 Normalized stand transpiration rates in the oil palm and rubber long-term monitoring plots (BO3 and BR3) plotted against VPD. Data for rubber plantations were from the fully-leaved period. Transpiration rates are daily averages, VPD data are daytime averages.

Figure 6.4 Seasonal changes of normalized transpiration (a) and VPD, radiation and 104 precipitation (b) in the oil palm and rubber long-term monitoring plots (BO3 and BR3). Data from 13 June to 10 August 2013. Transpiration rates were normalized by setting the respective maxima during the study periods to one. VPD data are daytime averages, radiation data are presented as daysums.

Figure 6.5 The palm/tree water use (a) and stand transpiration (b) plotted against stand 105 ages in oil palm and rubber plantations. The presented data are averages of three sunny days. Data for rubber plantations are all from fully-leaved periods.

Appendix The change of maximum hourly sap flux density (a), average leaf water use

Figure 4.1 (b), average palm water use (c) and stand transpiration (d) over stand age. Data of the different levels derived from simultaneous sap flux measurements on at least 13 leaves per stand; values of three sunny days averaged. The provided fits are Hill functions (dotted lines). 


\section{INDEX OF TABLES}

Table 4.1 Stand locations, characteristics and study periods. Pg.

Table 4.2 Summary table of results for all 15 oil palm stands. $R^{2}$ and $P$ values for linear regression and fitting a Hill function, respectively, are presented to explain variability in water use characteristics (i.e. maximum sap flux density, leaf water use, palm water use and stand transpiration) by the stand variables age, trunk height and sapwood area.

Table 4.3 Summary table of results for 12 oil palm stands, i.e. excluding three stands of yet unexplained much higher water use (PTPN6, BO5, and HO2). $R^{2}$ and $P$ values for linear regression and fitting a Hill function, respectively, are presented to explain variability in water use characteristics (i.e. maximum sap flux density, leaf water use, palm water use and stand transpiration) by the stand variables age, trunk height and sapwood area.

Table 5.1 Geography and climate, and stand characteristics in the studies from the Asian mainland and this study on Sumatra.

Appendix Detailed stand characteristics and transpiration rates $(T)$ in the 10 rubber 


\section{ACKNOWLEDGEMENTS}

First of all, I would like to thank my PhD advisor Prof. Dr. Dirk Hölscher for his attentive, inspiring, and endless help through last four years. It would not have been possible to complete this dissertation without his advice and guidance!

I want to thank Eva Siegelkow, for her professional administrative support. And also thanks to all administrative people in "EFForTS" project, Wolfram Lorenz, Dr. Bambang Irawan, Rizky, Mega, Yuking, and others, for your help and support during my field work.

I would like to thank colleagues from Tropical Silviculture and Forest Ecology, in particular, Dongming Fang and Tingting Mei who teach me the sap flux techniques, and Alexander Röll for the incredible and fruitful teamwork from the field work to the publication process, and also big thanks for correcting my "chinglish" and English-German translation! It has been a great pleasure to work with you! And also thanks to Afik Hardanto for his great support during the field work. Terima kasih!

Thanks to colleagues from "EFForTS" project, Ana Meijide, Yuanchao Fan, Martyna Malgorzata Kotowska, Clifton Sabajo, Andrea Hanf, and others, for sharing data and all kinds of help. A special thanks to our field assistants Bayu and Ferry, it would not have been possible to complete the field work without your help!

I am grateful to "China Scholarship Council (CSC)" for providing me funding for PhD study in Germany. And also thanks my advisor Prof. Dr. Dirk Hölscher for providing me half year scholarship to finalize my PhD study. The "EFForTS" project which funded by DFG provided travel cost and logistic support for the field work also deserves big thanks.

Last but not least, I would like to thank my parents, my siblings, my friends, and Miss Di Yang, all of you support and encourage me all the time! 


\section{DECLARATION OF HONOR}

I hereby declare that I am the sole author of this dissertation entitled "TRANSPIRATION BY OIL PALM AND RUBBER PLANTATIONS: REFINING METHODS AND DELINEATING DIFFERENCES" and that all references and data sources have been acknowledged as such. I further declare that this work has never been submitted in any form as part of any other dissertation procedure.

Göttingen, July 2016,

(Furong Niu) 


\section{CURRICULUM VITAE}

Name

Date of birth

Place of birth

Citizenship

\section{Education}

2005-2009

2009-2012

2012-present

\section{Furong Niu}

18.06.1987

Gansu, China

Chinese

B.Sc. in Biology, Faculty of Life Sciences, Mudanjiang Normal University, China

M.Sc. in Ecology, College of Forestry (Academy of Forestry), Northwest A\&F University, China

Ph.D. in Forest Sciences and Forest Ecology, Tropical Silviculture and Forest Ecology, Georg-August-Universität Göttingen, Germany

\section{List of Publications}

Niu, F.*, Röll, A.*, Hardanto, A., Meijide, A., Hendrayanto, Hölscher, D. Oil palm water use: calibration a sap flux method and a field measurement scheme. Tree Physiology (2015) 35: 563-573, doi: 10.1093/treephys/tp-v013.

Röll, A.*, Niu, F.*, Meijide, A., Hardanto, A., Hendrayanto, Knohl, A., Hölscher, D. Transpiration in an oil palm landscape: effects of palm age. Biogeosciences (2015) 12: 5619-5633, doi: 10.5194/bg-12-5619-2015.

\section{Conference presentations}

Niu, F., Röll, A., Hardanto, A., Hanf, A., Hendrayanto, Junedi, H., Köhler, M., Hölscher, D. Water use of oil palms: calibration of a sap flux method and first results. Poster presentation. GfÖ 2014, Hildesheim, Germany.

Niu, F., Röll, A., Hardanto, A., Meijide, A., Junedi, H., Herdhata, A., Hendrayanto, Knohl, A., Hölscher, D. Transpiration in an oil palm landscape: effects of palm age. Oral presentation. ATBC 2015, Honolulu, USA.

Röll, A., Niu, F. (presenter), Hardanto, A., Meijide, A., Hendrayanto, Knohl, A., Hölscher, D. Transpiration changes by transforming tropical rainforest to rubber and oil palm plantations. Oral presentation. GTÖ 2016, Göttingen, Germany. 
